\title{
Stereoselective cyclopropanation of electrondeficient olefins with a cofactor redesigned carbene transferase featuring radical reactivity.
}

Daniela M. Carminati ${ }^{a}$ and Rudi Fasan*,a

${ }^{a}$ Department of Chemistry, University of Rochester, 14627 Rochester, New York, USA

Correspondence should be addressed to R.F. (rfasan@ur.rochester.edu)

Table of Contents

Supplementary Tables S1-S3

Pages S2-S4

Supplementary Figures S1-S9

Pages S5-S32

Experimental Procedures

Pages S37-S39

Compound Characterization Data

Pages S39-S49

NMR spectra

Pages S50-53

References

Page S54 
Table S1. Cyclopropanation of styrene with EDA catalyzed by Mb-variants.

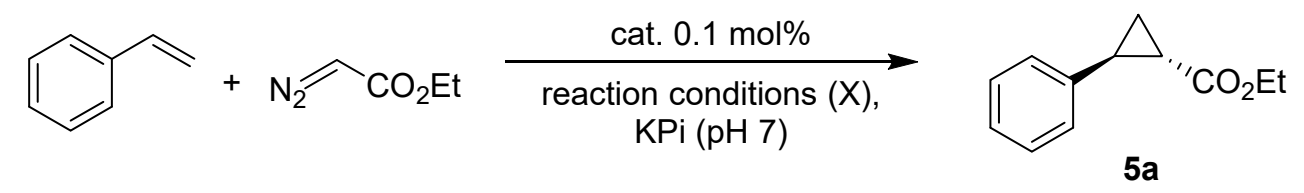

\begin{tabular}{cccccc}
\hline Entry & Catalyst & $\mathrm{X}^{[\mathrm{a}]}$ & Yield (TON) & $\%$ de & $\%$ ee \\
\hline 1 & $\mathrm{Mb}(\mathrm{H} 64 \mathrm{~V}, \mathrm{~V} 68 \mathrm{~A}, \mathrm{H} 93 \mathrm{NMH})$ & $-/ \mathrm{red}$ & $93 \%(930)$ & $>99$ & 95 \\
2 & $\mathrm{Mb}(\mathrm{H} 64 \mathrm{~V}, \mathrm{~V} 68 \mathrm{~A}, \mathrm{H} 93 \mathrm{NMH})$ & $-/-$ & $94 \%(937)$ & $>99$ & 99 \\
3 & $\mathrm{Mb}(\mathrm{H} 64 \mathrm{~V}, \mathrm{~V} 68 \mathrm{~A}, \mathrm{H} 93 \mathrm{NMH})$ & $\mathrm{O}_{2} / \mathrm{red}$ & $63 \%(629)$ & $>99$ & 98 \\
4 & $\mathbf{1}$ & $\mathrm{O}_{2} /-$ & - & - & - \\
5 & $\mathbf{2}$ & $\mathrm{O}_{2} /-$ & $0.4 \%(4.4)$ & $>99$ & $>99$ \\
6 & $\mathrm{Mb}(\mathrm{H} 64 \mathrm{~V}, \mathrm{~V} 68 \mathrm{~A}, \mathrm{H} 93 \mathrm{NMH})$ & $\mathrm{O}_{2} /-$ & $14 \%(141)$ & $>99$ & $>99$ \\
7 & $\mathrm{Mb}(\mathrm{H} 64 \mathrm{~V}, \mathrm{~V} 68 \mathrm{~A}, \mathrm{H} 93 \mathrm{NMH})$ & $\mathrm{CO}$ & $1 \%(14)$ & $>99$ & $>99$ \\
8 & $\mathbf{3}$ & $\mathrm{CO}$ & $2 \%(18)$ & $>99$ & $>99$ \\
\hline
\end{tabular}

Reaction conditions: $10 \mathrm{mM}$ styrene, $20 \mathrm{mM}$ EDA, $10 \mu \mathrm{M}$ purified $\mathrm{Mb}$ variant in $\mathrm{KPi} 50 \mathrm{mM}$ (pH 7), at $400 \mu \mathrm{L}$-scale, RT, 16 hours. Yield, diastereomeric and enantiomeric excess determined by chiral GC-FID analysis using 1,3-benzodioxole as internal standard. [a] Variable parameter (X): “/red"=anaerobic, $10 \mathrm{mM} \mathrm{Na}_{2} \mathrm{~S}_{2} \mathrm{O}_{4}$; “-/_“"=anaerobic, no reductant; " $\mathrm{O}_{2} /$ red"=aerobic, $10 \mathrm{mM} \mathrm{Na} \mathrm{S}_{2} \mathrm{O}_{4}$; "O $\mathrm{O}_{2} /$-"=aerobic, no reductant; " $\mathrm{CO} "=$ under $\mathrm{CO}$, no reductant. 
Table S2. Cyclopropanation of 4-vinyl-benzensulfonamide with EDA.

\begin{tabular}{|c|c|c|c|c|}
\hline Entry & Catalyst & Yield (TON) & $\% d e$ & $\%$ ee \\
\hline $1^{a}$ & $\mathrm{Rh}_{2}(\mathrm{OAc})_{4}$ & - & - & - \\
\hline $2^{a}$ & $\mathrm{Fe}(\mathrm{TPP}) \mathrm{Cl}$ & - & - & - \\
\hline 3 & 1 & $2 \%(10)$ & $>99$ & $>99$ \\
\hline 4 & 2 & $2 \%(10)$ & $>99$ & $>99$ \\
\hline 5 & Mb(H64V,V68A,H93NMH) & $20 \%(120)$ & $>99$ & 88 \\
\hline 6 & 3 & $48 \%(240)$ & $>99$ & 85 \\
\hline
\end{tabular}

Reaction conditions: $20 \mathrm{mM}$ alkene, $10 \mathrm{mM}$ EDA, $20 \mu \mathrm{M}$ purified $\mathrm{Mb}$ variant in $\mathrm{KPi} 50 \mathrm{mM}$ (pH 7), at $400 \mu \mathrm{L}$-scale, RT, 16 hours. Yield, diastereomeric excess determined by chiral GC-FID analysis using 1,3-benzodioxole as internal standard. Enantiomeric excess determined by SFC. ${ }^{a}$ Reaction was carried out with $2 \mathrm{~mol} \%$ of catalyst, 5 eq alkene, 1 eq EDA in DCM under argon at RT for 24 hours. 
Table S3. Cyclopropanation of vinylbenzoate with EDA.

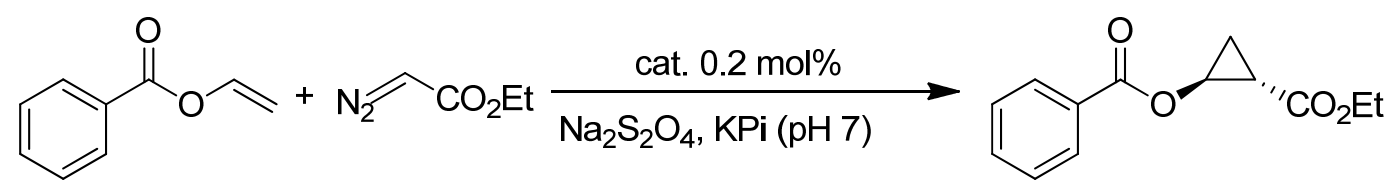

\begin{tabular}{ccccc}
\hline Entry & Catalyst & Yield (TON) & $\%$ de & $\%$ ee \\
\hline $1^{a}$ & $\mathrm{Rh}_{2}(\mathrm{OAc})_{4}$ & $25 \%$ & 55 & - \\
$2^{a}$ & $\mathrm{Fe}(\mathrm{TPP}) \mathrm{Cl}$ & - & - & - \\
3 & $\mathbf{1}$ & - & - & - \\
4 & $\mathbf{2}$ & $2 \%(10)$ & $>99$ & 99 \\
5 & $\mathrm{Mb}(\mathrm{H} 64 \mathrm{~V}, \mathrm{~V} 68 \mathrm{~A}, \mathrm{H} 93 \mathrm{NMH})$ & $10 \%(50)$ & $>99$ & 99 \\
6 & $\mathbf{3}$ & $>99 \%(483)$ & 99 & 97 \\
\hline
\end{tabular}

Reaction conditions: $2.5 \mathrm{mM}$ alkene, $2.5 \mathrm{mM}$ EDA, $5 \mu \mathrm{M}$ purified $\mathrm{Mb}$ variant in $\mathrm{KPi} 50 \mathrm{mM}(\mathrm{pH} 7)$, at $400 \mu \mathrm{L}$-scale, RT, 16 hours. Yield, diastereomeric excess determined by chiral GC-FID analysis using 1,3-benzodioxole as internal standard. Enantiomeric excess determined by SFC. ${ }^{a}$ Reaction was carried out with $2 \mathrm{~mol} \%$ of catalyst, 5 eq alkene, 1 eq EDA in DCM under argon at RT for 24 hours. 
Figure S1. UV-vis spectra of Mb(H64V,V68A) (1).

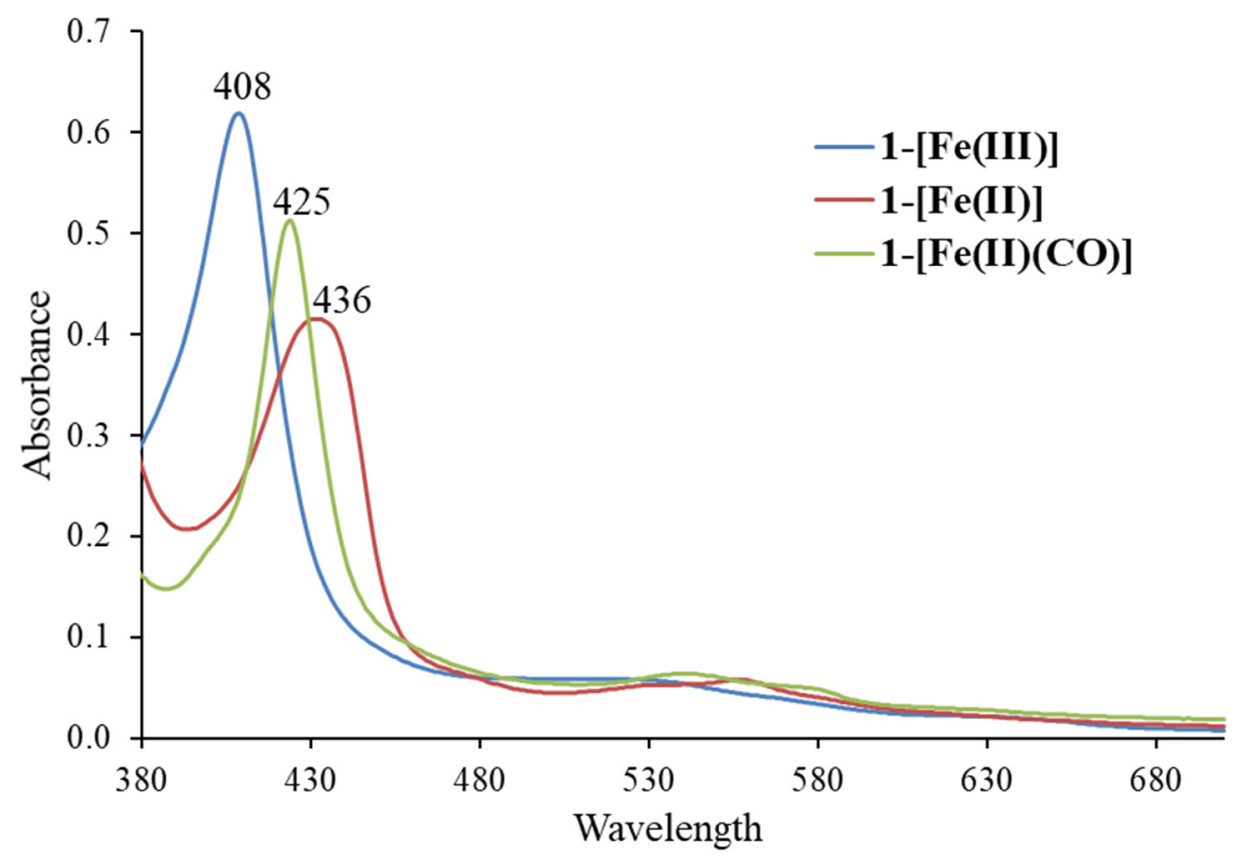


Figure S2. Thermal denaturation curves of $\mathrm{Mb}(\mathrm{H} 64 \mathrm{~V}, \mathrm{~V} 68 \mathrm{~A})[\mathrm{Fe}(\mathrm{DADP})]$

(2) (a) and $\mathrm{Mb}(\mathrm{H} 64 \mathrm{~V}, \mathrm{~V} 68 \mathrm{~A}, \mathrm{H} 93 \mathrm{NMH})[\mathrm{Fe}(\mathrm{DADP})]$ (3) (b).

a)

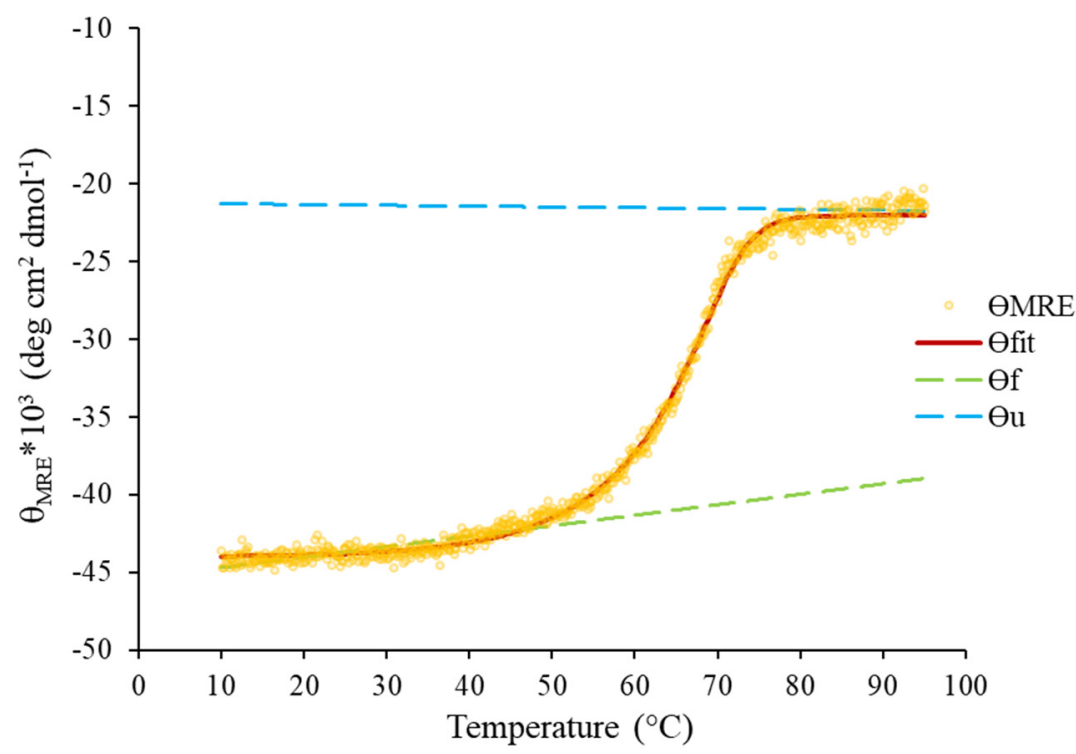

b)

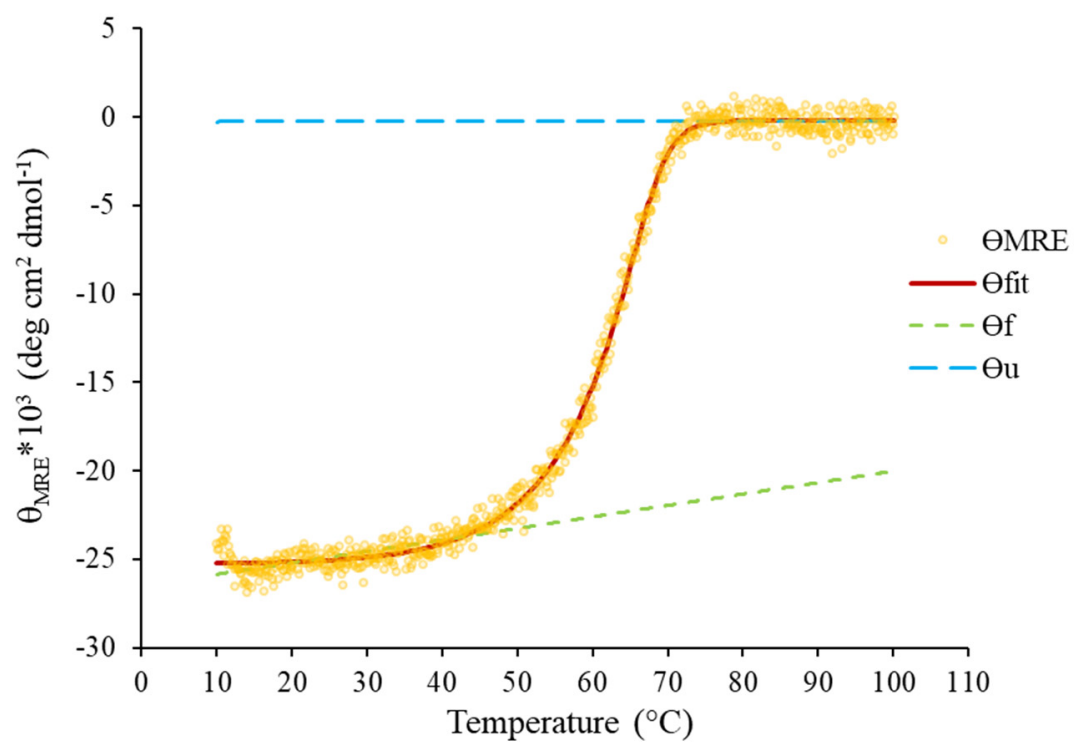


Figure S3. Redox potential determination of Mb variants. UV-vis spectra during the determination of the $\mathrm{Fe}^{3+/ 2+}$ reduction and Nerst plot.

a) $\mathrm{Mb}(\mathrm{H} 64 \mathrm{~V}, \mathrm{~V} 68 \mathrm{~A})$ (1) (Dye: Toluidine Blue):
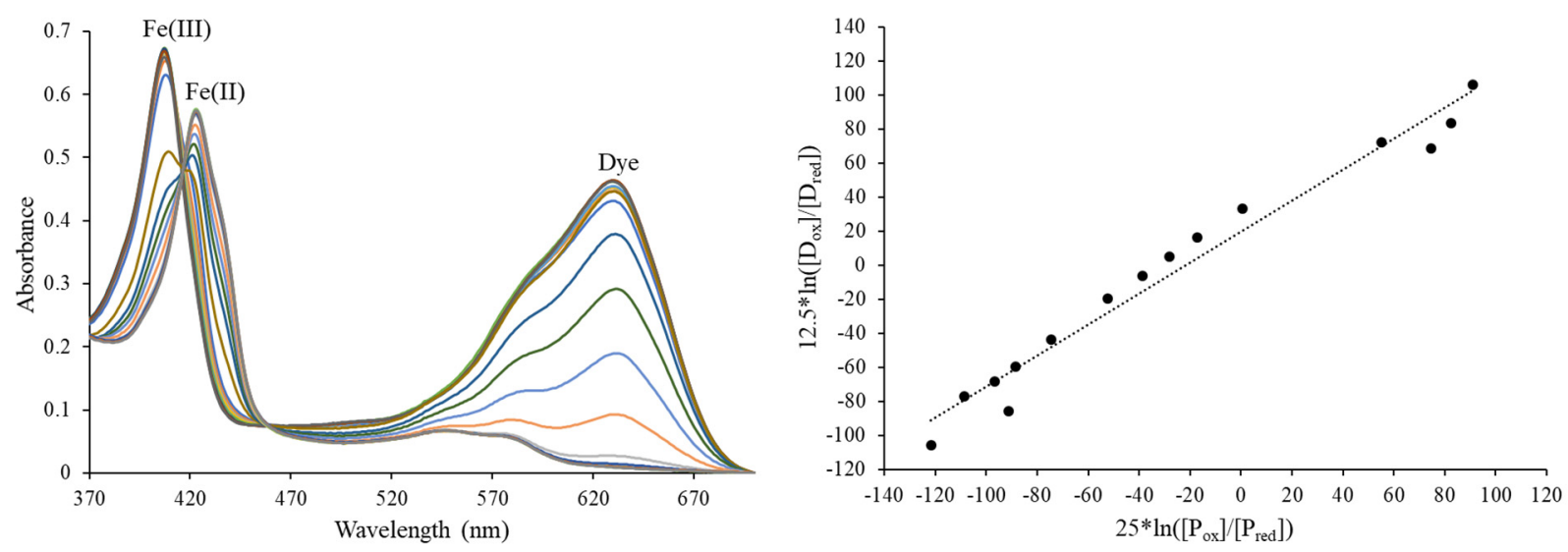

b) $\mathrm{Mb}(\mathrm{H} 64 \mathrm{~V}, \mathrm{~V} 68 \mathrm{~A}, \mathrm{H} 93 \mathrm{NMH})$ (Dye: Toluidine Blue):
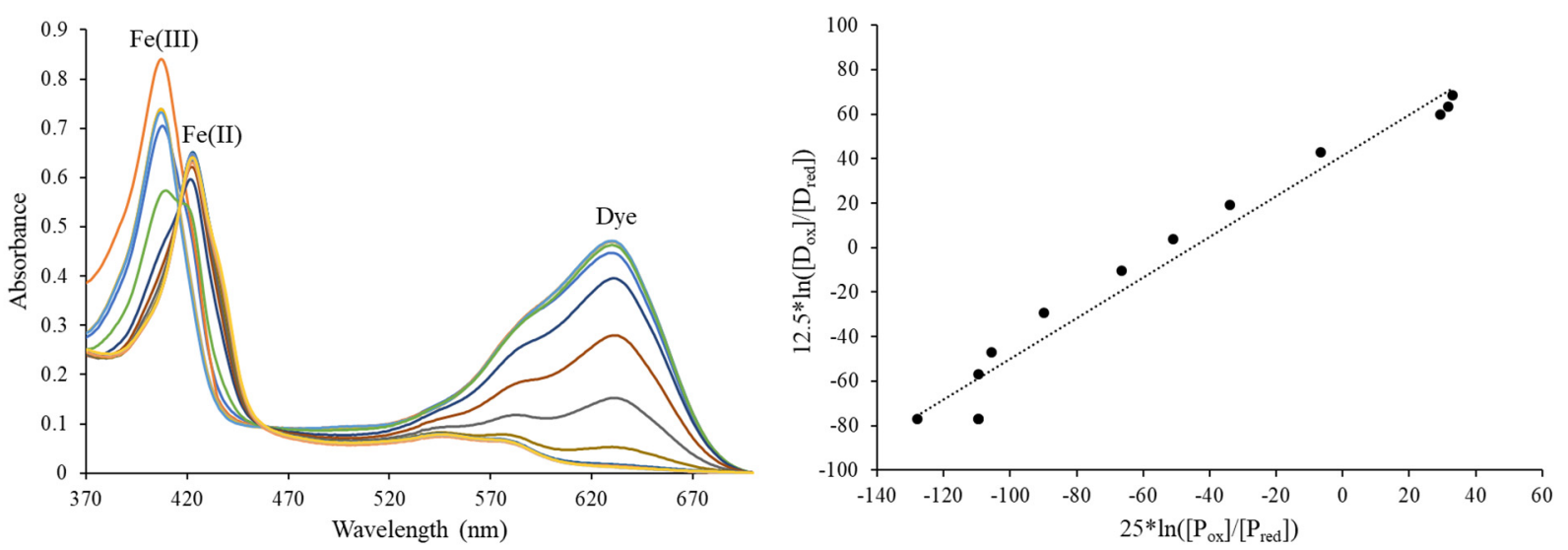

c) $\mathrm{Mb}(\mathrm{H} 64 \mathrm{~V}, \mathrm{~V} 68 \mathrm{~A}),[\mathrm{Fe}(\mathrm{DADP})]$ (2) (Dye: Toluidine Blue):
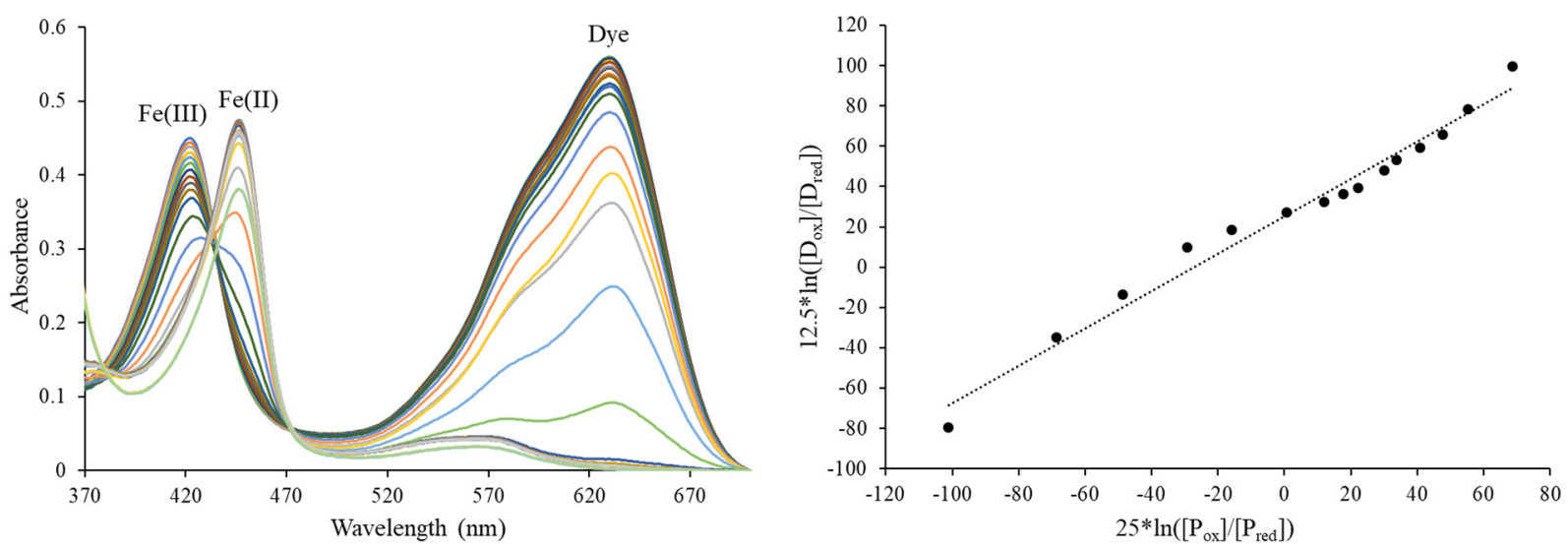
d) $\mathrm{Mb}(\mathrm{H} 64 \mathrm{~V}, \mathrm{~V} 68 \mathrm{~A}, \mathrm{H} 93 \mathrm{NMH})[\mathrm{Fe}(\mathrm{DADP})]$ (3) (Dye: Toluylene Blue):
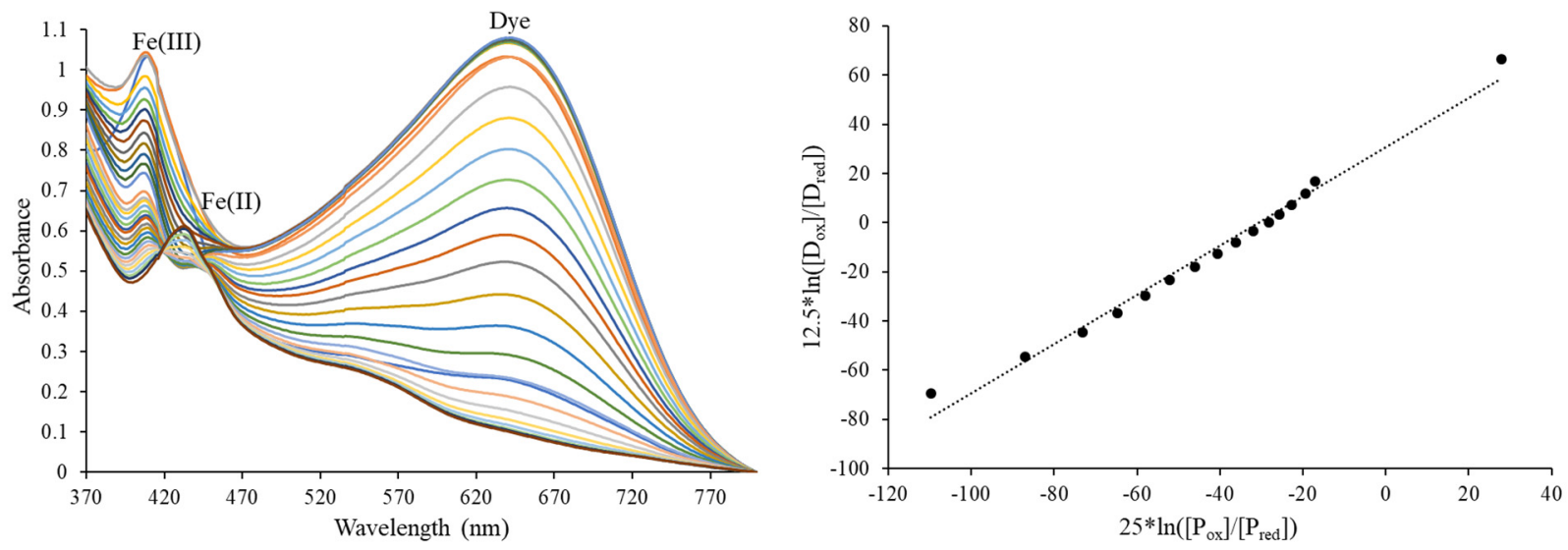
Figure S4. Electronic absorption spectra for ferric Mb-variants before and after incubation with $\mathrm{CO}$ at varying time points. Partial conversion $(<5 \%)$ to the ferrous and/or ferrous CO-bound form (shoulder at $420-438 \mathrm{~nm}$ ) is observed only after 60 min with $\mathbf{1}$ and $\mathbf{3}$.

a) $\mathrm{Mb}(\mathrm{H} 64 \mathrm{~V}, \mathrm{~V} 68 \mathrm{~A})(\mathbf{1})$ :

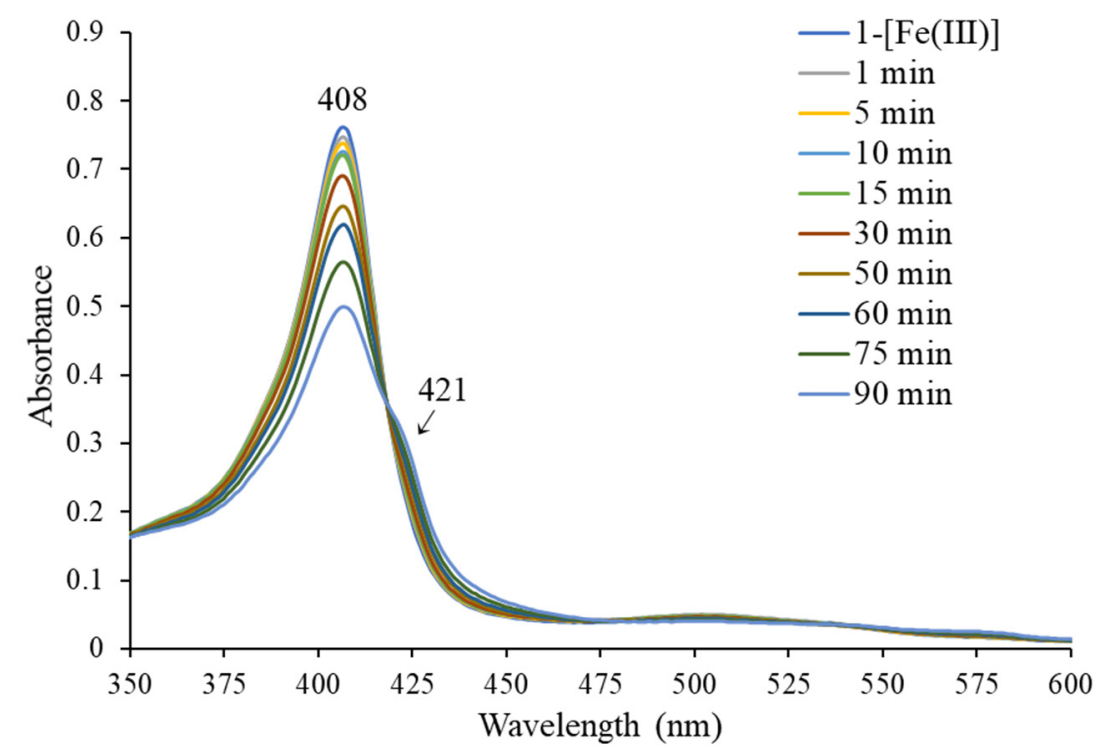

b) $\mathrm{Mb}(\mathrm{H} 64 \mathrm{~V}, \mathrm{~V} 68 \mathrm{~A})[\mathrm{Fe}(\mathrm{DADP})](2)$ :

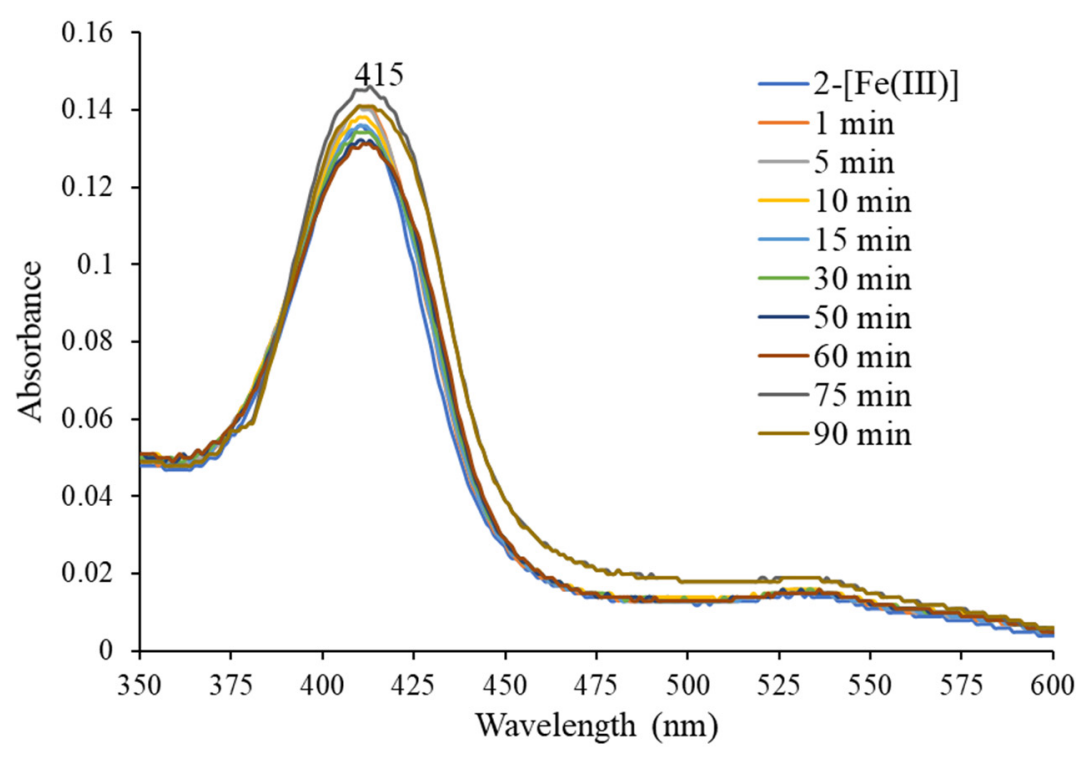


c) $\mathrm{Mb}(\mathrm{H} 64 \mathrm{~V}, \mathrm{~V} 68 \mathrm{~A}, \mathrm{H} 93 \mathrm{NMH})$ :

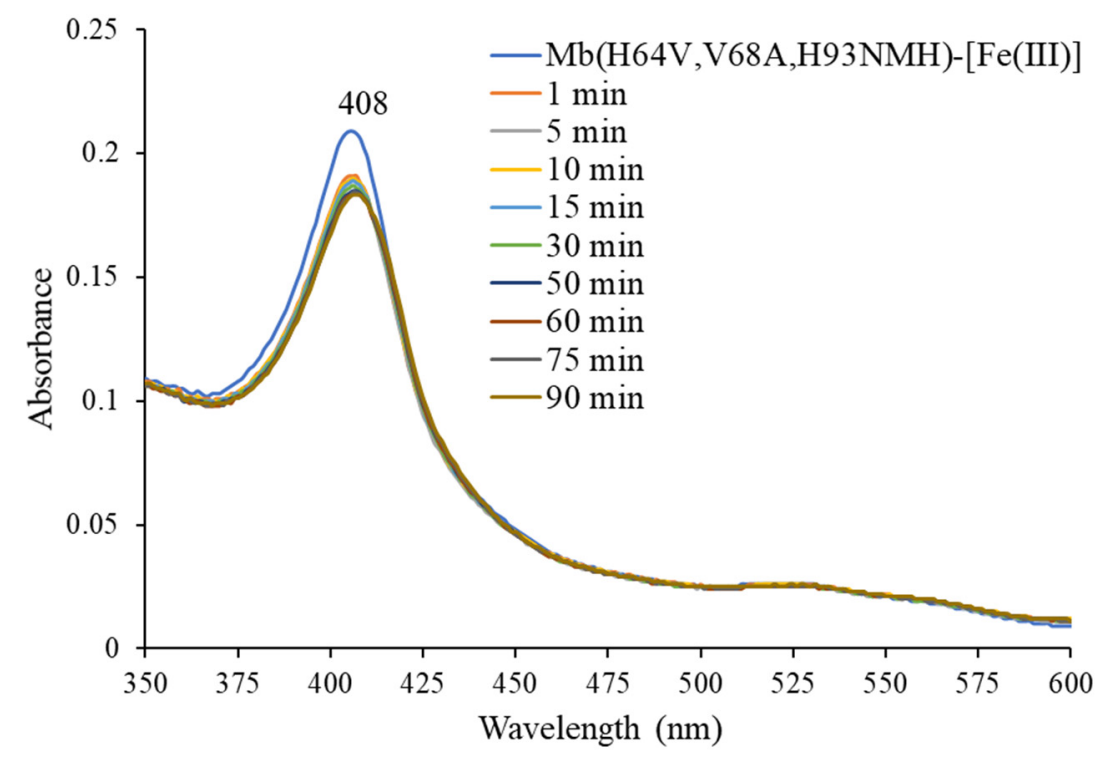

d) $\mathrm{Mb}(\mathrm{H} 64 \mathrm{~V}, \mathrm{~V} 68 \mathrm{~A}, \mathrm{H} 93 \mathrm{NMH})[\mathrm{Fe}(\mathrm{DADP})]$ (3):

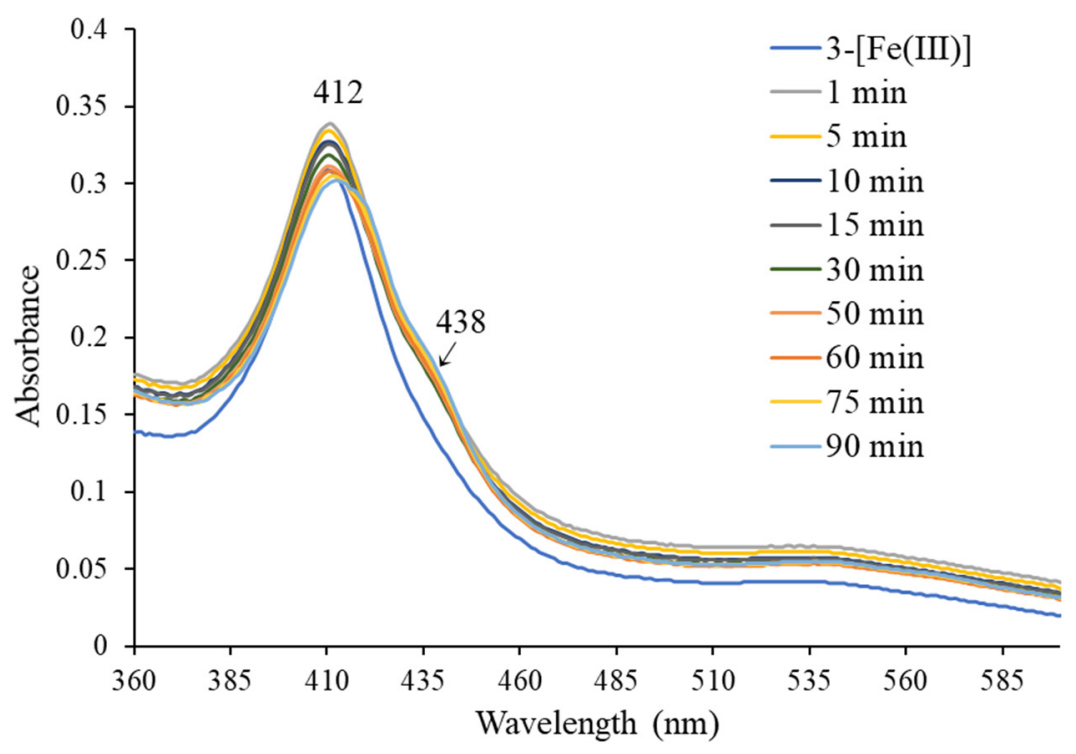


Figure S5. Kinetic plots for Mb(H64V,V68A,H93NMH)[Fe(DADP)]-catalyzed cyclopropanantion of vinyl benzoate and styrene.

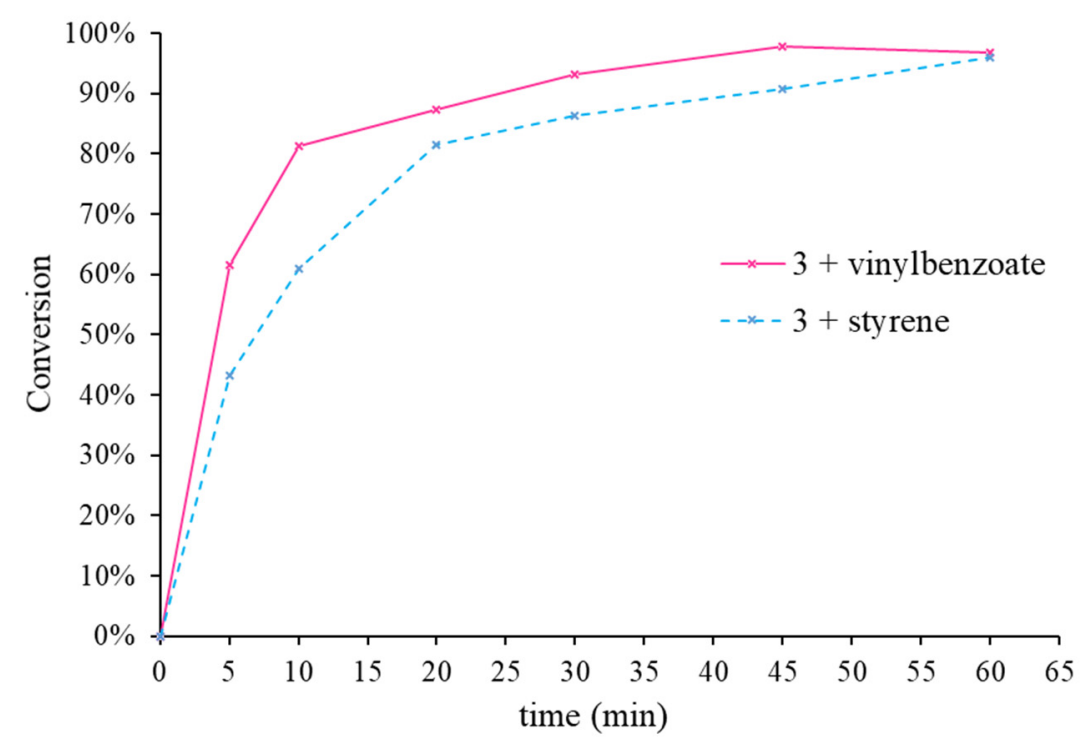


Figure S6. Kinetic plots for the $\mathrm{Mb}(\mathrm{H} 64 \mathrm{~V}, \mathrm{~V} 68 \mathrm{~A})$-catalyzed cyclopropanation of styrene ('H') and parasubstituted styrene ('X') in the presence of EDA. Reactions with $p$-methoxy-and $p$-methyl-styrenes were carried out using $1.5 \mu \mathrm{M}$ of protein (plots (a-b)). Reaction with $p$-chloro- and $p$-bromo-styrenes were carried out using $1 \mu \mathrm{M}$ of protein (plots (a-d)). Reactions with $p$-trifluoromethyl- and $p$-nitro-styrenes were carried out using $2 \mu \mathrm{M}$ of protein (plots (e-f)).
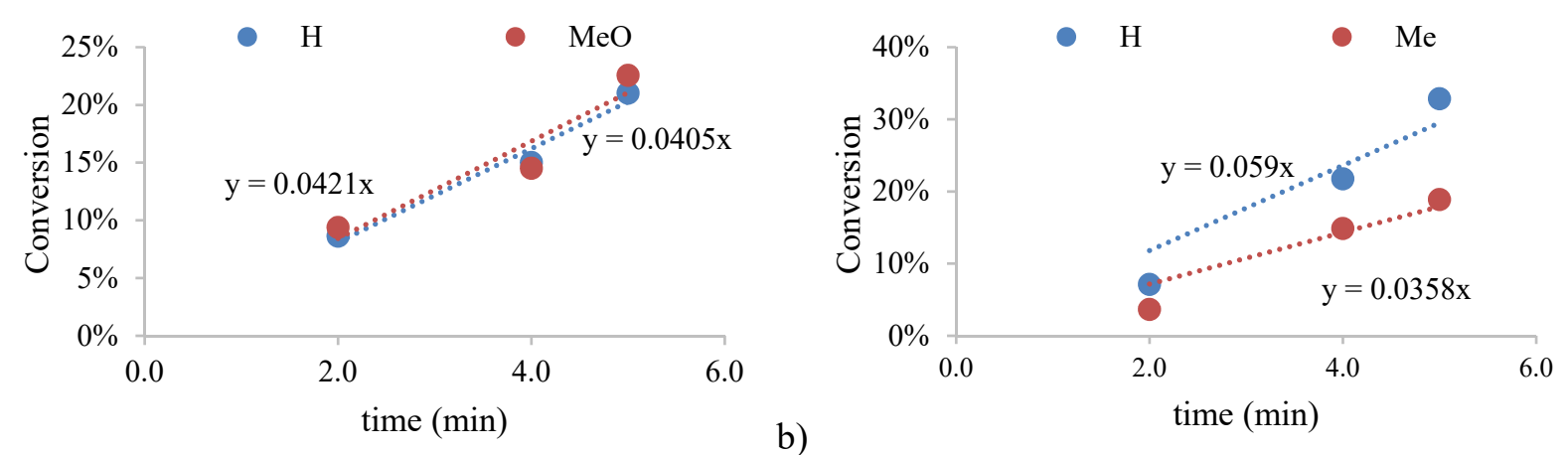

a)

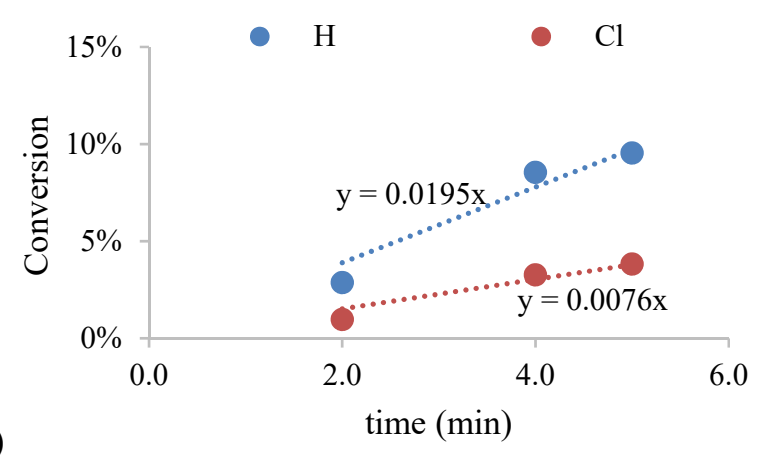

c)

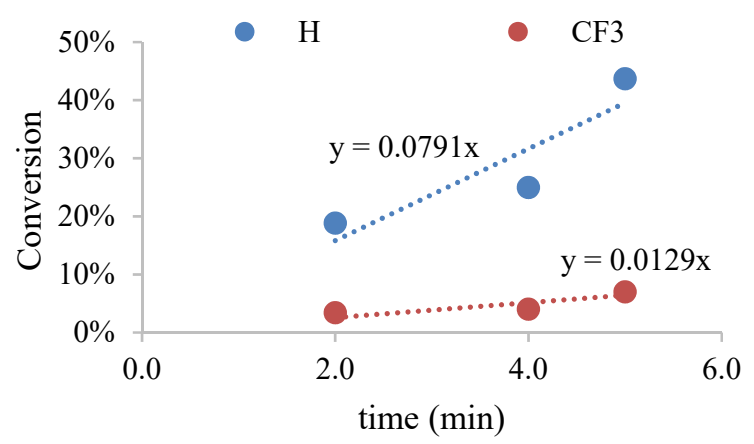

e)

f)
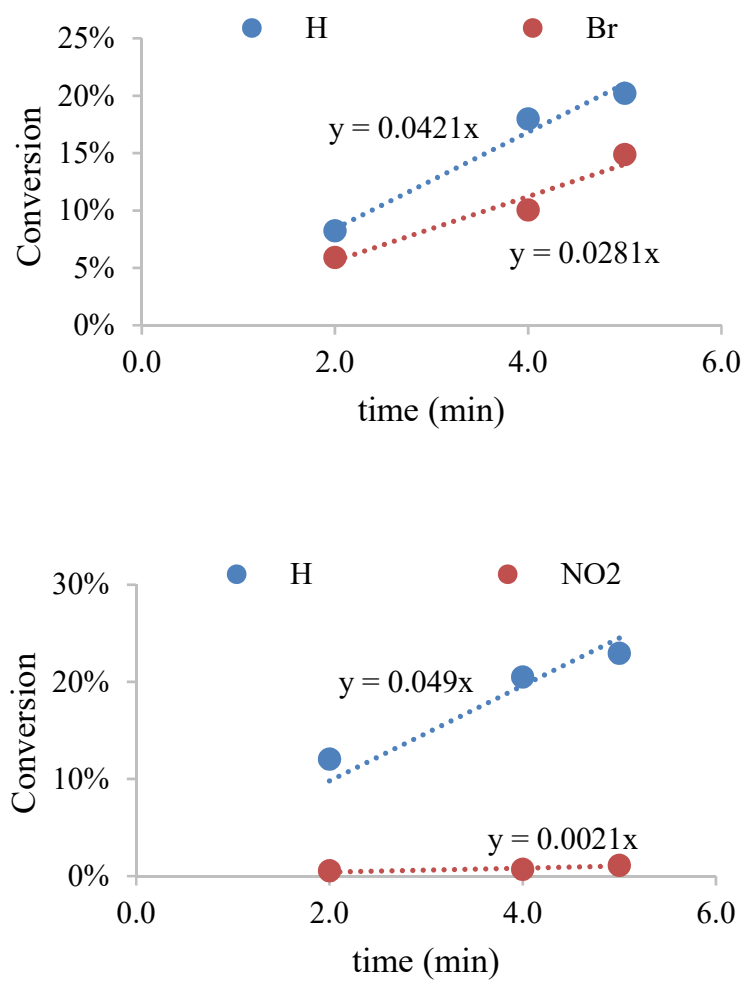
Figure S7. Kinetic plots for the Mb(H64V,V68A,H93NMH)[Fe(DADP)] (3)-catalyzed cyclopropanation of styrene ('H') and para-substituted styrene (' $\mathrm{X}$ ') in the presence of EDA. The reactions were carried out using $2 \mu \mathrm{M}$ of protein.

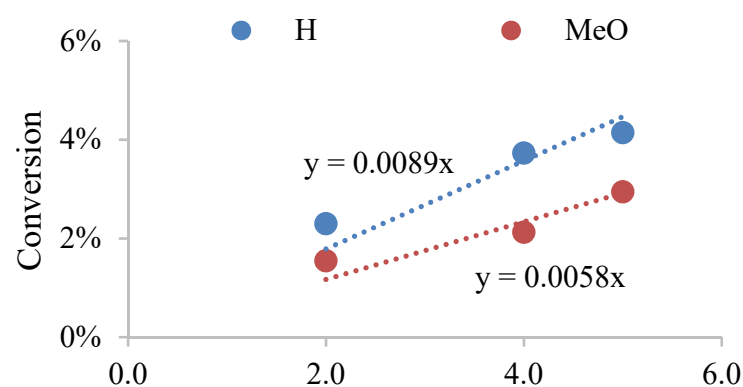

a)

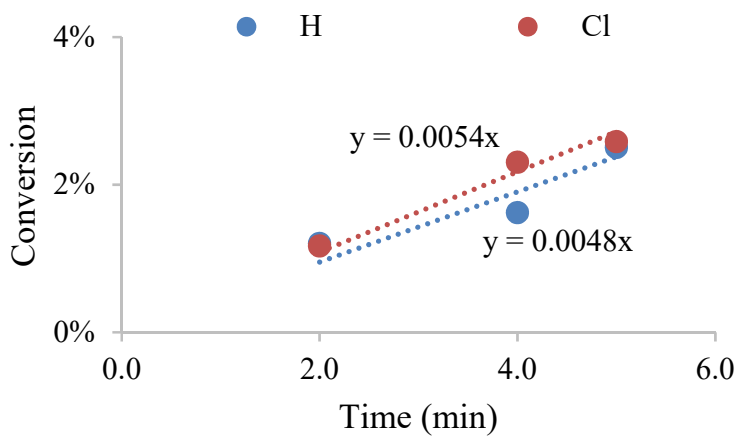

c)

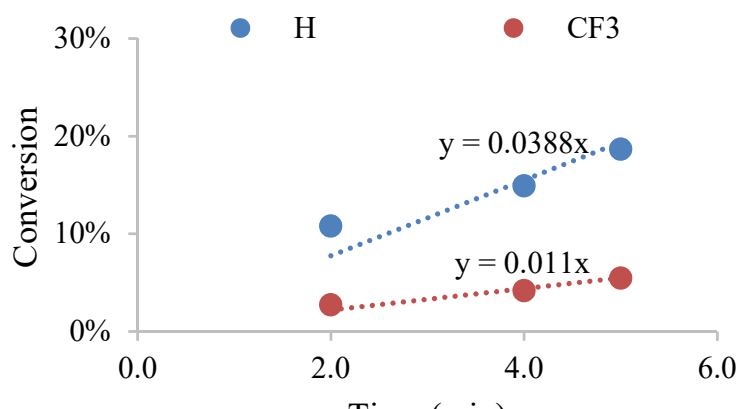

e)

Time (min)

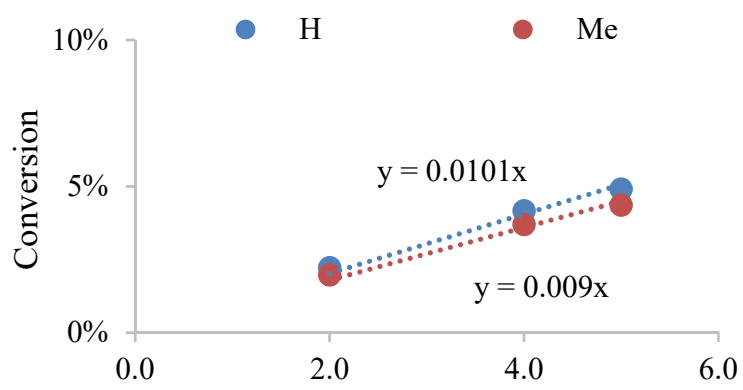

b)
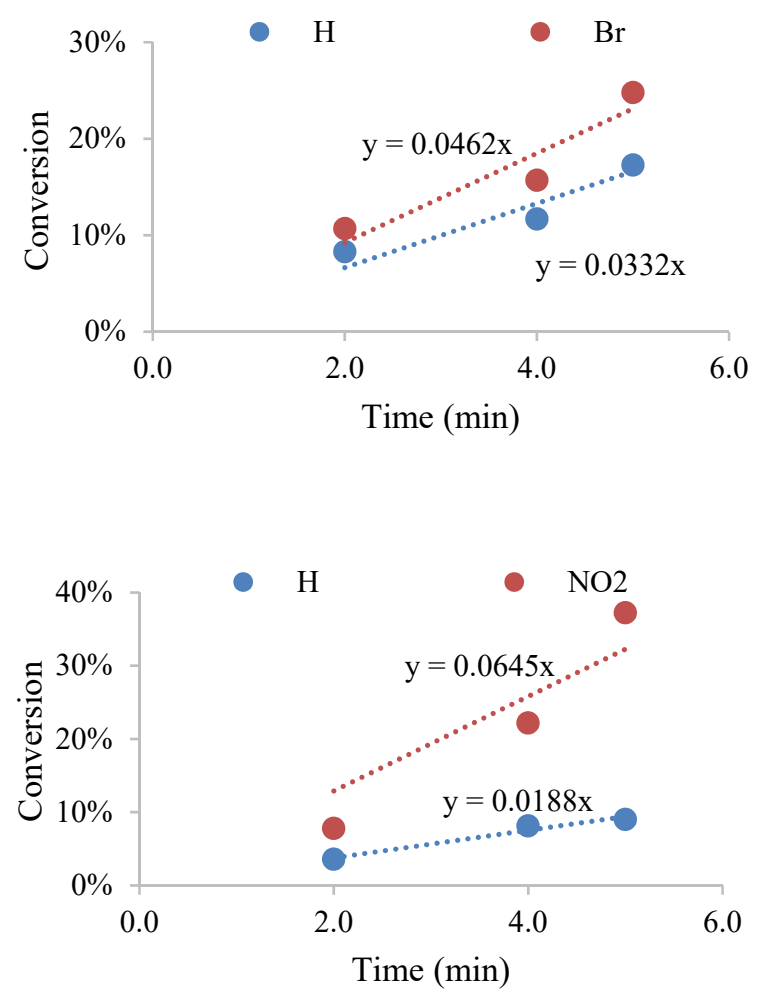
Figure S8. Chiral GC analyses for determination of diastereomeric excesses in the cyclopropanation reactions catalyzed by $\mathrm{Mb}(\mathrm{H} 64 \mathrm{~V}, \mathrm{~V} 68 \mathrm{~A}, \mathrm{H} 93 \mathrm{NMH})[\mathrm{Fe}(\mathrm{DADP})]$ (3). The reference racemic samples were prepared as described in the experimental procedures. Chiral GC analyses for compounds $\mathbf{5 a}, \mathbf{5 b}, \mathbf{5 c}, \mathbf{5 d}$, $\mathbf{5 e}, \mathbf{5 g}, \mathbf{5 h}, \mathbf{5 i}, \mathbf{5 j}$ and $\mathbf{5 n}$ were in accordance with those reported in literature. ${ }^{[1]}$

Chiral GC analysis of trans and cis isomers $\mathbf{5 b}$ (left) and enzymatically produced $\mathbf{5 b}$ product (right):
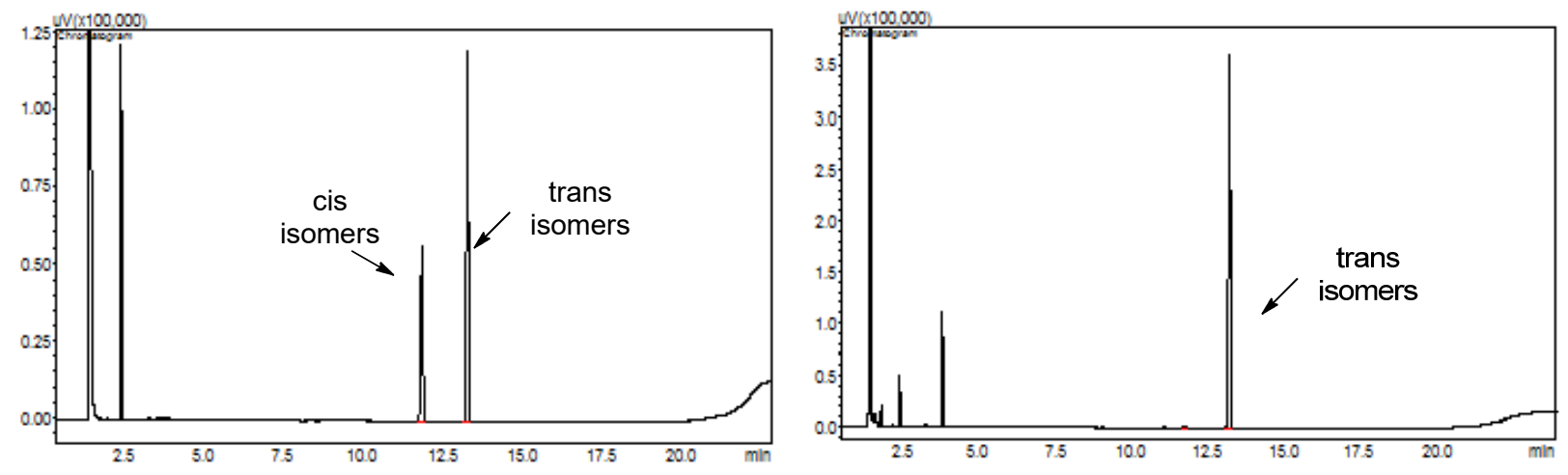

\begin{tabular}{ccc}
\hline Peak & Time & Area \\
\hline cis isomers & 11.6 & 2472 \\
trans isomers & 13.1 & 1408821
\end{tabular}

Chiral GC analysis of trans and cis isomers $\mathbf{5 c}($ left $)$ and enzymatically produced $\mathbf{5 c}$ product (right):
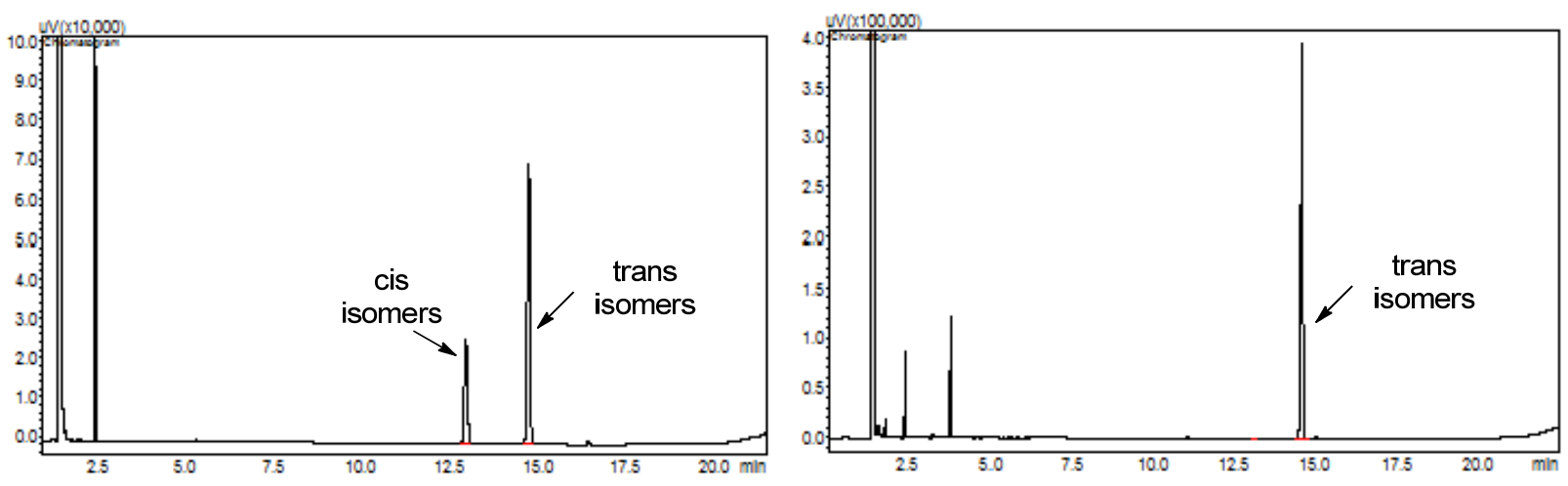

\begin{tabular}{ccc}
\hline Peak & Time & Area \\
\hline cis isomers & 13.1 & 16731 \\
trans isomers & 14.5 & 1761030 \\
\hline
\end{tabular}


Chiral GC analysis of trans and cis isomers $\mathbf{5 d}(l e f t)$ and enzymatically produced $\mathbf{5 d}$ product (right):

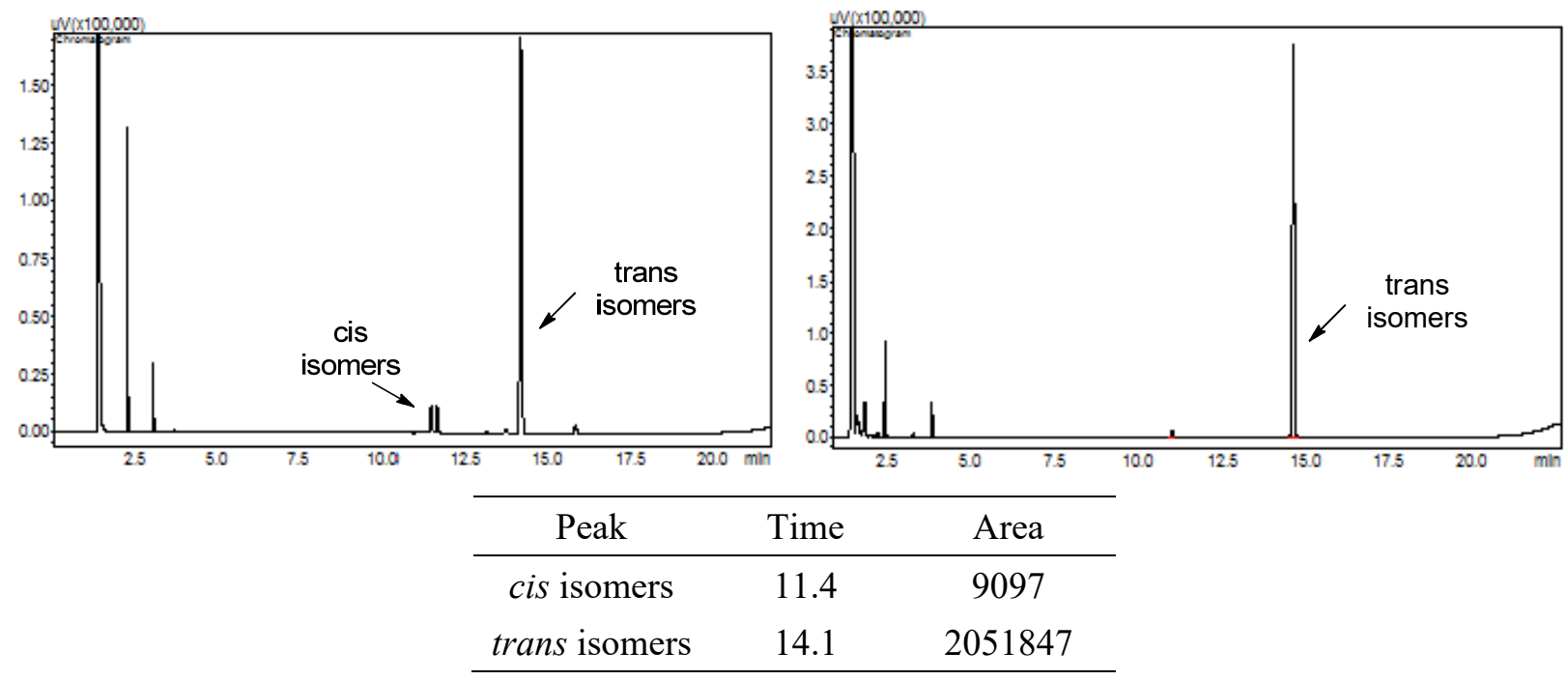

Chiral GC analysis of trans and cis isomers $\mathbf{5 e}($ left) and enzymatically produced $\mathbf{5 e}$ product (right):

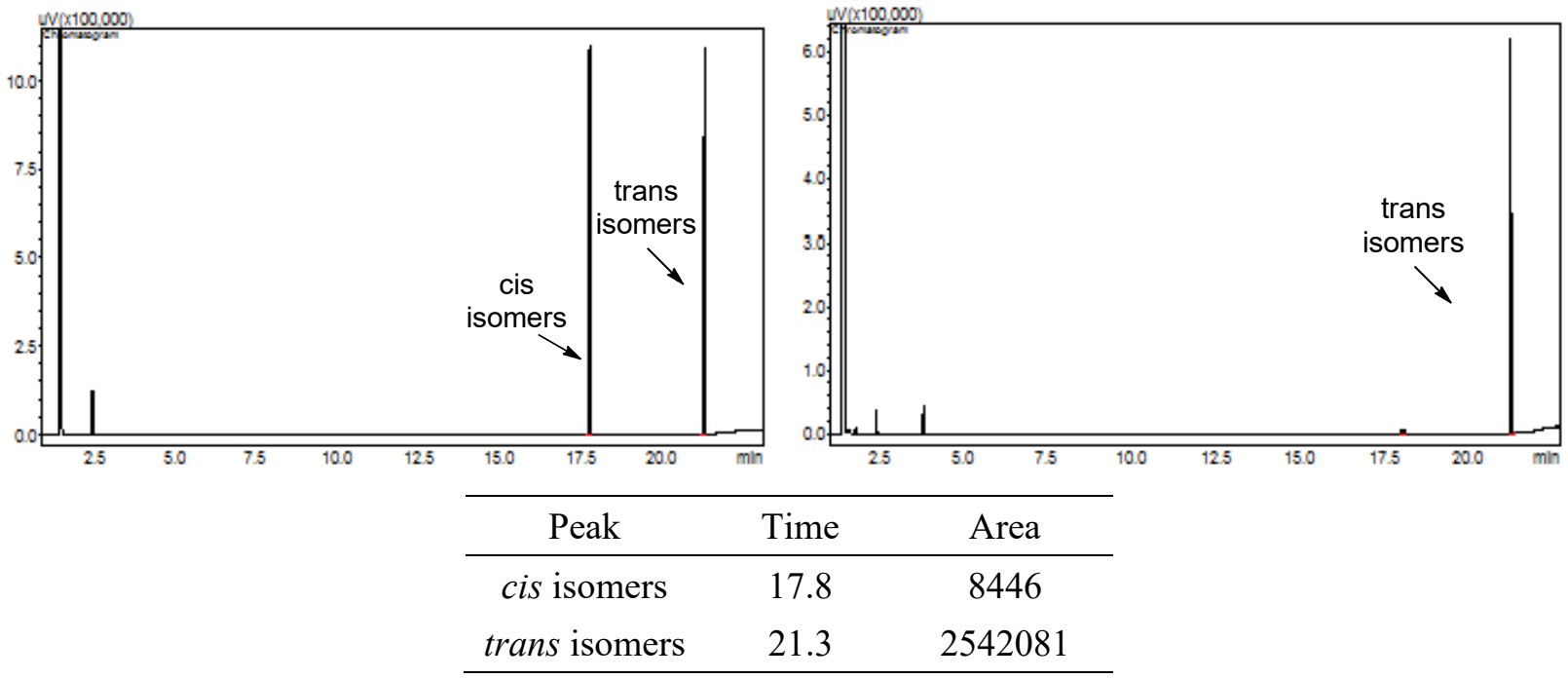


Chiral GC analysis of trans and cis isomers $\mathbf{5 f}($ left) and enzymatically produced $\mathbf{5 f}$ product (right):
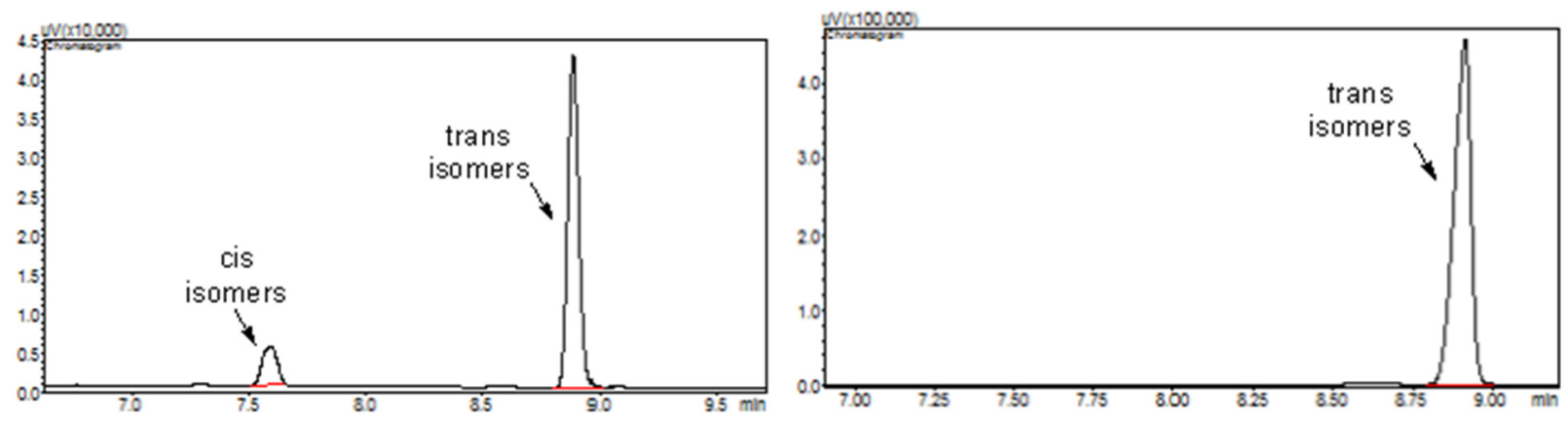

\begin{tabular}{ccc}
\hline Peak & Time & Area \\
\hline cis isomers & 7.6 & 1086 \\
trans isomers & 8.9 & 1701854
\end{tabular}

Chiral GC analysis of trans and cis isomers $\mathbf{5 g}$ (left) and enzymatically produced $\mathbf{5 g}$ product (right):
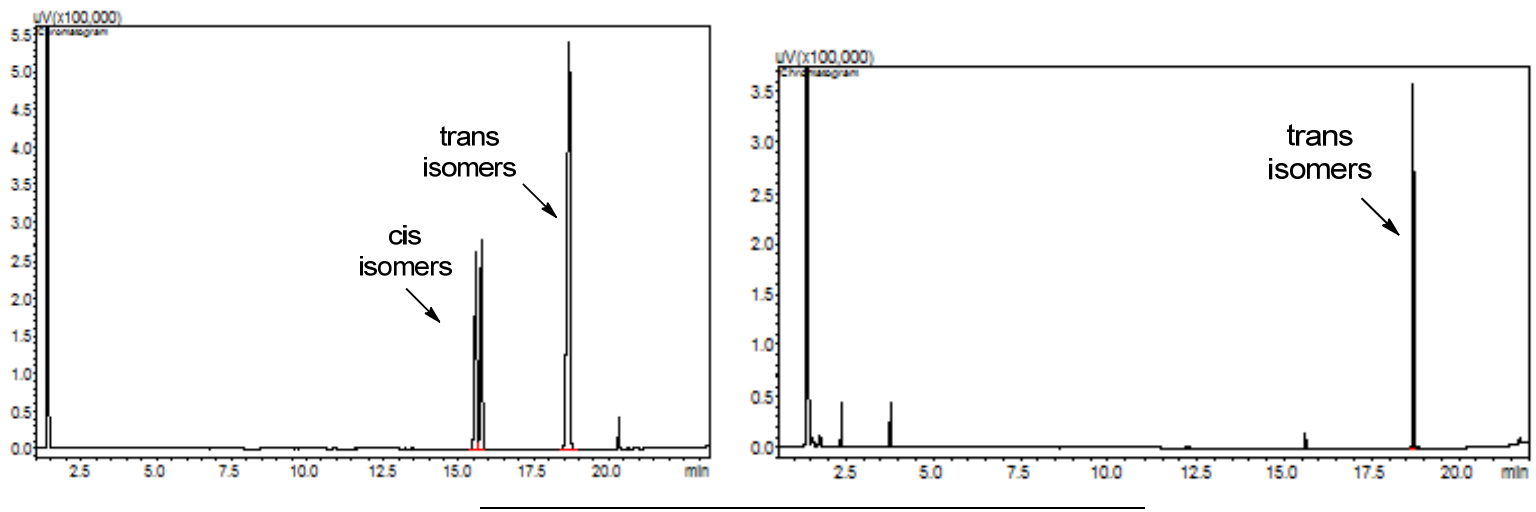

\begin{tabular}{ccc} 
Peak & Time & Area \\
\hline cis isomers & 15.5 & 5905 \\
trans isomers & 18.6 & 2104897 \\
\hline
\end{tabular}


Chiral GC analysis of trans and cis isomers $\mathbf{5 h}($ left $)$ and enzymatically produced $\mathbf{5 h}$ product (right):
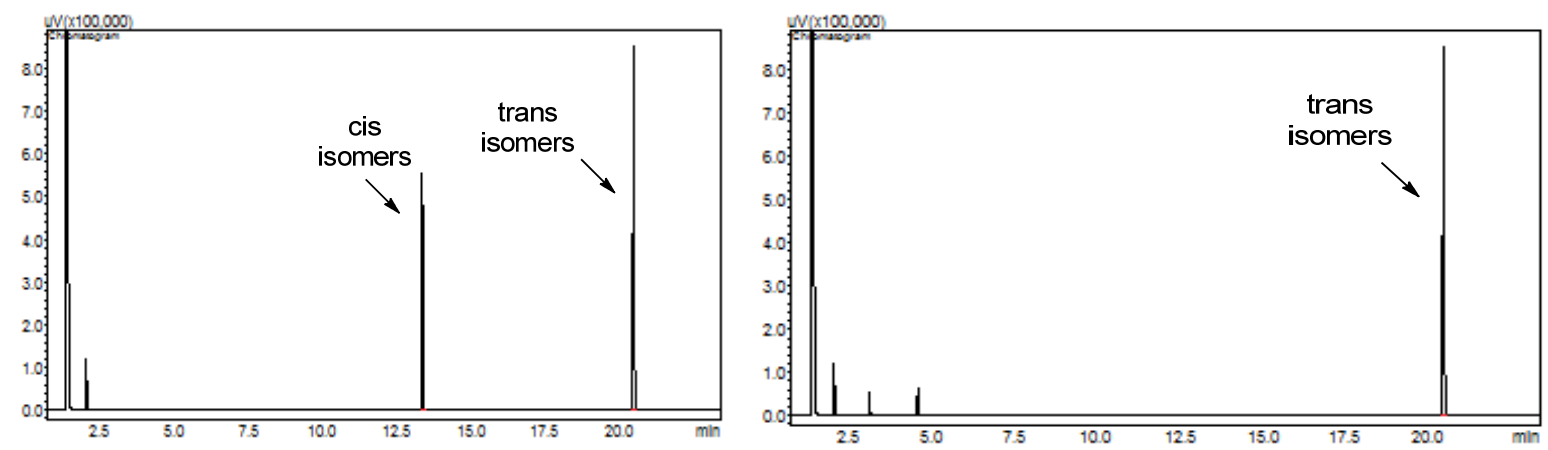

\begin{tabular}{ccc}
\hline Peak & Time & Area \\
\hline cis isomers & 13.5 & - \\
trans isomers & 20.4 & 2150557 \\
\hline
\end{tabular}

Chiral GC analysis of trans and cis isomers $\mathbf{5 i}($ left) and enzymatically produced $\mathbf{5 i}$ product (right):

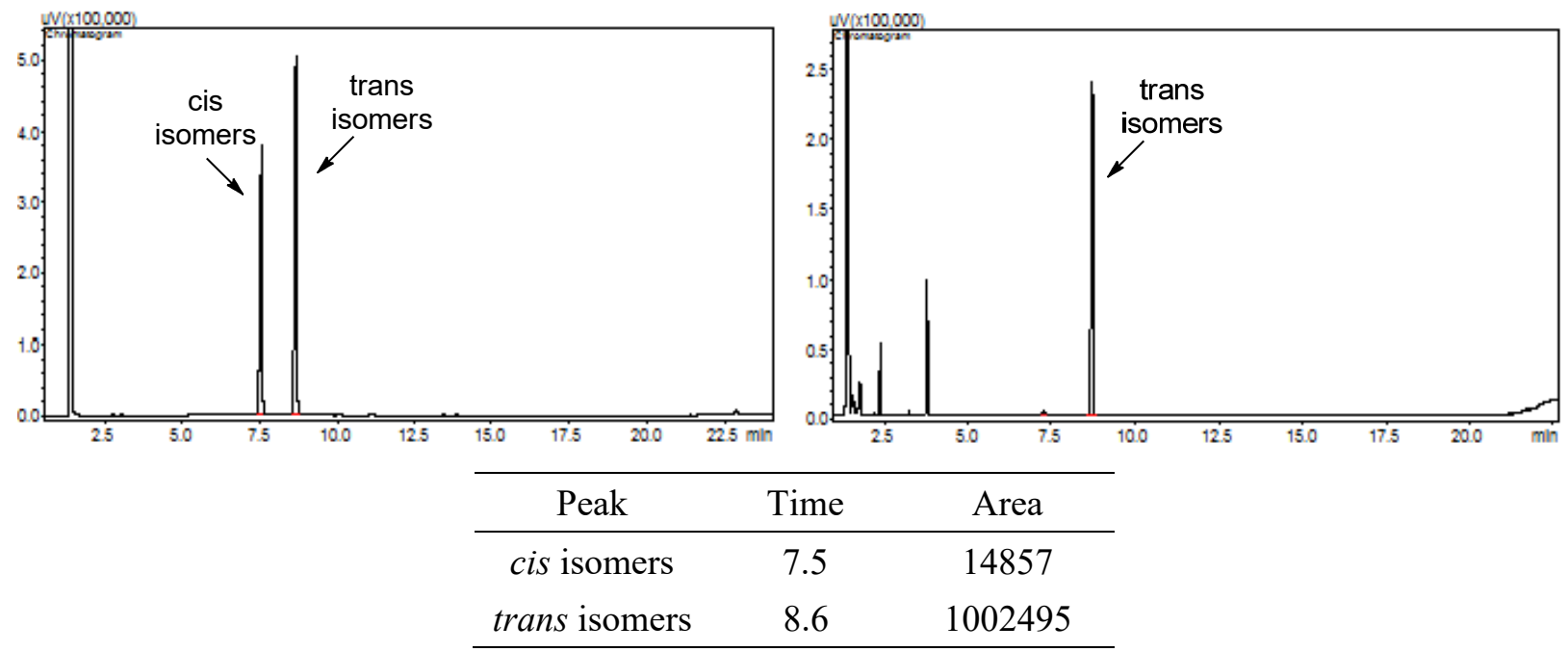


Chiral GC analysis of trans and cis isomers $\mathbf{5} \mathbf{j}(l e f t)$ and enzymatically produced $\mathbf{5} \mathbf{j}$ product (right):

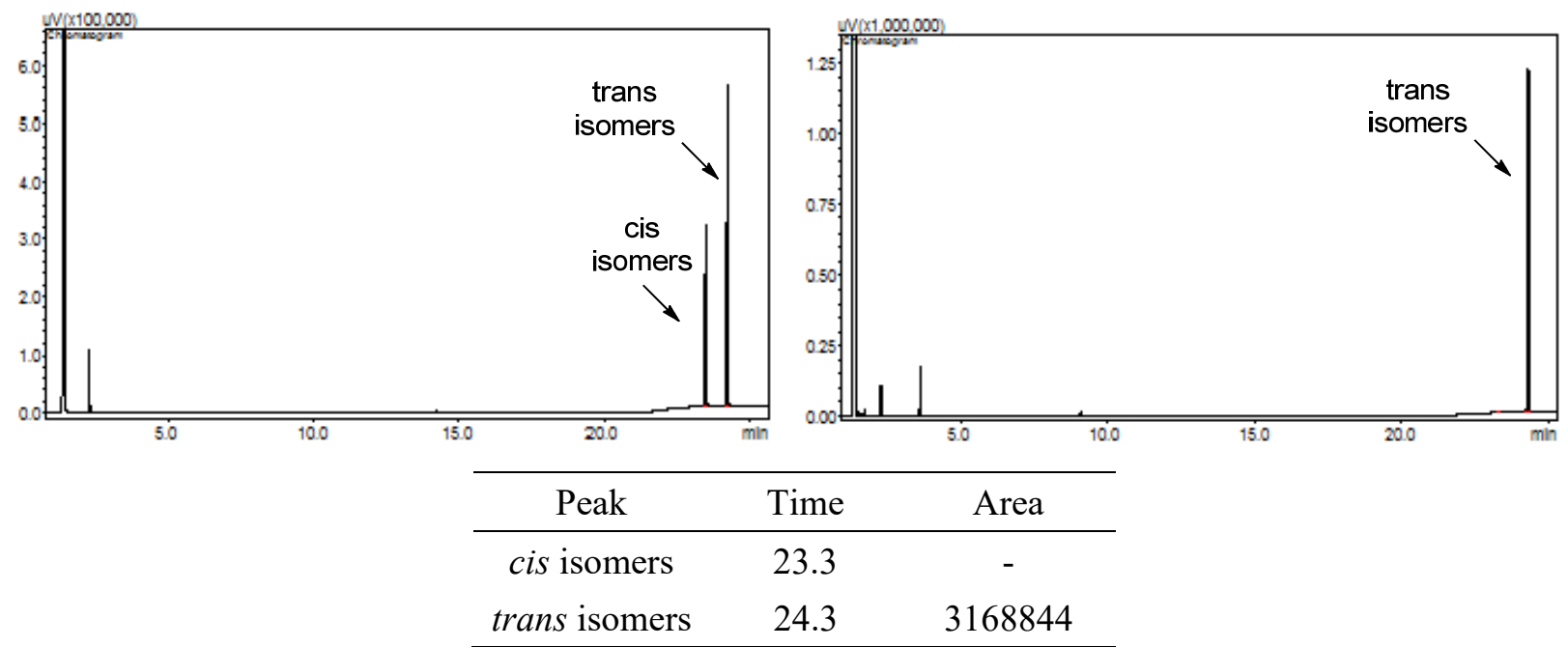

Chiral GC analysis of trans and cis isomers $\mathbf{5 k}$ (left) and enzymatically produced $\mathbf{5 k}$ product (right):
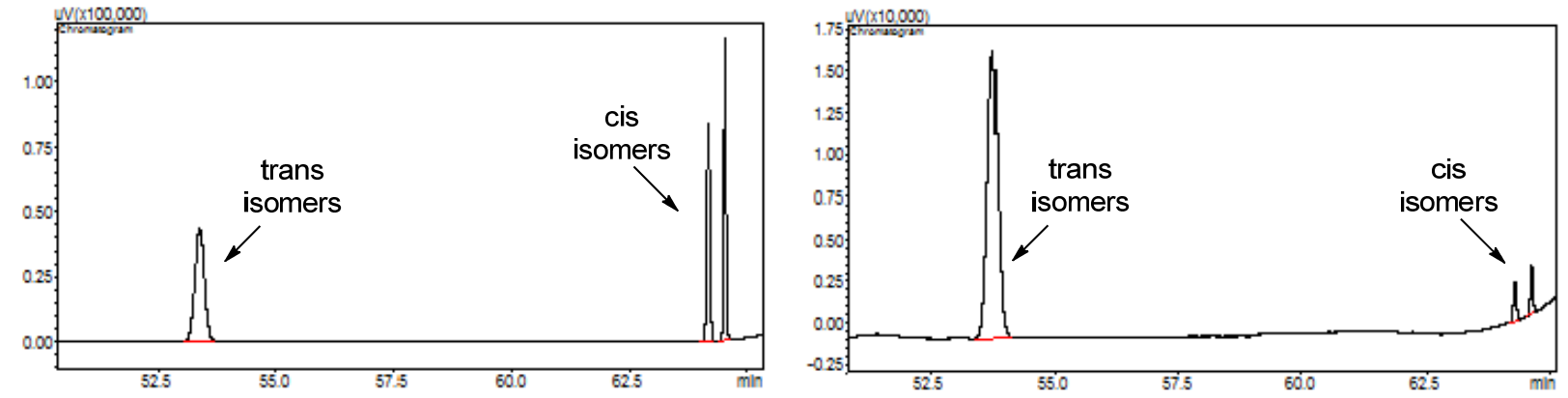

\begin{tabular}{ccc}
\hline Peak & Time & Area \\
\hline cis isomers & 64.5 & 17012 \\
trans isomers & 53.3 & 2866094 \\
\hline
\end{tabular}


Chiral GC analysis of trans and cis isomers $\mathbf{5 m}($ left $)$ and enzymatically produced $\mathbf{5 m}$ product (right):

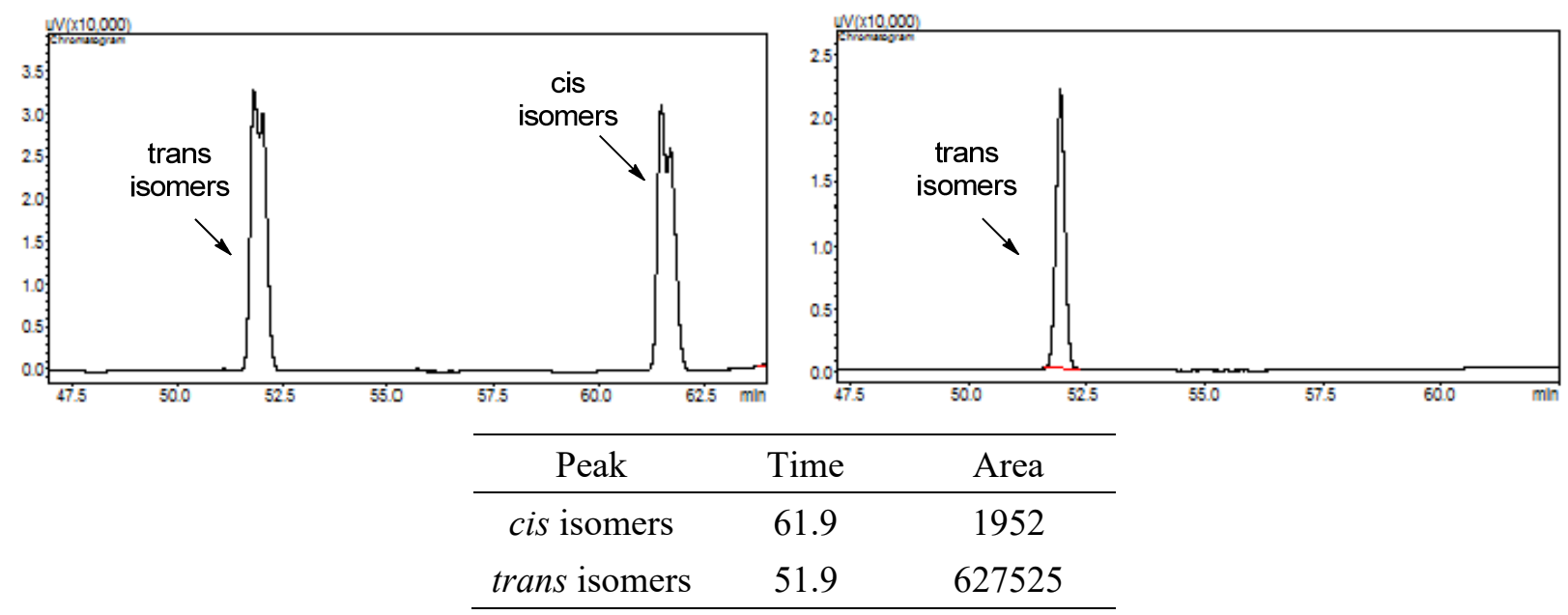

Chiral GC analysis of trans and cis isomers $\mathbf{5 n}$ (left) and enzymatically produced $\mathbf{5 n}$ product (right):

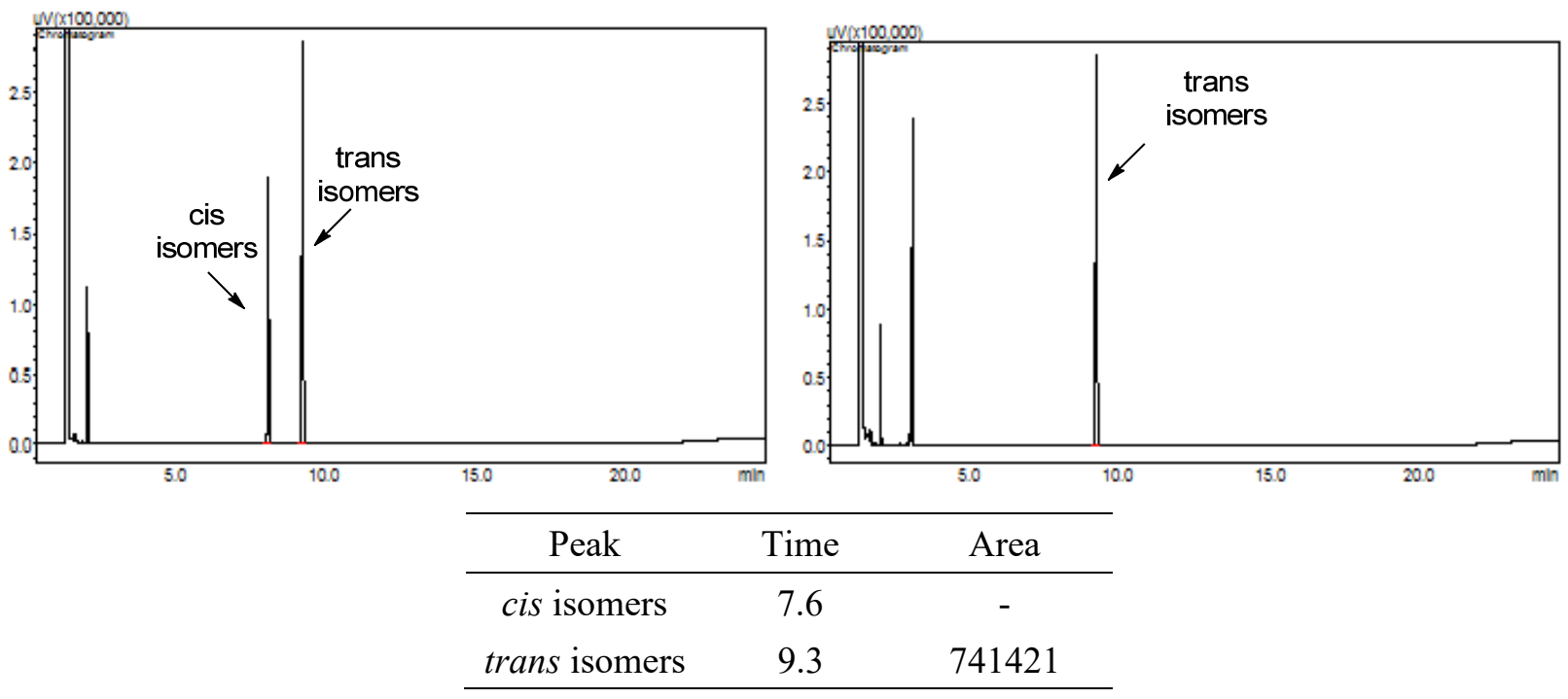


Chiral GC analysis of trans and cis isomers $\mathbf{5 0}$ (left) and enzymatically produced $\mathbf{5 0}$ product (right):

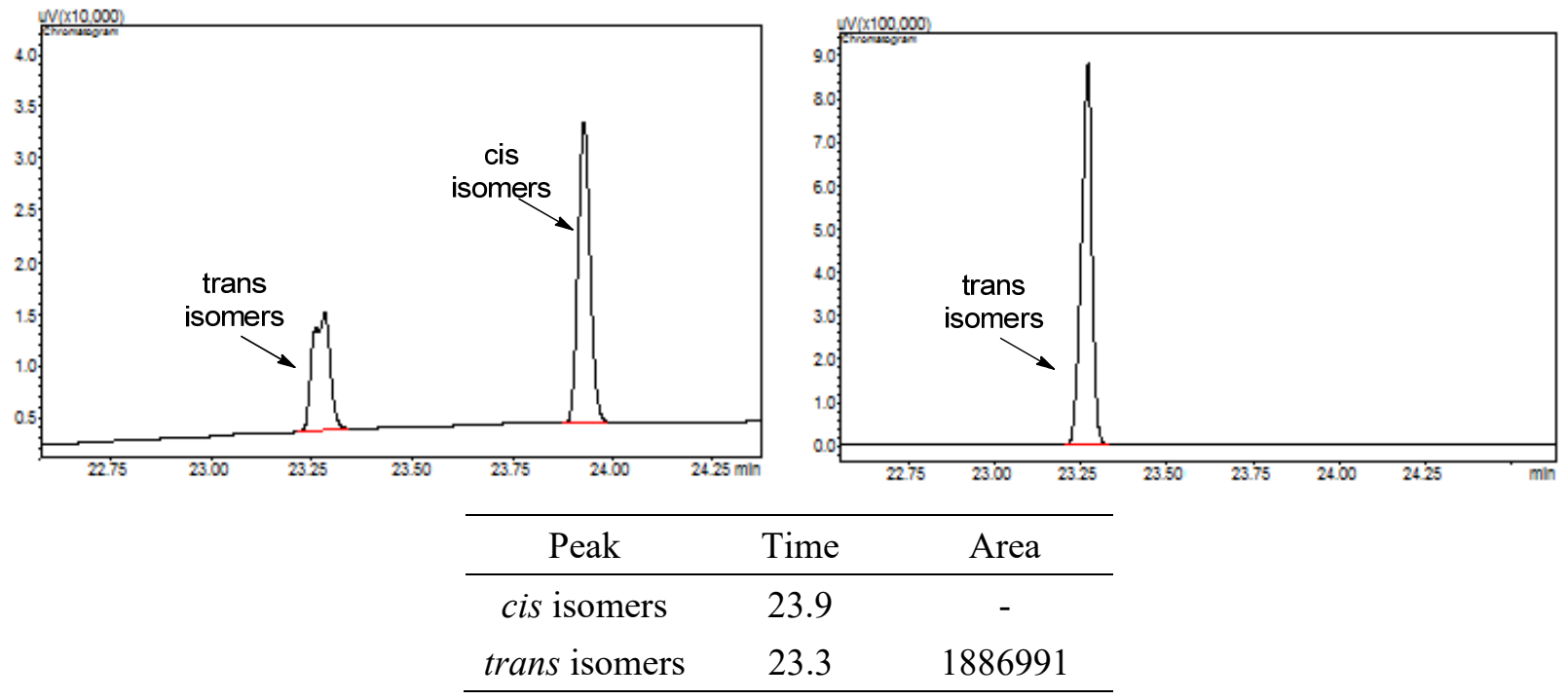

Chiral GC analysis of trans and cis isomers 5p (left) and enzymatically produced $\mathbf{5 p}$ product (right):

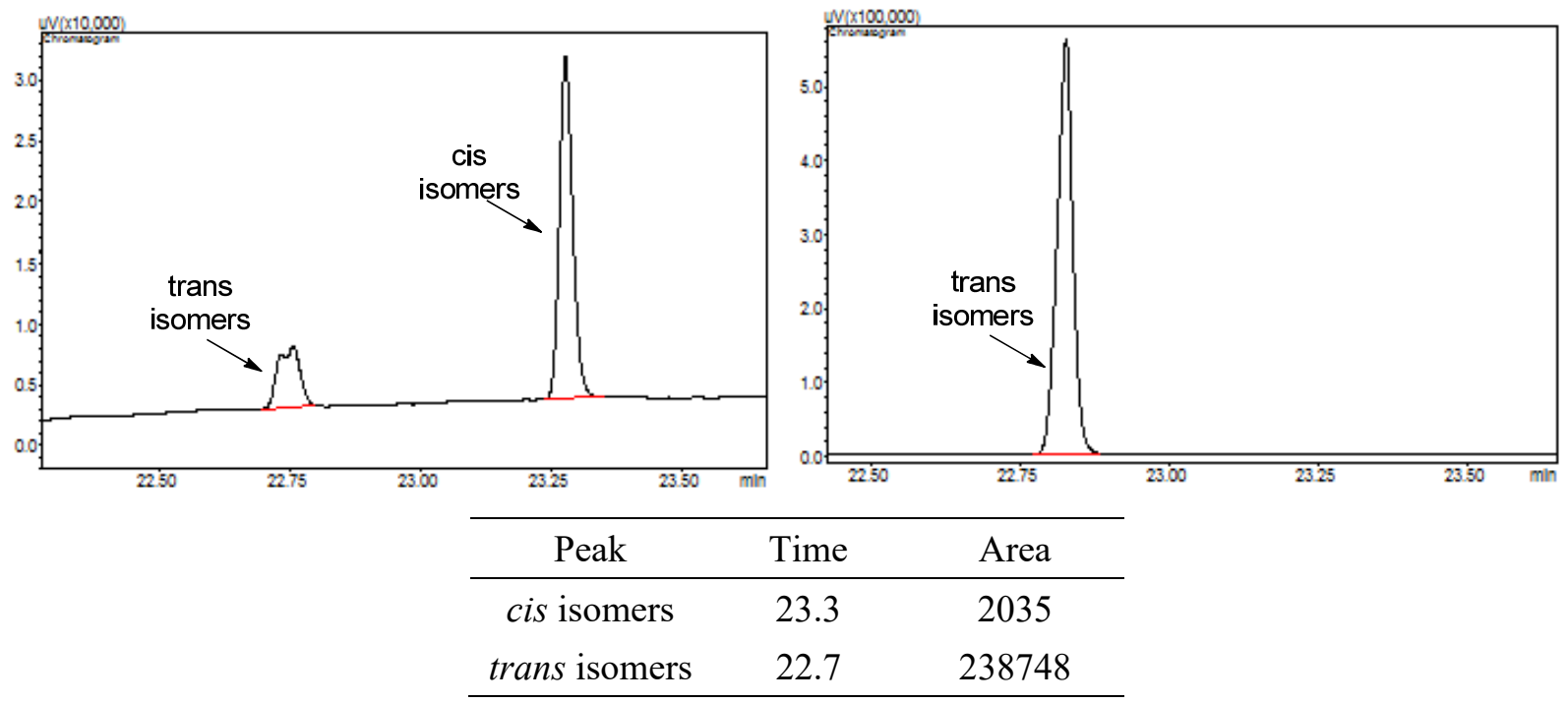


Chiral GC analysis of trans and cis isomers $\mathbf{5 q}($ left $)$ and enzymatically produced $\mathbf{5 q}$ product (right):
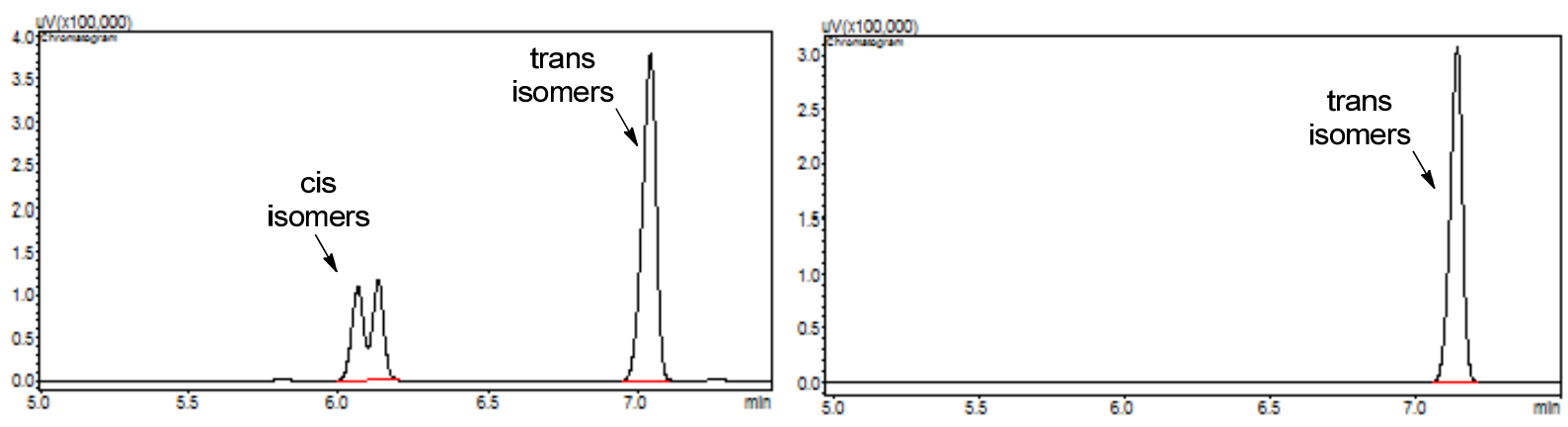

\begin{tabular}{ccc}
\hline Peak & Time & Area \\
\hline cis isomers & 6.1 & 1936 \\
trans isomers & 7.1 & 426111
\end{tabular}

Chiral GC analysis of trans and cis isomers $\mathbf{5 s}$ (left) and enzymatically produced $\mathbf{5 s}$ product (right):
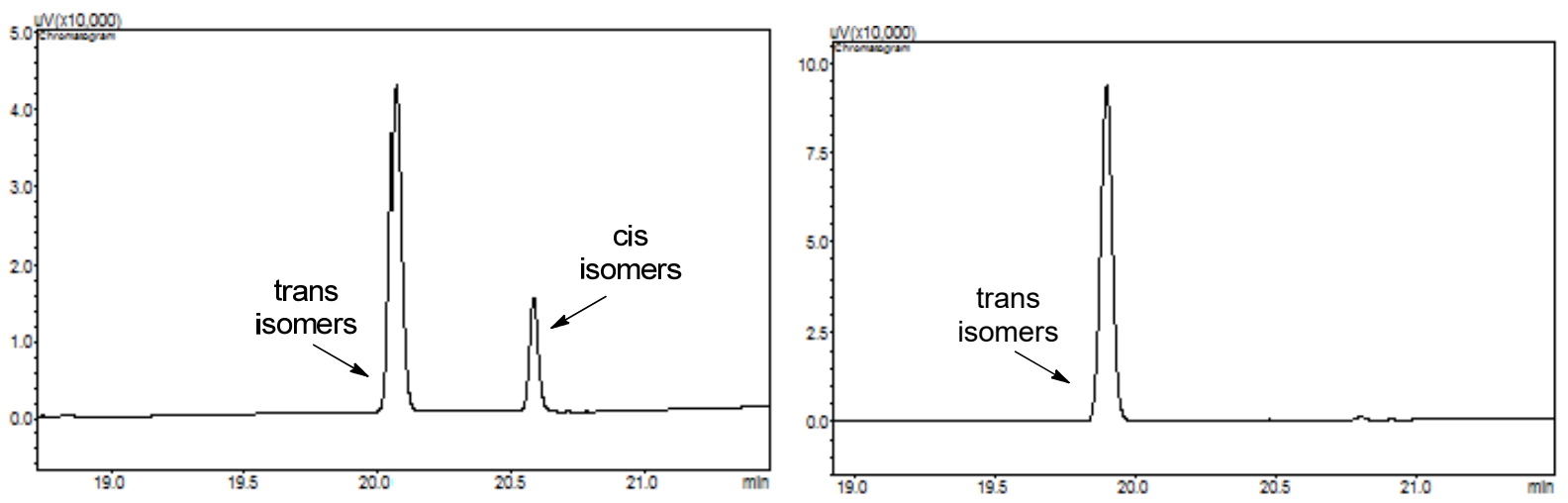

\begin{tabular}{ccc}
\hline Peak & Time & Area \\
\hline cis isomers & 20.1 & 7673 \\
trans isomers & 20.7 & 1653290 \\
\hline
\end{tabular}


Chiral GC analysis of trans and cis isomers $\mathbf{5 t}($ left) and enzymatically produced $\mathbf{5 t}$ product (right):

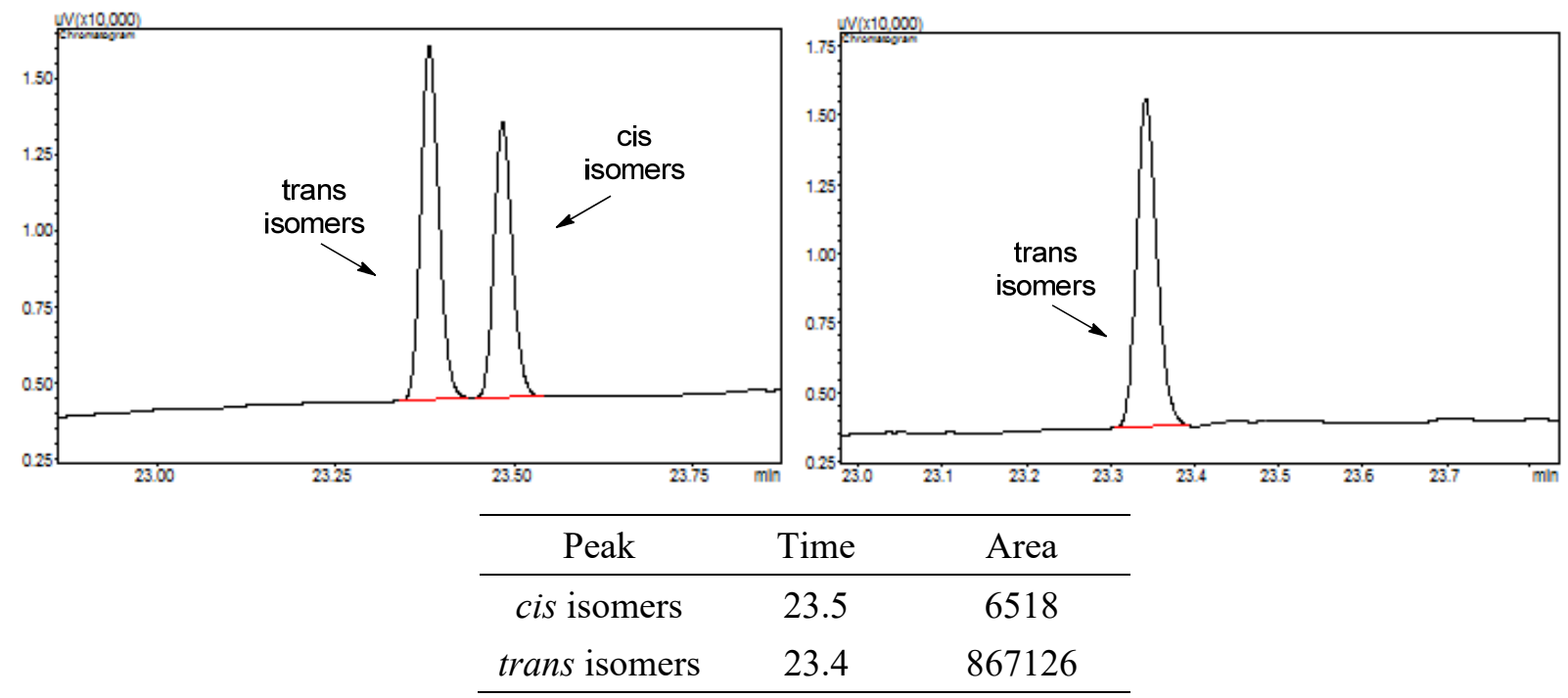

Chiral GC analysis of trans and cis isomers $5 \mathbf{u}(l e f t)$ and enzymatically produced $\mathbf{5 u}$ product (right):

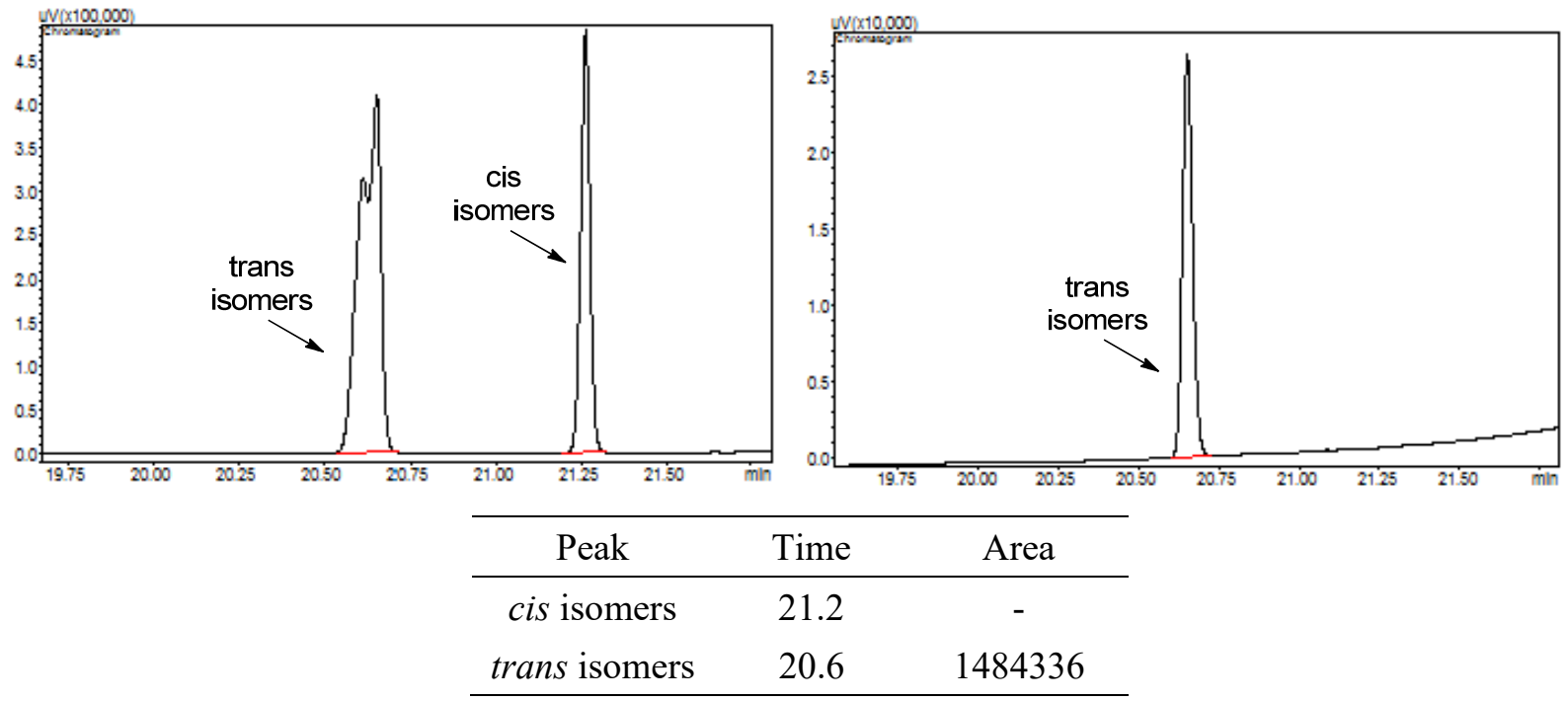


Chiral GC analysis of trans and cis isomers $\mathbf{5 v}$ (left) and enzymatically produced $\mathbf{5 v}$ product (right):
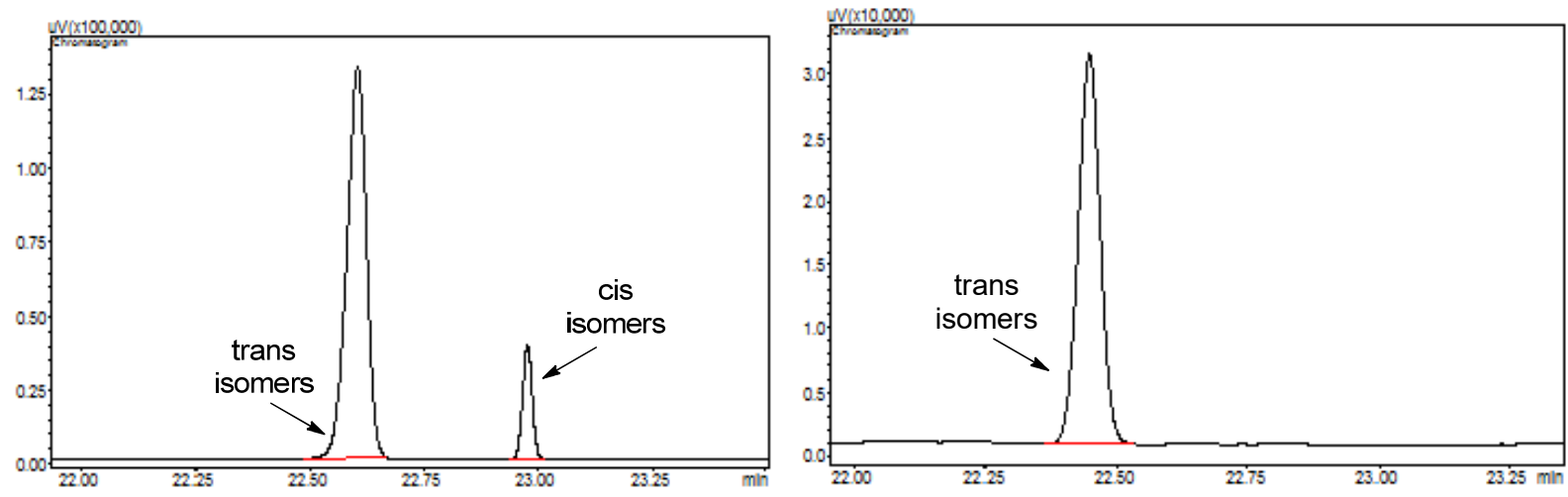

\begin{tabular}{ccc}
\hline Peak & Time & Area \\
\hline cis isomers & 22.9 & - \\
trans isomers & 22.6 & 145224 \\
\hline
\end{tabular}

Chiral GC analysis of trans and cis isomers $\mathbf{5 w}$ (left) and enzymatically produced $\mathbf{5 w}$ product (right):

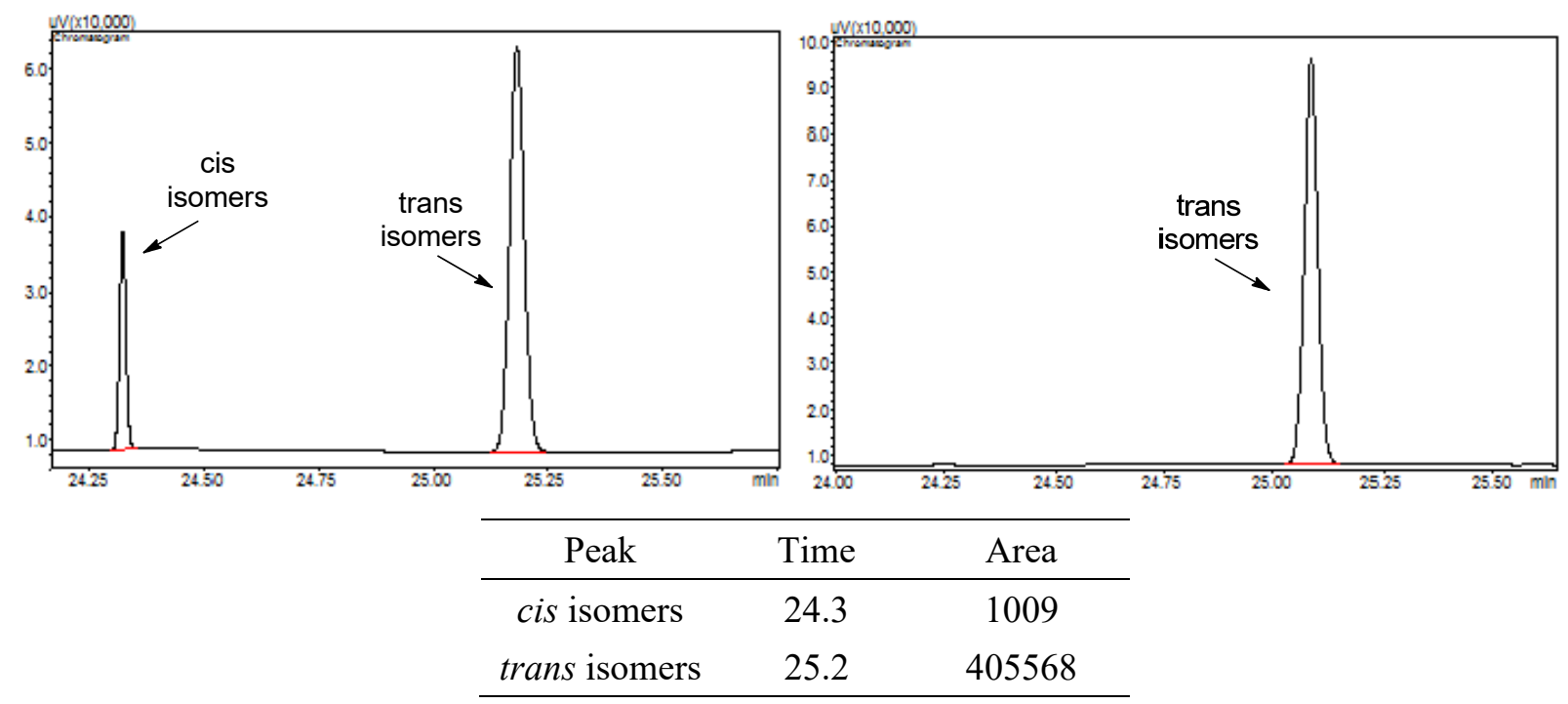


Figure S9. Chiral GC and SFC analyses for determination of enantiomeric excesses in the cyclopropanation reactions catalyzed by $\mathrm{Mb}(\mathrm{H} 64 \mathrm{~V}, \mathrm{~V} 68 \mathrm{~A}, \mathrm{H} 93 \mathrm{NMH})[\mathrm{Fe}(\mathrm{DADP})]$ (3). The reference racemic samples were prepared as described in the experimental procedures.

Chiral GC analysis of racemic trans 5a (left) and enzymatically produced 5a product (right):

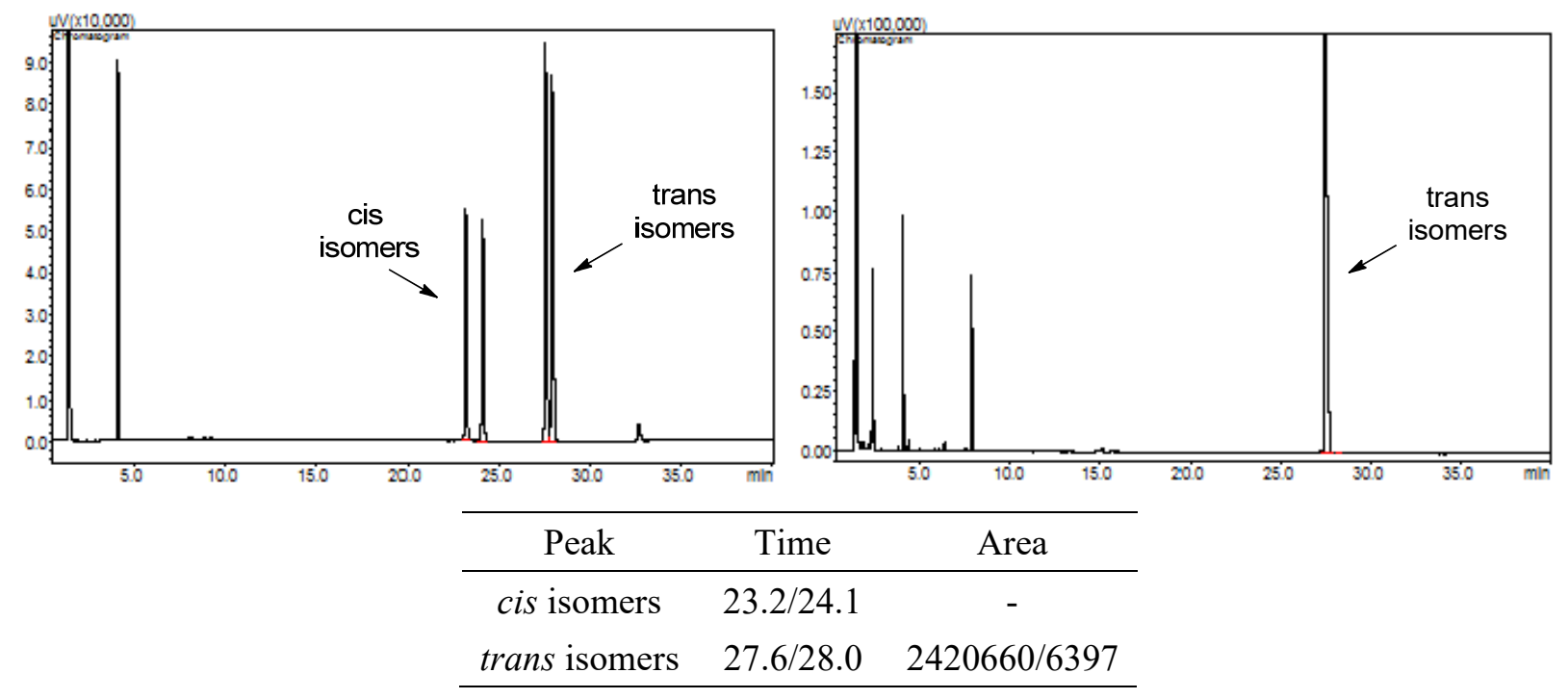

Chiral SFC analysis of racemic trans $\mathbf{5 b}$ (left) and enzymatically produced $\mathbf{5 b}$ product (right):
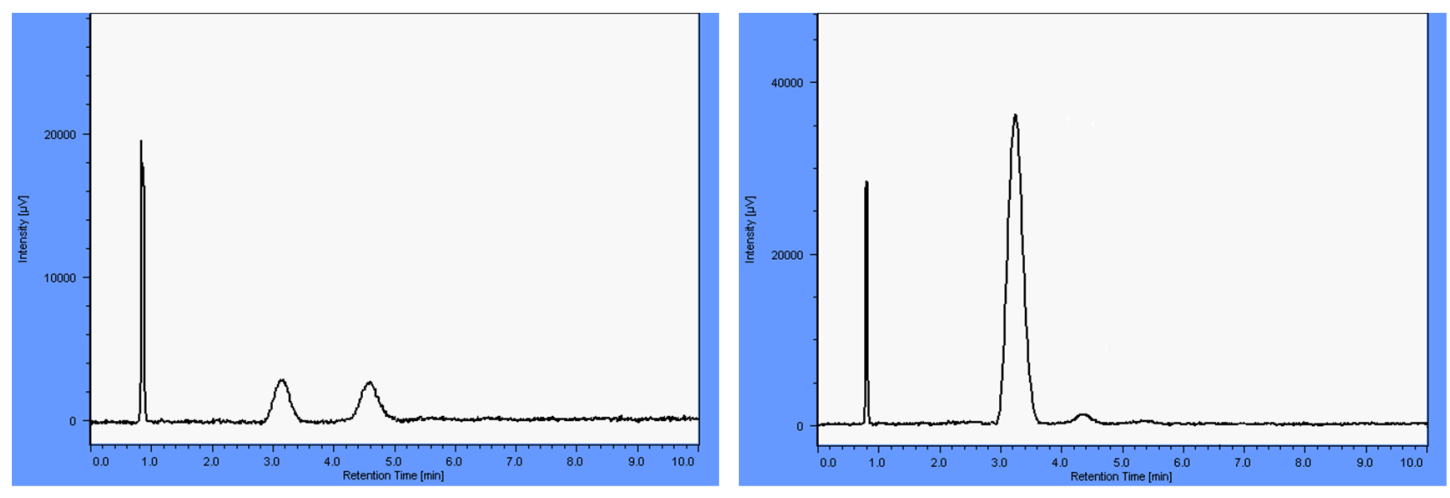

\begin{tabular}{ccc}
\hline Peak & Time & Area \\
\hline 1 & 3.25 & 631140 \\
2 & 4.40 & 2813 \\
\hline
\end{tabular}


Chiral SFC analysis of racemic trans $\mathbf{5 c}$ (left) and enzymatically produced $\mathbf{5 c}$ product (right):
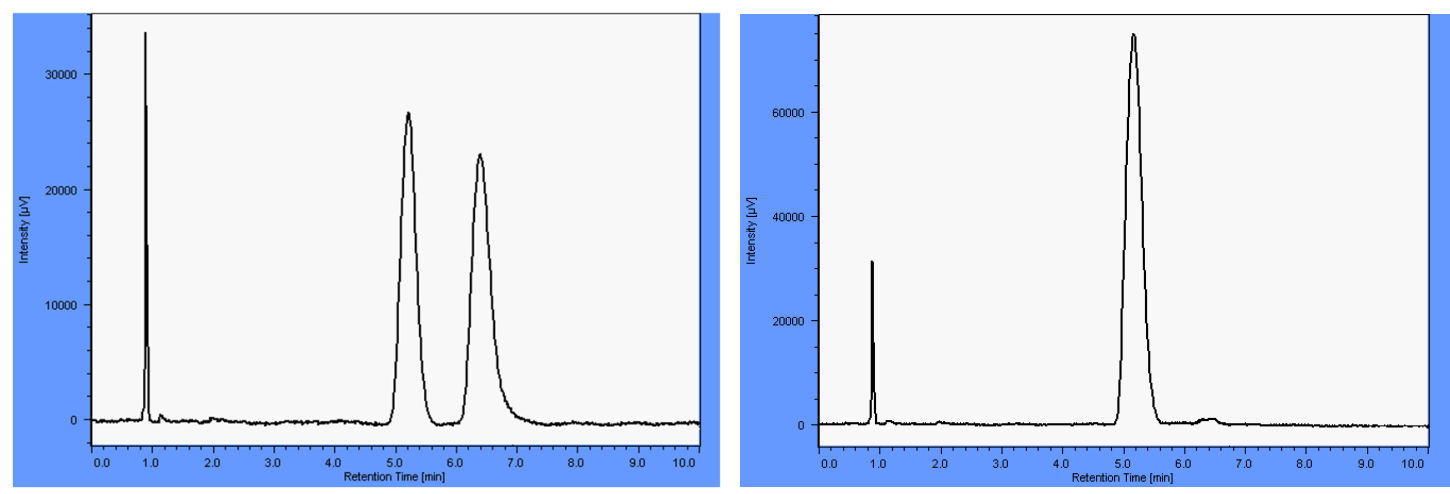

\begin{tabular}{ccc}
\hline Peak & Time & Area \\
\hline 1 & 5.20 & 1377727 \\
2 & 6.50 & 5236 \\
\hline
\end{tabular}

$>\quad$ Chiral SFC analysis of racemic trans $\mathbf{5 d}$ (left) and enzymatically produced $\mathbf{5 d}$ product (right):
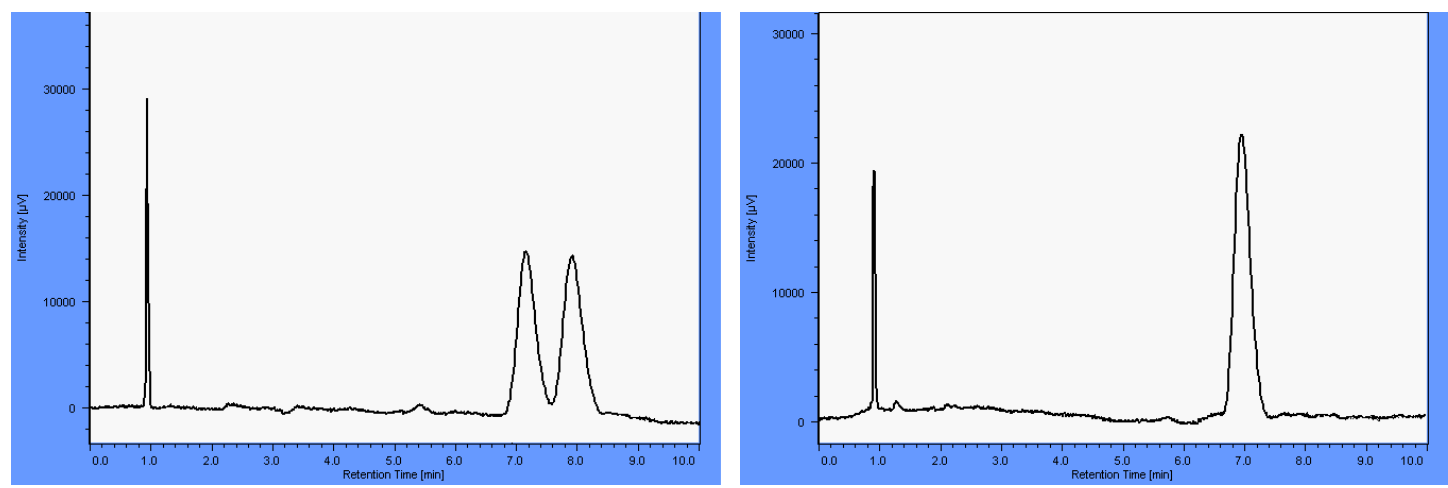

\begin{tabular}{ccc}
\hline Peak & Time & Area \\
\hline 1 & 7.25 & 402402 \\
2 & 8.05 & 3678 \\
\hline
\end{tabular}


Chiral SFC analysis of racemic trans $\mathbf{5 e}($ left) and enzymatically produced 5e product (right):
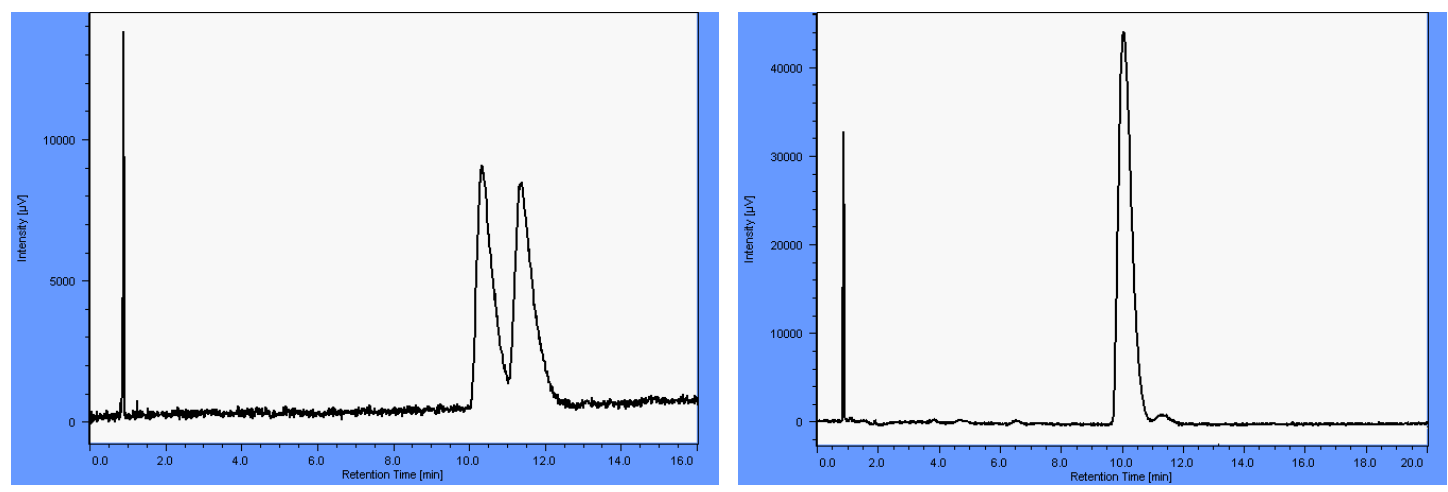

\begin{tabular}{ccc}
\hline Peak & Time & Area \\
\hline 1 & 3.25 & 411140 \\
2 & 4.40 & 2813 \\
\hline
\end{tabular}

Chiral SFC analysis of racemic trans-5f (left) and enzymatically produced $\mathbf{5 f}$ product (right):
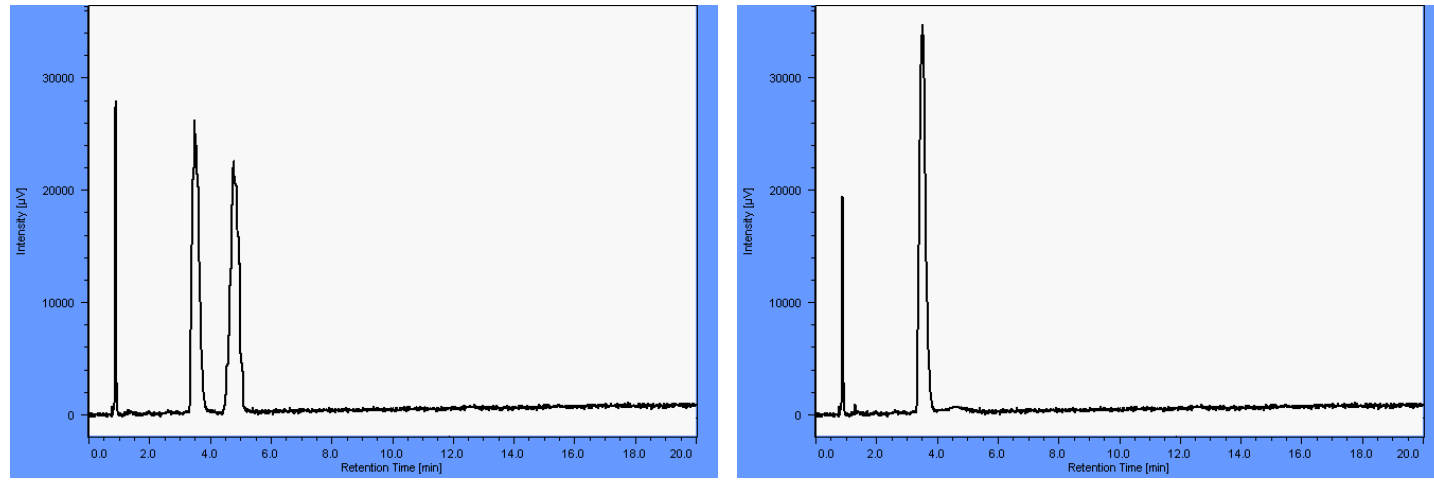

\begin{tabular}{ccc}
\hline Peak & Time & Area \\
\hline 1 & 3.50 & 1346175 \\
2 & 4.35 & 4948 \\
\hline
\end{tabular}


Chiral SFC analysis of racemic trans $\mathbf{5 g}$ (left) and enzymatically produced $\mathbf{5 g}$ product (right):
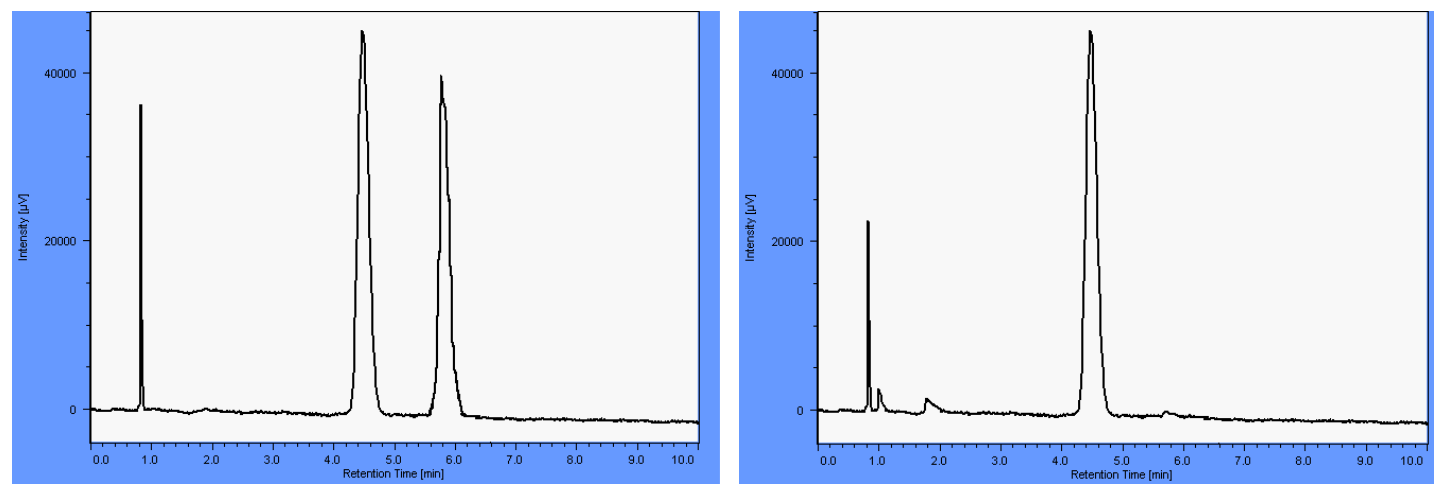

\begin{tabular}{ccc}
\hline Peak & Time & Area \\
\hline 1 & 4.45 & 380249 \\
2 & 5.80 & 2043 \\
\hline
\end{tabular}

Chiral SFC analysis of racemic trans $\mathbf{5 h}$ (left) and enzymatically produced $\mathbf{5 h}$ product (right):
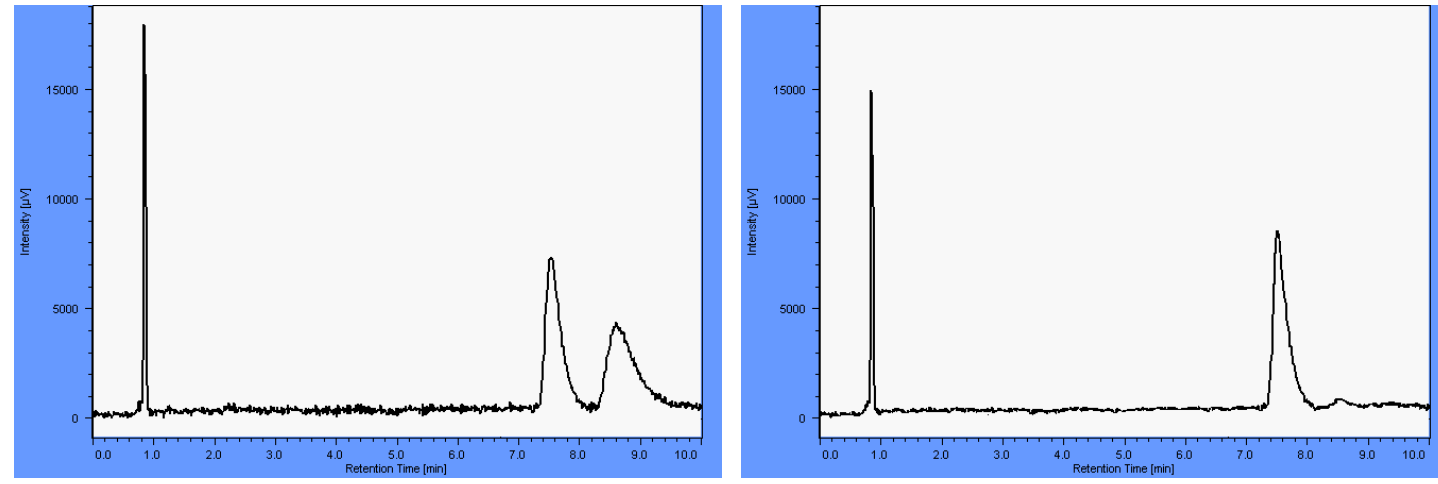

\begin{tabular}{ccc}
\hline Peak & Time & Area \\
\hline 1 & 7.65 & 63282 \\
2 & 8.80 & 576 \\
\hline
\end{tabular}


Chiral SFC analysis of racemic trans $\mathbf{5 i}$ (left) and enzymatically produced $\mathbf{5 i}$ product (right):
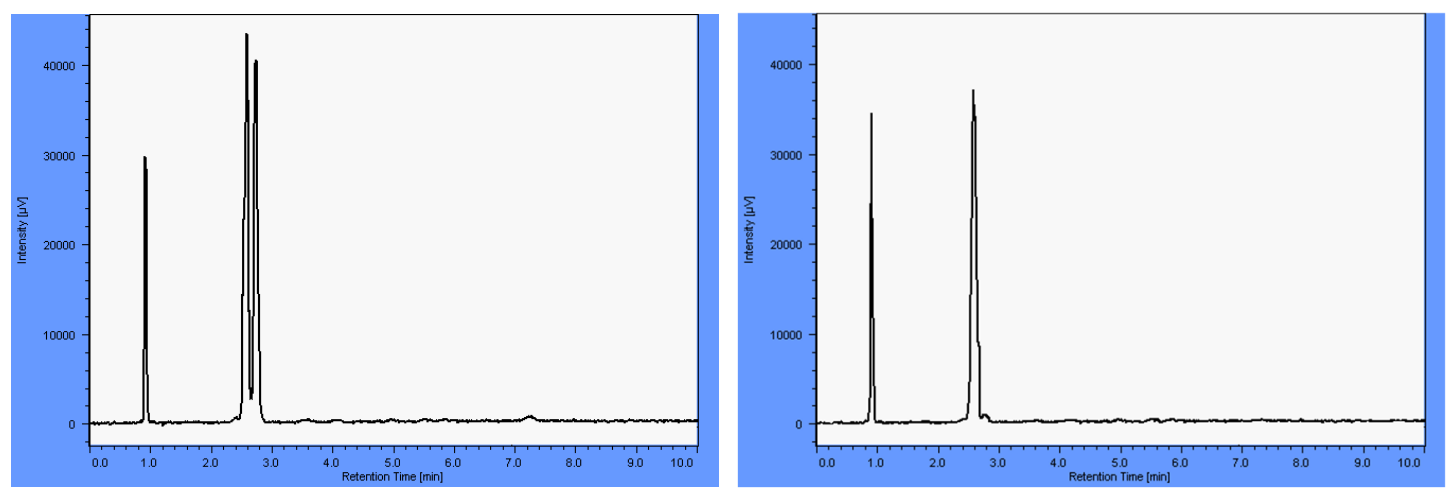

\begin{tabular}{ccc}
\hline Peak & Time & Area \\
\hline 1 & 2.55 & 1413586 \\
2 & 2.80 & 8200 \\
\hline
\end{tabular}

Chiral SFC analysis of racemic trans $\mathbf{5 j}$ (left) and enzymatically produced $\mathbf{5 j}$ product (right):
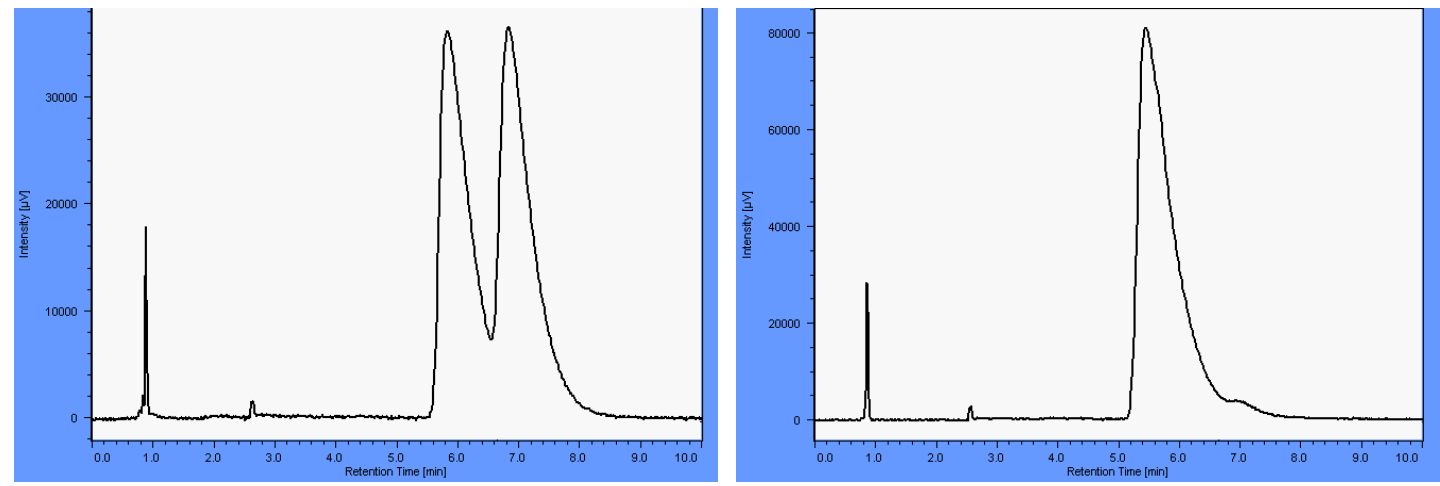

\begin{tabular}{ccc}
\hline Peak & Time & Area \\
\hline 1 & 5.90 & 1978276 \\
2 & 7.20 & 9255 \\
\hline
\end{tabular}


Chiral SFC analysis of racemic trans $\mathbf{5 k}$ (left) and enzymatically produced $\mathbf{5 k}$ product (right):
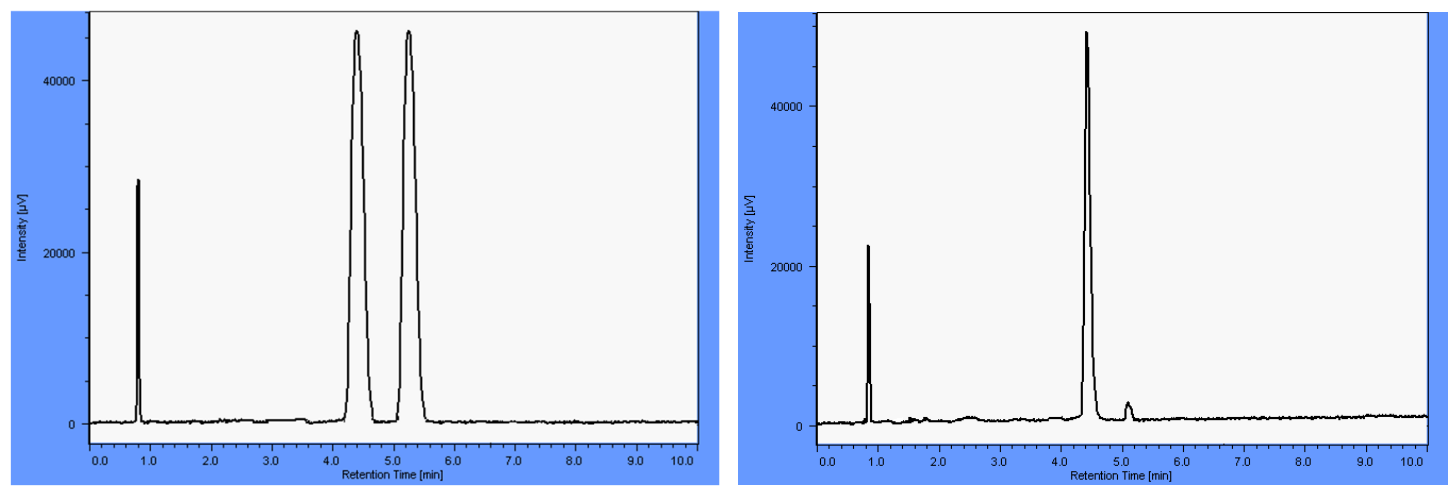

\begin{tabular}{ccc}
\hline Peak & Time & Area \\
\hline 1 & 4.60 & 150620 \\
2 & 5.35 & 9841 \\
\hline
\end{tabular}

Chiral GC analysis of trans and cis isomers $\mathbf{5 l}$ (left) and enzymatically produced $\mathbf{5 l}$ product (right):

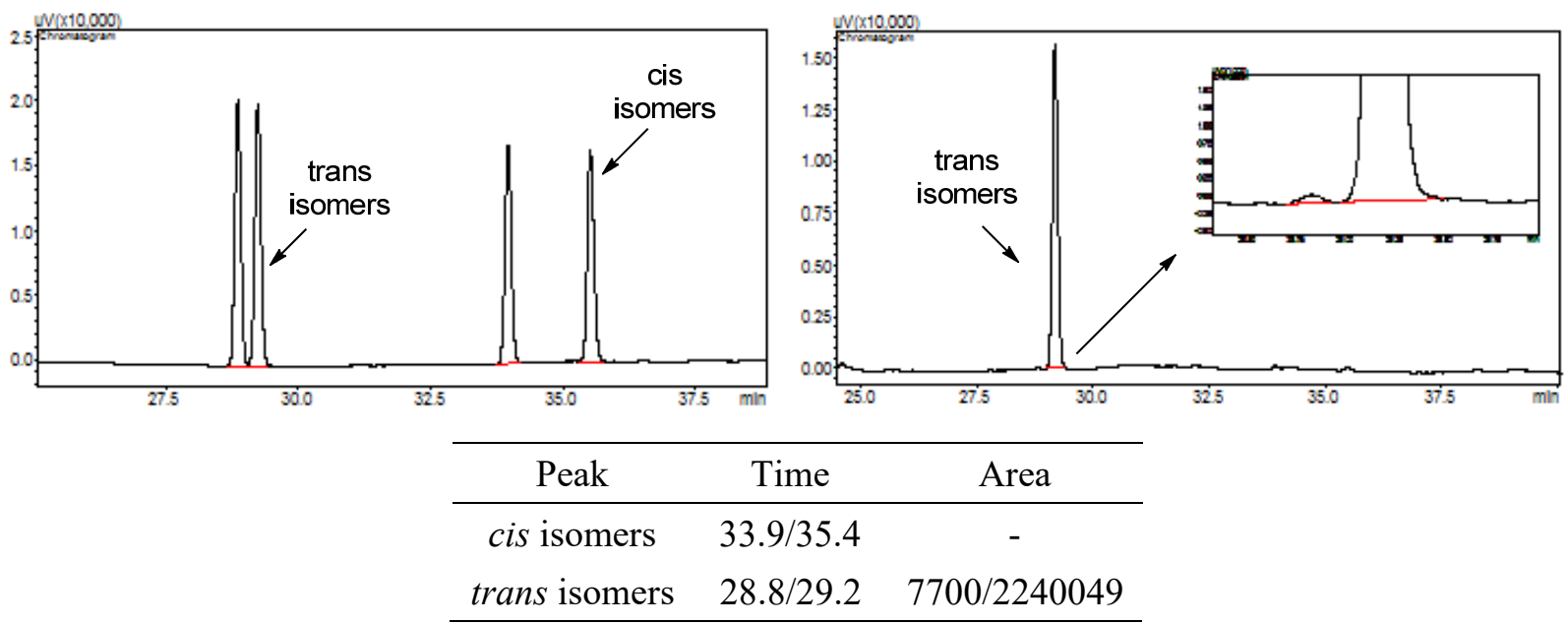


Chiral SFC analysis of racemic trans $\mathbf{5 m}$ (left) and enzymatically produced $\mathbf{5 m}$ product (right):
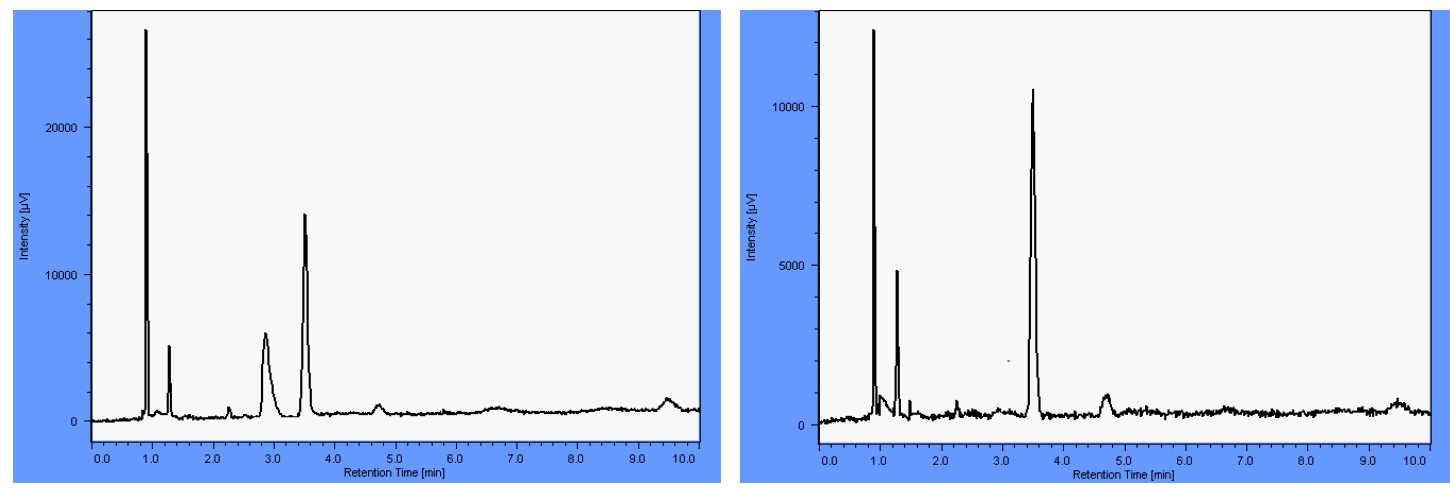

\begin{tabular}{ccc}
\hline Peak & Time & Area \\
\hline 1 & 3.1 & 52948 \\
2 & 3.5 & - \\
\hline
\end{tabular}

Chiral SFC analysis of racemic trans $\mathbf{5 n}$ (left) and enzymatically produced $\mathbf{5 n}$ product (right):
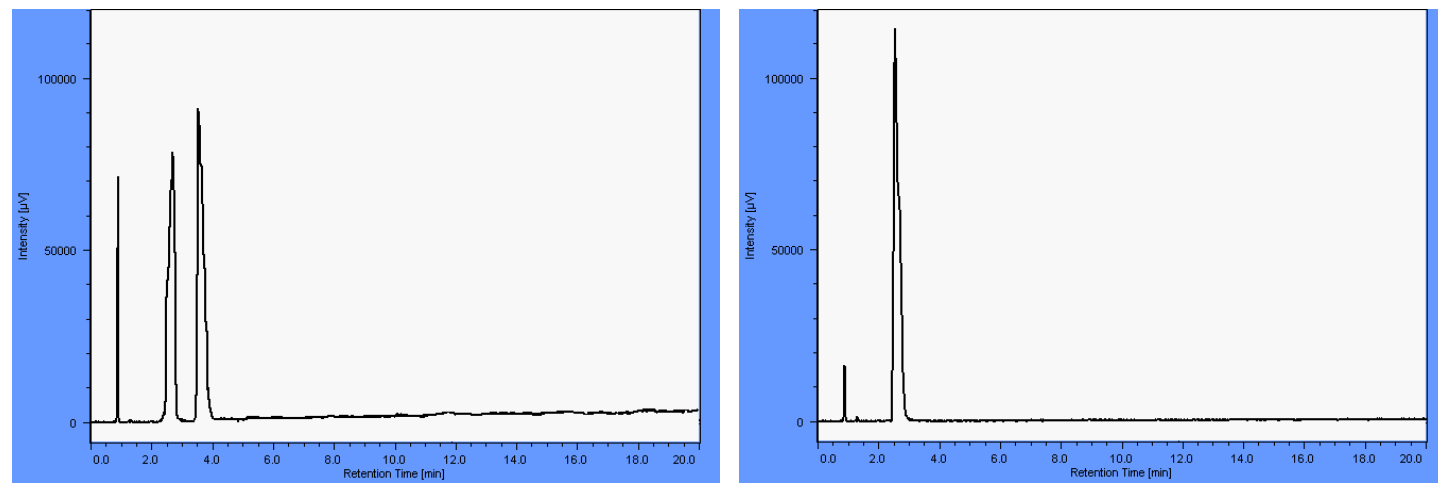

\begin{tabular}{ccc}
\hline Peak & Time & Area \\
\hline 1 & 2.65 & 508466 \\
2 & 3.75 & - \\
\hline
\end{tabular}


Chiral SFC analysis of racemic trans $\mathbf{5 0}$ (left) and enzymatically produced $\mathbf{5 0}$ product (right):
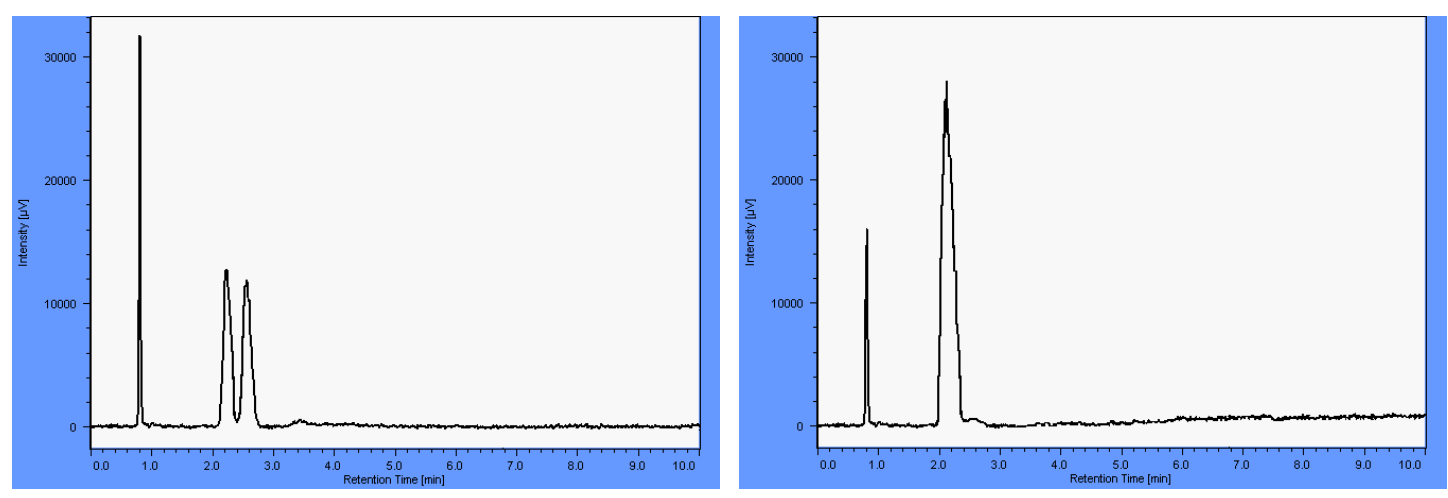

\begin{tabular}{ccc}
\hline Peak & Time & Area \\
\hline 1 & 2.19 & 474764 \\
2 & 2.60 & 834 \\
\hline
\end{tabular}

Chiral SFC analysis of racemic trans $\mathbf{5 p}$ (left) and enzymatically produced $\mathbf{5 p}$ product (right):
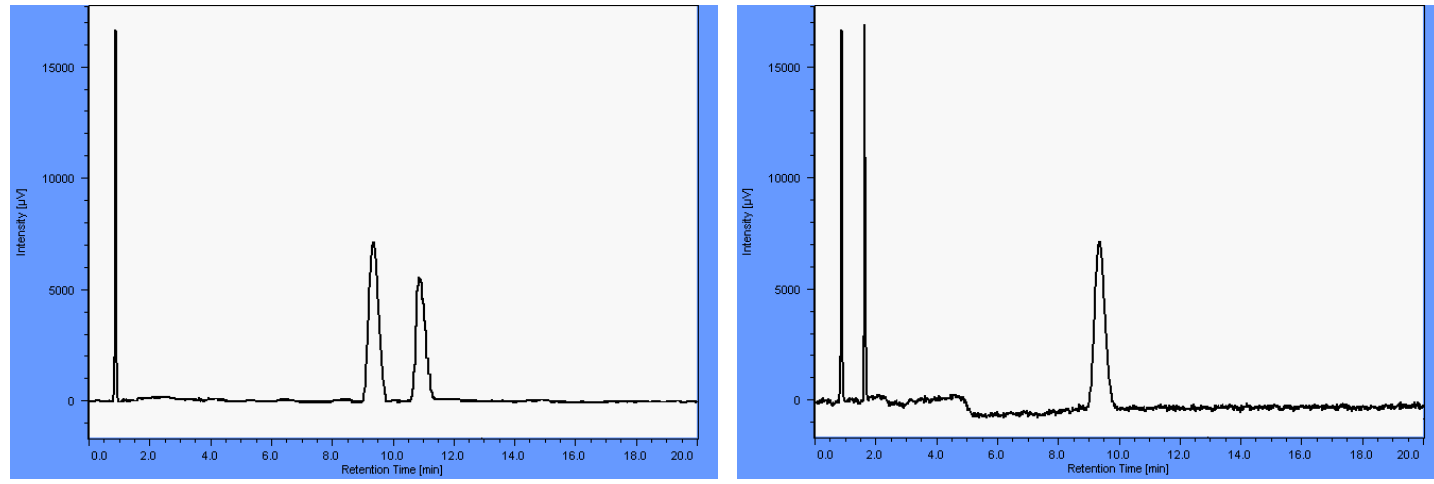

\begin{tabular}{ccc}
\hline Peak & Time & Area \\
\hline 1 & 9.40 & 148758 \\
2 & 11.0 & - \\
\hline
\end{tabular}


Chiral SFC analysis of racemic trans $\mathbf{5 q}$ (left) and enzymatically produced $\mathbf{5 q}$ product (right):
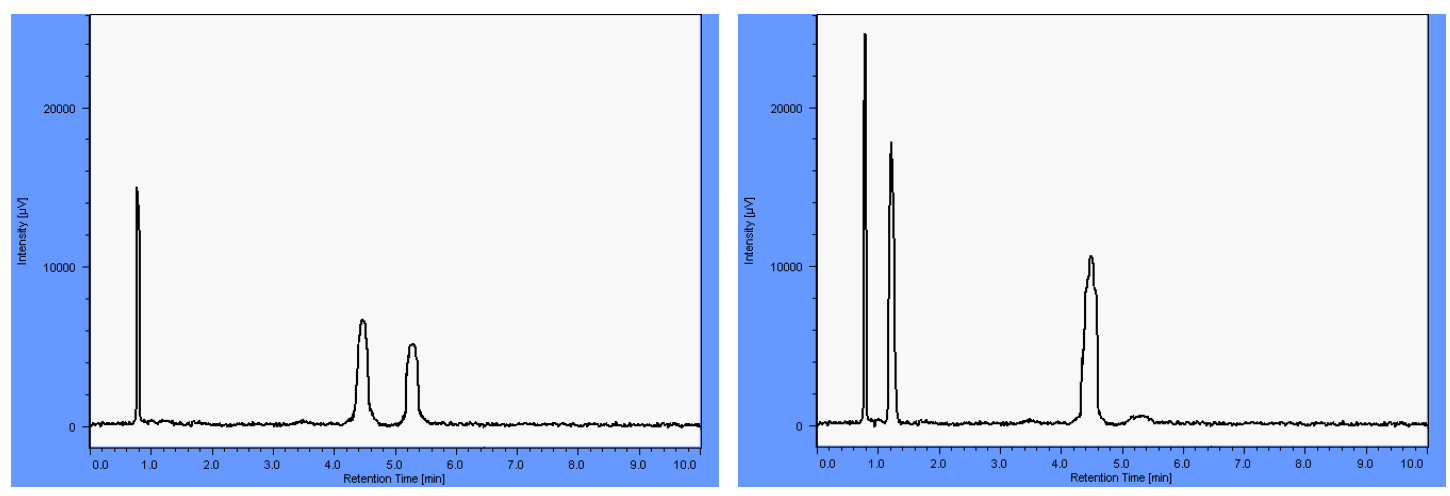

\begin{tabular}{ccc}
\hline Peak & Time & Area \\
\hline 1 & 4.40 & 65907 \\
2 & 5.30 & 4739 \\
\hline
\end{tabular}

Chiral GC analysis of enzymatically produced trans $\mathbf{5 r}$ product:

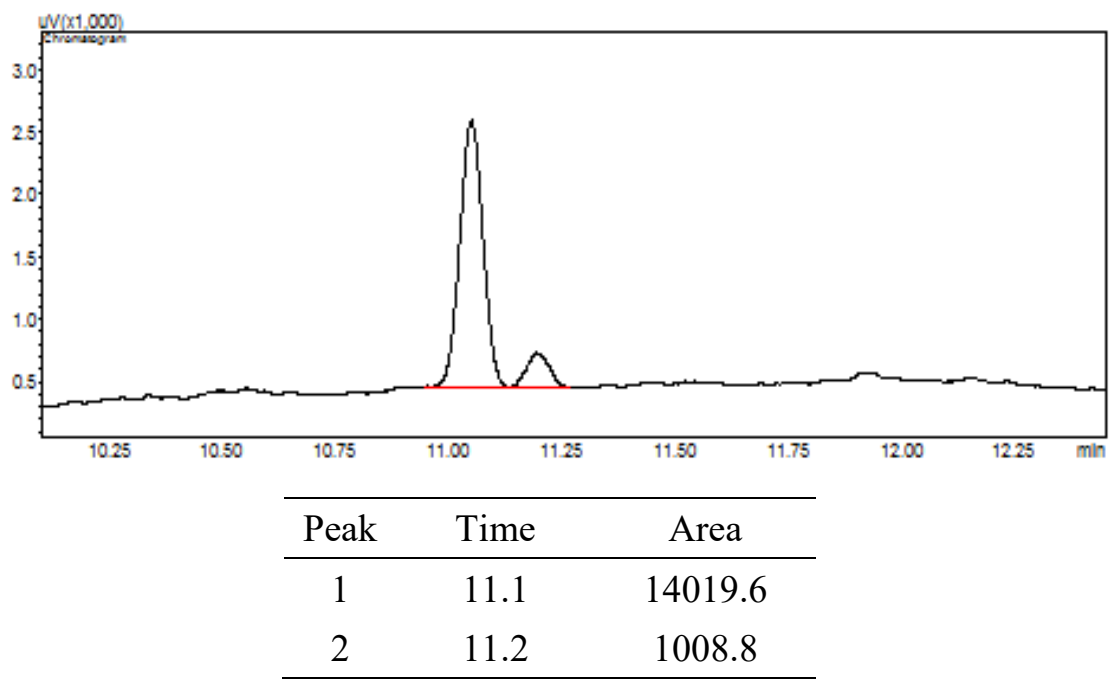


Chiral SFC analysis of racemic trans $\mathbf{5 s}$ (left) and enzymatically produced $\mathbf{5 s}$ product (right):
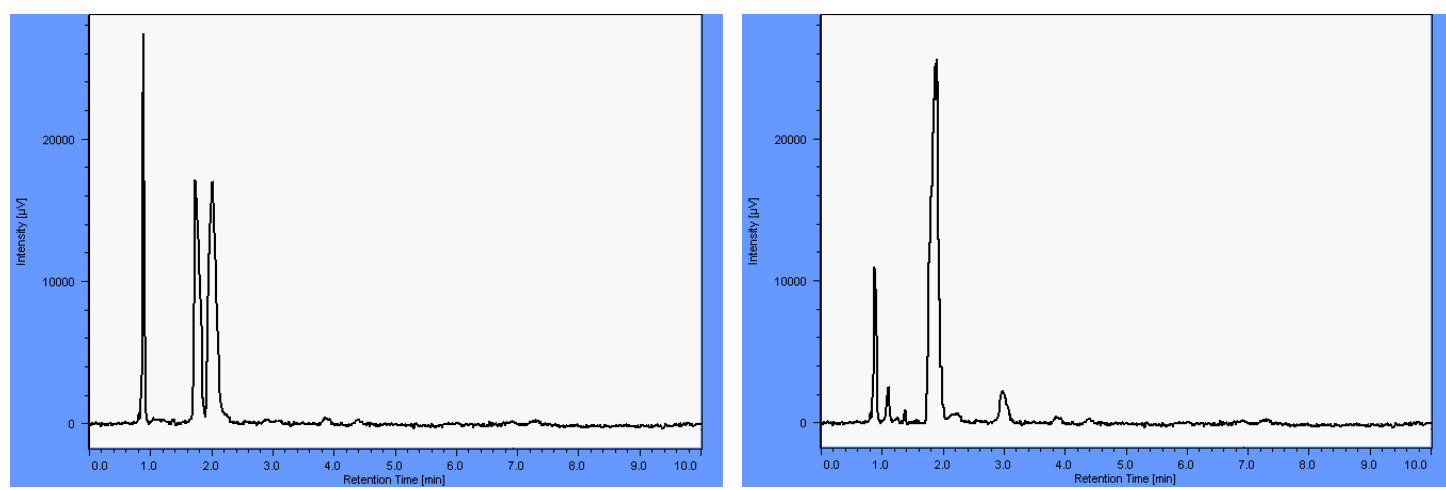

\begin{tabular}{ccc}
\hline Peak & Time & Area \\
\hline 1 & 1.70 & 158927 \\
2 & 2.10 & 866 \\
\hline
\end{tabular}

Chiral SFC analysis of racemic trans $\mathbf{5 t}($ left $)$ and enzymatically produced $\mathbf{5 t}$ product (right):
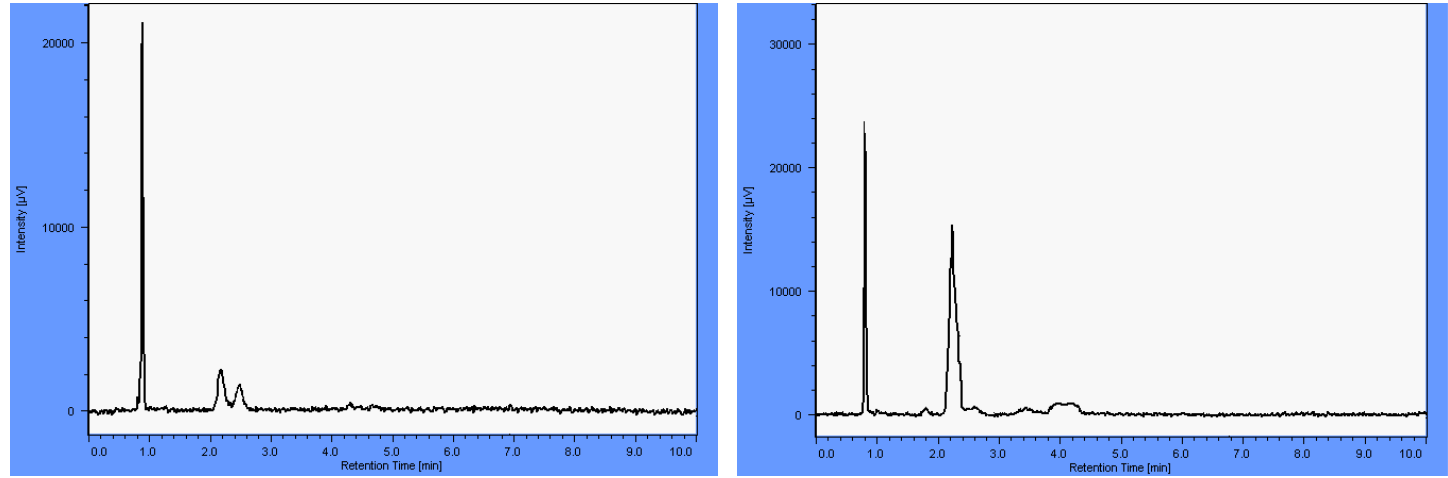

\begin{tabular}{ccc}
\hline Peak & Time & Area \\
\hline 1 & 2.15 & 142295 \\
2 & 2.55 & 792 \\
\hline
\end{tabular}


Chiral SFC analysis of racemic trans $\mathbf{5} \mathbf{u}$ (left) and enzymatically produced $\mathbf{5} \mathbf{u}$ product (right):
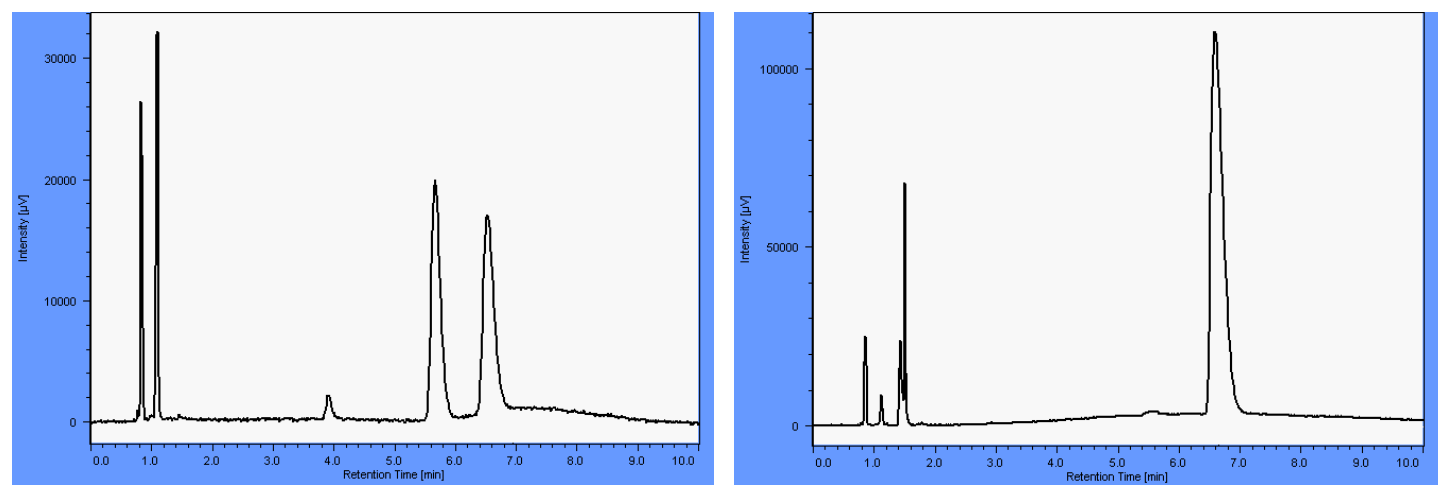

\begin{tabular}{ccc}
\hline Peak & Time & Area \\
\hline 1 & 5.75 & 1016392 \\
2 & 6.60 & 6743 \\
\hline
\end{tabular}

$>$ Chiral SFC analysis of racemic trans $\mathbf{5 v}$ (left) and enzymatically produced $\mathbf{5 v}$ product (right):
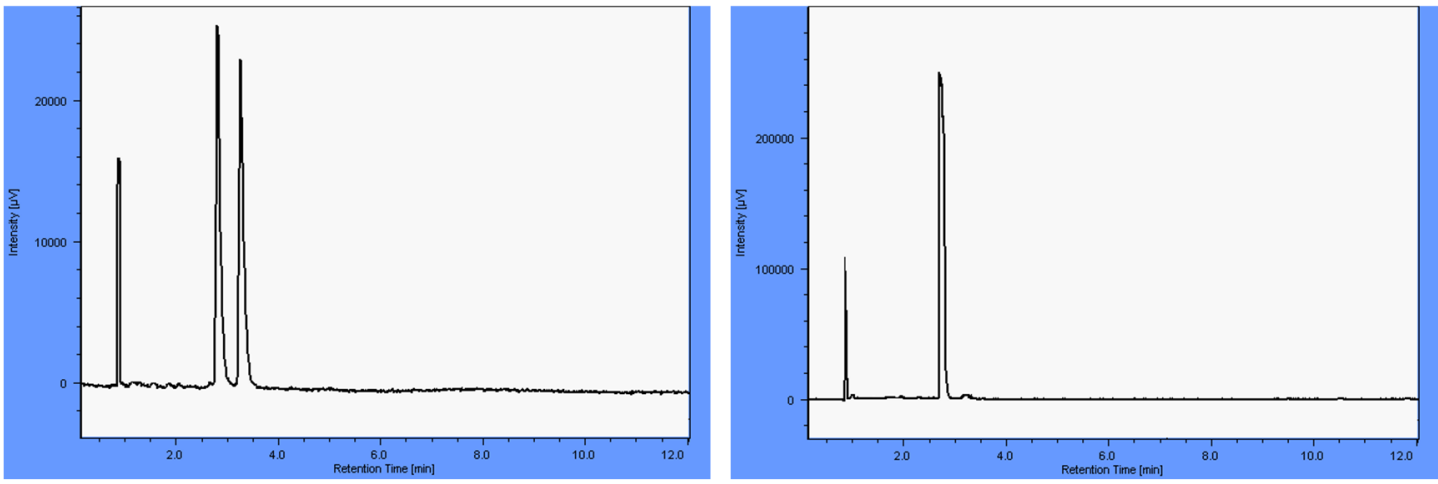

\begin{tabular}{ccc}
\hline Peak & Time & Area \\
\hline 1 & 2.80 & 5716780 \\
2 & 3.50 & 24712 \\
\hline
\end{tabular}


Chiral SFC analysis of racemic trans $\mathbf{5 w}$ (left) and enzymatically produced $\mathbf{5 w}$ product (right):
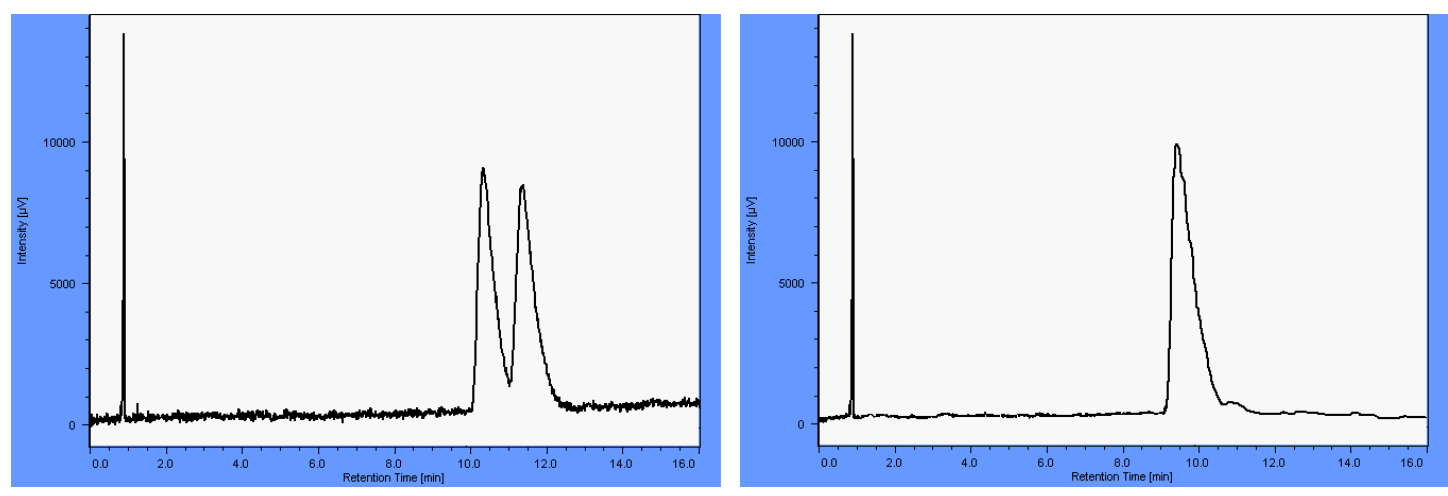

\begin{tabular}{ccc}
\hline Peak & Time & Area \\
\hline 1 & 10.5 & 241156 \\
2 & 11.5 & 6051 \\
\hline
\end{tabular}


Figure S10. Kinetic experiments for the cyclopropanation of styrene with EDA catalyzed by Mb(H64V,V68A,H93NMH)[Fe(DADP)] (3) (panel (a)) and Mb(H64V,V68A) (1) (panel (b)), each in the presence and in the absence of DMPO. Reaction conditions: $400 \mu \mathrm{L}$ scale in KPi buffer (pH 7.0, 10\% DMF) $5 \mu \mathrm{M}$ of protein, $10 \mathrm{mM}$ styrene (from $0.4 \mathrm{M}$ stock solution in DMF), $20 \mathrm{mM}$ EDA (from $0.8 \mathrm{M}$ stock solution in DMF), $100 \mathrm{mM}$ of DMPO (from $1 \mathrm{M}$ stock solution in DMF) and $10 \mathrm{mM} \mathrm{Na} \mathrm{S}_{2} \mathrm{O}_{4}$. At regular intervals $20 \mu \mathrm{L}$ of solution were collected and quenched with $50 \mu \mathrm{L}$ of $0.1 \mathrm{M} \mathrm{HCl}$. Aliquots were analyzed as described in the experimental details.

a) $\mathrm{Mb}(\mathrm{H} 64 \mathrm{~V}, \mathrm{~V} 68 \mathrm{~A}, \mathrm{H} 93 \mathrm{NMH})[\mathrm{Fe}(\mathrm{DADP})]$-catalyzed cyclopropanation reaction:

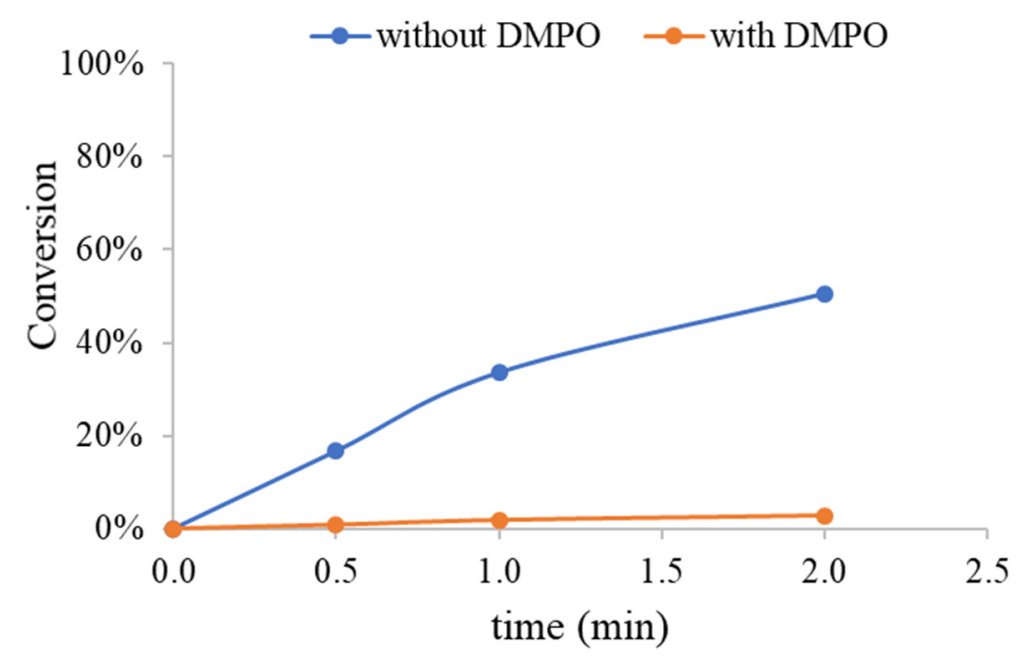

b) $\mathrm{Mb}(\mathrm{H} 64 \mathrm{~V}, \mathrm{~V} 68 \mathrm{~A})$-catalyzed cyclopropanation reaction:

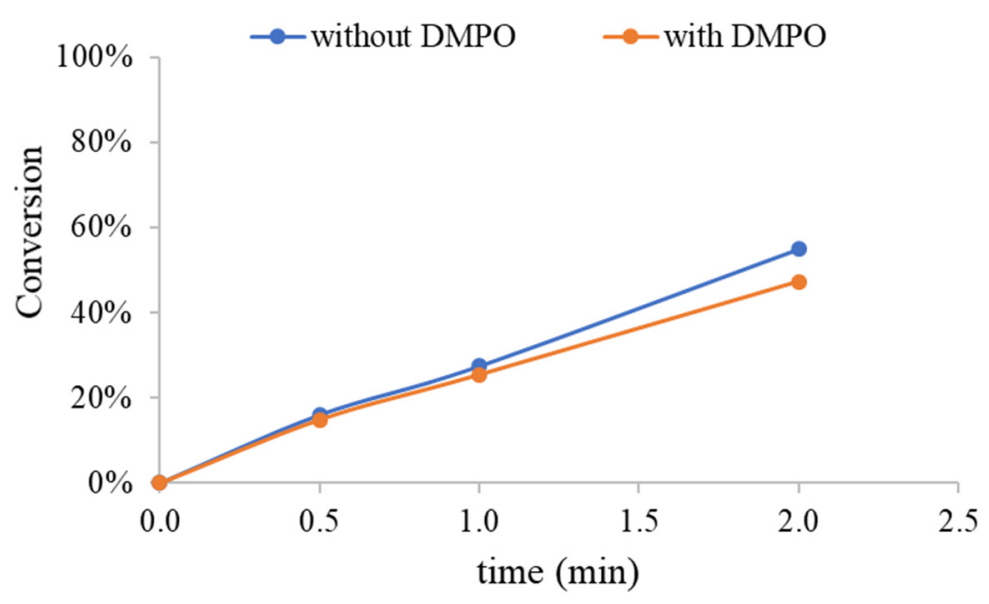




\section{Experimental Procedures}

Analytical Methods. Gas chromatography (GC) analyses were carried out using a Shimadzu GC-2010 gas chromatograph equipped with a FID detector, and a Cyclosil-B column (30 m x $0.25 \mathrm{~mm}$ x $0.25 \mu \mathrm{m}$ film). Separation method for cyclopropanation reactions: $1 \mu \mathrm{L}$ injection, injector temp.: $140{ }^{\circ} \mathrm{C}$, detector temp: $300{ }^{\circ} \mathrm{C}$. Gradient: column temperature set at $140{ }^{\circ} \mathrm{C}$ for $3 \mathrm{~min}$, then to $160^{\circ} \mathrm{C}$ at $1.8^{\circ} \mathrm{C} / \mathrm{min}$, then to $165^{\circ} \mathrm{C}$ at $1.0^{\circ} \mathrm{C} / \mathrm{min}$, then to $245^{\circ} \mathrm{C}$ at $25^{\circ} \mathrm{C} / \mathrm{min}$. Total run time was $28.31 \mathrm{~min}$. Calibration curves for the different cyclopropane products were constructed using pure racemic standards. All measurements were performed at least in duplicate. For enantioselectivity determination, the samples were analysed by SFC using a chiral column and an isocratic solvent system with the indicated modifier in liquid $\mathrm{CO}_{2}$ at an elution rate of 4 $\mathrm{mL} / \mathrm{min}$ and detected at $\lambda=220 \mathrm{~nm}$. Compounds $\mathbf{5 b}$-d were analysed using Daicel Chiralpak IC column and $1 \%$ of iPrOH. Compounds 5e, 5g, and 5p-q were analysed using Daicel Chiralpak IC column and 2\% of a mixture of 50\% $\mathrm{iPrOH}$ and $50 \%$ hexane. Compounds $\mathbf{5 f}, \mathbf{5 h}$ and $\mathbf{5 n}$ were analysed using a Daicel Chiralpak IA column and $2 \%$ of a mixture of $10 \% \mathrm{iPrOH}$ in hexane. Compound $\mathbf{5 i}$ was analysed using a Daicel Chiralpak IF column and 1\% of iPrOH. Compound $\mathbf{5 j}$ was analysed using a Daicel Chiralpak IB column and $\mathbf{1 0 0 \%}$ of $\mathrm{CO}_{2}$. Compounds $\mathbf{5 k}$ and $\mathbf{5 m - u}$ were analysed using Daicel Chiralpak IF column and $2 \%$ of iPrOH. Compounds 5s-t were analysed using Daicel Chiralpak IB and $2 \%$ of a mixture of $10 \%$ iPrOH in hexane. Compounds 5w was analysed using Diacel Chiralpak IB column and 5\% of a mixture of a mixture of $10 \% \mathrm{iPrOH}$ in hexane. Compound $\mathbf{5 v}$ was analysed using Daicel Chiralpak IB column and 10\% of $\mathrm{iPrOH}$.

\section{Synthetic Procedures}

\section{Synthesis of iron 2,4-diacetyldeuteroporphyrin IX chloride}

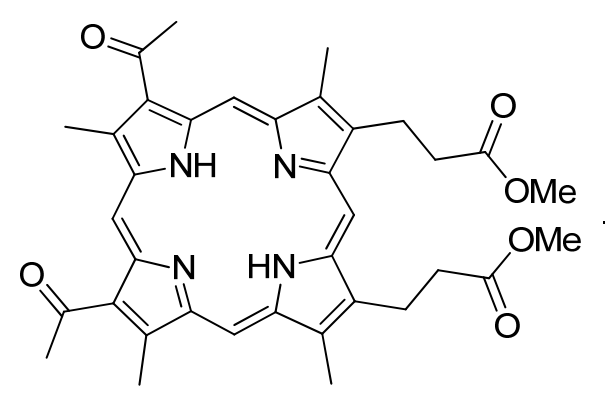

1) $\mathrm{FeCl}_{2} 4 \mathrm{H}_{2} \mathrm{O}$, $\mathrm{CH}_{3} \mathrm{CN} / \mathrm{CHCl}_{3}$, reflux

2) $\mathrm{KOH}, \mathrm{MeOH}$, r.t.

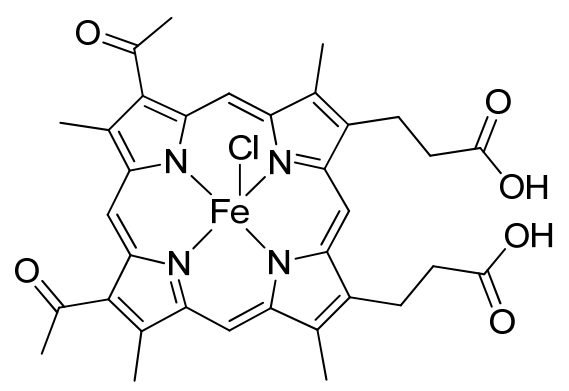

In a flame-dried $50 \mathrm{~mL}$ round-bottom flask, 2,4-diacetyldeuteroporphyrin IX dimethyl ester $\left(50 \mathrm{mg}, 8.0 \cdot 10^{-}\right.$ $\left.{ }^{5} \mathrm{~mol}\right)$ and $\mathrm{FeCl}_{2} \cdot 4 \mathrm{H}_{2} \mathrm{O}\left(0.10 \mathrm{~g}, 8.0 \cdot 10^{-4} \mathrm{~mol}\right)$ were dissolved in anhydrous THF $(20 \mathrm{~mL})$ under argon and the reaction was refluxed for 24 hours. The solvent was evaporated to dryness under reduced pressure and the crude was recovered with $\mathrm{CH}_{2} \mathrm{Cl}_{2}(10 \mathrm{~mL})$ and washed with $\mathrm{H}_{2} \mathrm{O}(10 \mathrm{~mL}$, three times). The combined organic phase was dried over $\mathrm{MgSO}_{4}$, filtered and the solvent was evaporated to dryness to give the iron 
2,4-diacetyldeuteroporphyrin IX dimethyl ester (47 mg, 7.6 $\left.10^{-5} \mathrm{~mol}, 95 \%\right)$ which was dissolved in a solution of THF $(5.0 \mathrm{~mL}), \mathrm{MeOH}(2.0 \mathrm{~mL})$ and $\mathrm{H}_{2} \mathrm{O}(2.0 \mathrm{~mL})$ with potassium hydroxide $\left(0.10 \mathrm{~g}, 1.8 \cdot 10^{-3}\right.$ mol). The reaction mixture was stirred at room temperature for 2 hours and then filtered obtaining the product as a dark solid (36 mg, 70\% yield).

UV-vis $\left(\mathrm{CH}_{2} \mathrm{Cl}_{2}\right): \lambda_{\max }(\varepsilon)=644$ (3192.7), 540 (6271.4), 513 (6613.4), $415 \mathrm{~nm}$ (43101.5). MS: $m / z=648.2$ $[\mathrm{M}-\mathrm{Cl}]$

\section{Synthesis of phenylacetylene- $d_{1}$}

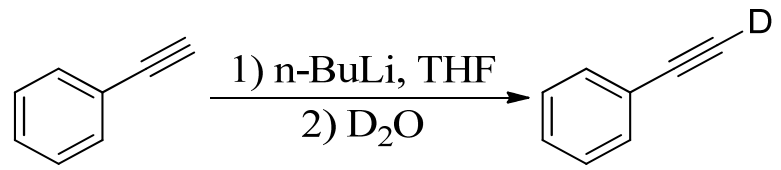

In a flame-dried $125 \mathrm{~mL}$ round-bottom flask, phenylacetylene $\left(3.3 \mathrm{~mL}, 3.0 \cdot 10^{-2} \mathrm{~mol}\right)$ was dissolved in anhydrous THF $(20 \mathrm{~mL})$ and cooled at $0^{\circ} \mathrm{C}$ under argon. $n$-Butyllithium $\left(2.5 \mathrm{M}\right.$ in hexane, $15 \mathrm{~mL}, 3.9 \cdot 10^{-2}$ mol) was added dropwise via a gastight syringe over $15 \mathrm{~min}$. The reaction mixture was stirred at $0^{\circ} \mathrm{C}$ for 1 hour, then $\mathrm{D}_{2} \mathrm{O}(3.0 \mathrm{~mL})$ was added slowly. The resulting mixture was stirred overnight at room temperature. The crude reaction was passed through a pad of anhydrous $\mathrm{MgSO}_{4}$, using a medium-porosity fritted-glass funnel and rinse with pentane $(10 \mathrm{~mL}$, three times). The solvent was evaporated under reduced pressure to afford phenylacetylene- $d_{1}$ as yellowish oil $(2.7 \mathrm{~g}, 89 \%)$. The collected data are in accordance with those reported in literature. ${ }^{[2]}$

${ }^{1} \mathbf{H}$ NMR $\left(500 \mathrm{MHz}, \mathrm{CDCl}_{3}\right): \delta$ 7.49-7.47 (m, 2H), 7.34-7.28 ppm (m, 3H). ${ }^{13} \mathbf{C} \mathbf{~ N M R}\left(125 \mathrm{MHz}, \mathrm{CDCl}_{3}\right)$ : $\delta 132.1,128.8,128.3,122.2,83.3(\mathrm{t}, J=7.5 \mathrm{~Hz}), 77.3 \mathrm{ppm}(\mathrm{t}, J=38.3 \mathrm{~Hz})$.

\section{Synthesis of $c i s$ - $\beta$-deuterostyrene $(d-4 a)$}

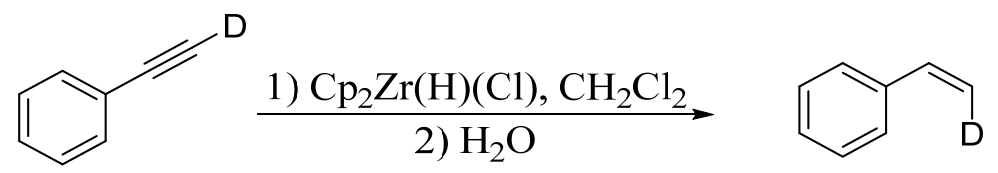

In a flame-dried $50 \mathrm{~mL}$ round-bottom flask, zircocene hydrochloride (Schwartz' reagent) (1.4 g, 5.6.10³ mol) was purged with argon for $1 \mathrm{~min}$, then anhydrous $\mathrm{CH}_{2} \mathrm{Cl}_{2}(14 \mathrm{~mL})$ was added and the reaction mixture was cooled at $0^{\circ} \mathrm{C}$. Phenylacetylene- $d_{1}\left(0.57 \mathrm{~mL}, 5.0 \cdot 10^{-3} \mathrm{~mol}\right)$ was added via syringe and the reaction was stirred at room temperature in the dark for 2 hours. Water $(1.0 \mathrm{~mL})$ was added, and the reaction mixture was stirred for an additional 2 hours. The resulting mixture was dried over $\mathrm{MgSO}_{4}$, filtered and the resulting suspension was passed through a silica gel pad (eluent: pentane). The filtrate was concentrated under reduced pressure to afford cis- $\beta$-deuterostyrene as a light-yellow oil $(0.41 \mathrm{~g}, 55 \%)$. Note: to avoid 
substantial loss of the volatile product, a trace amount of solvent was not removed. The collected data are in accordance with those reported in literature. ${ }^{[2]}$

${ }^{1}$ H NMR (500 MHz, $\left.\mathrm{CDCl}_{3}\right): \delta 7.3(\mathrm{~d}, J=7.5 \mathrm{~Hz}, 2 \mathrm{H}), 7.35(\mathrm{t}, J=7.4 \mathrm{~Hz}, 2 \mathrm{H}), 7.27(\mathrm{~m}, 1 \mathrm{H}), 6.73(\mathrm{dt}, J=10.8$ $\mathrm{Hz}, 2.1 \mathrm{~Hz}, 1 \mathrm{H}), 5.25 \mathrm{ppm}(\mathrm{d}, J=10.9 \mathrm{~Hz}, 1 \mathrm{H}) .{ }^{13} \mathbf{C} \mathbf{N M R}\left(125 \mathrm{MHz}, \mathrm{CDCl}_{3}\right): \delta 137.6,136.8,128.5,127.8$, $126.2,113.7 \mathrm{ppm}(\mathrm{t}, J=23.6 \mathrm{~Hz})$.

\section{Synthesis of racemic standards}

Procedure A: in a $10 \mathrm{~mL}$ flame-dried round-bottom flask, $\mathrm{Rh}_{2}(\mathrm{OAc})_{4}\left(1.4 \cdot 10^{-5} \mathrm{~mol}\right)$ and alkane $\left(3.4 \cdot 10^{-3}\right.$ mol) were dissolved in anhydrous $\mathrm{CH}_{2} \mathrm{Cl}_{2}(2.0 \mathrm{~mL})$ under argon. A solution of EDA $\left(6.8 \cdot 10^{-4} \mathrm{~mol}\right)$ in $\mathrm{CH}_{2} \mathrm{Cl}_{2}(4.0 \mathrm{~mL})$ was added dropwise via syringe pump over $1 \mathrm{~h}$. Upon full addition of EDA, the reaction was stirred at room temperature overnight. The solvent was then removed under reduced pressure, and the crude reaction mixture was purified by flash chromatography (silica gel, hexane:AcOEt 99:1). The cyclopropanation products were obtained as their racemic cis and trans isomers.

Procedure B: In a $20 \mathrm{~mL}$ flame-dried round-bottom flask, copper (II) triflate $\left(1.4 \cdot 10^{-5} \mathrm{~mol}\right)$ and phenyl vinyl sulfide $\left(2.6 \cdot 10^{-3} \mathrm{~mol}\right)$ were dissolved in $\mathrm{CHCl}_{3}(7.0 \mathrm{~mL})$ under argon. A solution of EDA $\left(2.2 \cdot 10^{-3}\right.$ mol) in $\mathrm{CHCl}_{3}(7.0 \mathrm{~mL})$ was added dropwise via syringe pump over $1 \mathrm{~h}$ and stirred at room temperature overnight. The solvent was removed under reduced pressure, and the crude product was purified by flash chromatography (silica gel, hexane:AcOEt 98:2). The product was obtained as its racemic cis and trans isomers.

Procedure C: in a $10 \mathrm{~mL}$ flame-dried round-bottom flask, $\mathrm{Cu}(\mathrm{I})\left(\mathrm{CF}_{3} \mathrm{SO}_{3}\right)$ toluene complex $\left(5.6 \cdot 10^{-5} \mathrm{~mol}\right)$ and $\mathrm{N}$-vinyl pyrrolidone $\left(2.25 \cdot 10^{-3} \mathrm{~mol}\right)$ were dissolved in anhydrous $\mathrm{CH}_{2} \mathrm{Cl}_{2}(2.0 \mathrm{~mL})$ under argon. A solution of EDA $\left(8.9 \cdot 10^{-3} \mathrm{~mol}\right)$ in $\mathrm{CH}_{2} \mathrm{Cl}_{2}(4.0 \mathrm{~mL})$ was added dropwise via syringe pump over $1 \mathrm{~h}$. Upon full addition of EDA, the reaction was stirred at room temperature overnight. The solvent was then removed under reduced pressure, and the crude reaction mixture was purified by flash chromatography (silica gel, from hexane:AcOEt 7:3 to AcOEt). The cyclopropanation product was obtained as its racemic trans isomers. 


\section{Compound Characterization Data}

Ethyl 2-phenylcyclopropane-1-carboxylate (5a)

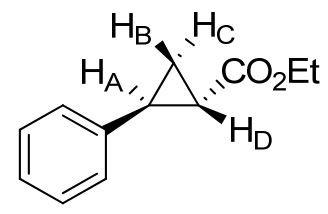

Following procedure A, trans isomer 5a was isolated as colorless oil (78\% yield). The analytical data are in accord with those reported in literature. ${ }^{[3]}$

${ }^{1} \mathbf{H}$ NMR (400 MHz, $\left.\mathrm{CDCl}_{3}\right): \delta 7.28\left(\mathrm{t}, 2 \mathrm{H}, J=7.5 \mathrm{~Hz}, \mathrm{H}_{\mathrm{Ar}}\right), 7.20\left(\mathrm{t}, 1 \mathrm{H}, J=7.3 \mathrm{~Hz}, \mathrm{H}_{\mathrm{Ar}}\right), 7.10(\mathrm{~d}, 2 \mathrm{H}, J=7.3$ $\left.\mathrm{Hz}, \mathrm{H}_{\mathrm{Ar}}\right), 4.18\left(\mathrm{q}, 2 \mathrm{H}, J=7.1 \mathrm{~Hz}, O \mathrm{CH}_{2}\right), 2.52\left(\mathrm{ddd}, 1 \mathrm{H}, J_{\mathrm{A}-\mathrm{C}}=9.1, J_{\mathrm{A}-\mathrm{B}}=6.4, J_{\mathrm{A}-\mathrm{D}}=4.2 \mathrm{~Hz}, \mathrm{H}_{\mathrm{A}}\right), 1.91(\mathrm{ddd}$, $\left.1 \mathrm{H}, J_{\mathrm{D}-\mathrm{B}}=8.5, J_{\mathrm{D}-\mathrm{C}}=5.2, J_{\mathrm{D}-\mathrm{A}}=4.3 \mathrm{~Hz}, \mathrm{H}_{\mathrm{D}}\right), 1.60\left(\mathrm{ddd}, 1 \mathrm{H}, J_{\mathrm{C}-\mathrm{A}}=9.4, J_{\mathrm{C}-\mathrm{D}}=4.8 \mathrm{~Hz},{ }^{2} J_{\mathrm{C}-\mathrm{B}}=4.8 \mathrm{~Hz}, \mathrm{H}_{\mathrm{C}}\right), 1.33$ $\left(\mathrm{ddd}, 1 \mathrm{H}, J_{\mathrm{B}-\mathrm{D}}=8.4, J_{\mathrm{B}-\mathrm{A}}=6.5 \mathrm{~Hz},{ }^{2} J_{\mathrm{B}-\mathrm{C}}=4.5 \mathrm{~Hz}, \mathrm{H}_{\mathrm{B}}\right), 1.28 \mathrm{ppm}\left(\mathrm{t}, 3 \mathrm{H}, J=7.1 \mathrm{~Hz}, \mathrm{CH}_{3}\right) .{ }^{13} \mathbf{C ~ N M R}(100 \mathrm{MHz}$, $\left.\mathrm{CDCl}_{3}\right): \delta 173.2,140.0,128.3,126.3,126.0,60.6,26.1,24.1,17.0,14.2 \mathrm{ppm}$.

\section{Ethyl 2-(2-methyl)phenylcyclopropane-1-carboxylate (5b)}<smiles>CCOC(=O)[C@]1(C)[C@@H](C)[C@@]1(C)c1ccccc1C</smiles>

Following procedure $\mathbf{A}$, trans isomer $\mathbf{5 b}$ was isolated as colorless oil (76\% yield). The analytical data are in accord with those reported in literature. ${ }^{[3]}$

${ }^{1}$ H NMR (400 MHz, $\left.\mathrm{CDCl}_{3}\right): \delta 7.16\left(\mathrm{~m}, 3 \mathrm{H}, \mathrm{H}_{\mathrm{Ar}}\right), 7-01-6.99\left(\mathrm{~m}, 1 \mathrm{H}, \mathrm{H}_{\mathrm{Ar}}\right), 4.23\left(\mathrm{q}, 2 \mathrm{H}, J=7.6 \mathrm{~Hz}, O \mathrm{CH}_{2}\right)$, $2.51\left(\mathrm{ddd}, 1 \mathrm{H}, J_{\mathrm{A}-\mathrm{C}}=9.1, J_{\mathrm{A}-\mathrm{B}}=6.7, J_{\mathrm{A}-\mathrm{D}}=4.2 \mathrm{~Hz}, \mathrm{H}_{\mathrm{A}}\right), 2.38\left(\mathrm{~s}, 3 \mathrm{H}, \mathrm{CH}_{3}\right), 1.78\left(\mathrm{ddd}, 1 \mathrm{H}, J_{\mathrm{D}-\mathrm{B}}=8.8, J_{\mathrm{D}-\mathrm{C}}=4.7\right.$, $\left.J_{\mathrm{D}-\mathrm{A}}=4.1 \mathrm{~Hz}, \mathrm{H}_{\mathrm{D}}\right), 1.56\left(\mathrm{ddd}, 1 \mathrm{H}, J_{\mathrm{C}-\mathrm{A}}=9.1, J_{\mathrm{C}-\mathrm{D}}=4.6 \mathrm{~Hz},{ }^{2} J_{\mathrm{C}-\mathrm{B}}=4.6 \mathrm{~Hz}, \mathrm{H}_{\mathrm{C}}\right), 1.31-1.28 \mathrm{ppm}\left(\mathrm{m}, 4 \mathrm{H}, \mathrm{CH}_{3}\right.$ and $\left.\mathrm{H}_{\mathrm{B}}\right) .{ }^{13} \mathrm{C}$ NMR $\left(100 \mathrm{MHz}, \mathrm{CDCl}_{3}\right): \delta 173.8,138.0,137.8,129.8,126.7,125.8,60.6,24.6,22.3,19.5,15.3$, $14.3 \mathrm{ppm}$.

\section{Ethyl 2-(3-methyl)phenylcyclopropane-1-carboxylate (5c)}

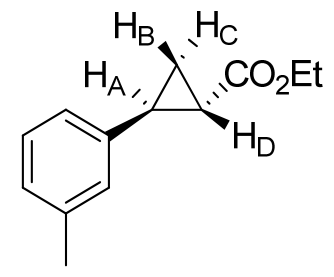

Following procedure A, trans isomer $\mathbf{5 c}$ was isolated as colorless oil ( $82 \%$ yield). The analytical data are in accord with those reported in literature. ${ }^{[3]}$ 
${ }^{1}$ H NMR (400 MHz, $\left.\mathrm{CDCl}_{3}\right): \delta 7.17\left(\mathrm{t}, 1 \mathrm{H}, J=7.7 \mathrm{~Hz}, \mathrm{H}_{\mathrm{Ar}}\right), 7.02\left(\mathrm{~d}, 1 \mathrm{H}, J=7.5 \mathrm{~Hz}, \mathrm{H}_{\mathrm{Ar}}\right), 6.93\left(\mathrm{~s}, 1 \mathrm{H}, \mathrm{H}_{\mathrm{Ar}}\right)$, $6.90\left(\mathrm{~d}, 2 \mathrm{H}, J=7.7 \mathrm{~Hz}, \mathrm{H}_{\mathrm{Ar}}\right), 4.18\left(\mathrm{q}, 2 \mathrm{H}, J=7.1 \mathrm{~Hz}, O \mathrm{CH}_{2}\right), 2.49\left(\mathrm{ddd}, 1 \mathrm{H}, J_{\mathrm{A}-\mathrm{C}}=9.5, J_{\mathrm{A}-\mathrm{B}}=6.5, J_{\mathrm{A}-\mathrm{D}}=4.2 \mathrm{~Hz}\right.$, $\left.\mathrm{H}_{\mathrm{A}}\right), 2.33\left(\mathrm{~s}, 3 \mathrm{H}, \mathrm{CH}_{3}\right), 1.90\left(\mathrm{ddd}, 1 \mathrm{H}, J_{\mathrm{D}-\mathrm{B}}=8.5, J_{\mathrm{D}-\mathrm{C}}=4.9, J_{\mathrm{D}-\mathrm{A}}=4.2 \mathrm{~Hz}, \mathrm{H}_{\mathrm{D}}\right), 1.59\left(\mathrm{ddd}, 1 \mathrm{H}, J_{\mathrm{C}-\mathrm{A}}=9.6, J_{\mathrm{C}-}\right.$ $\left.\mathrm{D}=4.9 \mathrm{~Hz},{ }^{2} J_{\mathrm{C}-\mathrm{B}}=4.9 \mathrm{~Hz}, \mathrm{H}_{\mathrm{C}}\right), 1.31 \mathrm{ppm}\left(\mathrm{ddd}, 1 \mathrm{H}, J_{\mathrm{B}-\mathrm{D}}=8.4, J_{\mathrm{B}-\mathrm{A}}=6.5 \mathrm{~Hz},{ }^{2} J_{\mathrm{B}-\mathrm{C}}=4.6 \mathrm{~Hz}, \mathrm{H}_{\mathrm{B}}\right), 1.29 \mathrm{ppm}(\mathrm{t}, 3 \mathrm{H}$, $\left.J=7.1 \mathrm{~Hz}, \mathrm{CH}_{3}\right) .{ }^{13} \mathbf{C}$ NMR $\left(100 \mathrm{MHz}, \mathrm{CDCl}_{3}\right): \delta 173.4,140.0,138.0,128.3,127.2,127.0,123.1,60.6$, 26.1, 24.1, 21.3, 16.9, $14.3 \mathrm{ppm}$.

\section{Ethyl 2-(4-methyl)phenylcyclopropane-1-carboxylate (5d)}

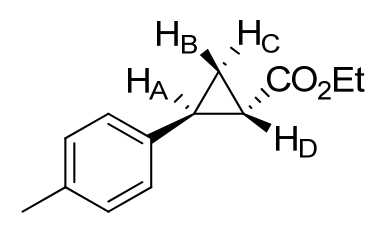

Following procedure A, trans isomer $\mathbf{5 d}$ was isolated as colorless oil (62\% yield). The analytical data are in accord with those reported in literature. ${ }^{[3]}$

${ }^{1} \mathbf{H}$ NMR (400 MHz, $\left.\mathrm{CDCl}_{3}\right): \delta 7.11\left(\mathrm{~d}, 2 \mathrm{H}, J=7.6 \mathrm{~Hz}, \mathrm{H}_{\mathrm{Ar}}\right), 7.01\left(\mathrm{~d}, 2 \mathrm{H}, J=7.6 \mathrm{~Hz}, \mathrm{H}_{\mathrm{Ar}}\right), 4.21$ (q, 2H, J=7.2 $\left.\mathrm{Hz}, O \mathrm{CH}_{2}\right), 2.50\left(\mathrm{ddd}, 1 \mathrm{H}, J_{\mathrm{A}-\mathrm{C}}=9.1, J_{\mathrm{A}-\mathrm{B}}=6.4, J_{\mathrm{A}-\mathrm{D}}=4.2 \mathrm{~Hz}, \mathrm{H}_{\mathrm{A}}\right), 2.32\left(\mathrm{~s}, 3 \mathrm{H}, \mathrm{CH}_{3}\right), 1.92\left(\mathrm{ddd}, 1 \mathrm{H}, J_{\mathrm{D}-\mathrm{B}}=8.5\right.$, $\left.J_{\mathrm{D}-\mathrm{C}}=4.9, J_{\mathrm{D}-\mathrm{A}}=4.2 \mathrm{~Hz}, \mathrm{H}_{\mathrm{D}}\right), 1.58\left(\mathrm{ddd}, 1 \mathrm{H}, J_{\mathrm{C}-\mathrm{A}}=9.4, J_{\mathrm{C}-\mathrm{D}}=4.9 \mathrm{~Hz},{ }^{2} J_{\mathrm{C}-\mathrm{B}}=4.9 \mathrm{~Hz}, \mathrm{H}_{\mathrm{C}}\right), 1.31-1.27 \mathrm{ppm}(\mathrm{m}$, $4 \mathrm{H}, \mathrm{H}_{\mathrm{B}}$ and $\left.\mathrm{CH}_{3}\right) .{ }^{13} \mathbf{C} \mathbf{N M R}\left(100 \mathrm{MHz}, \mathrm{CDCl}_{3}\right): \delta 173.5,137.0,136.0,129.1,126.1,60.6,25.9,24.0,20.9$, $16.9,14.2 \mathrm{ppm}$.

\section{Ethyl 2-(4-methoxy)phenylcyclopropane-1-carboxylate (5e)}

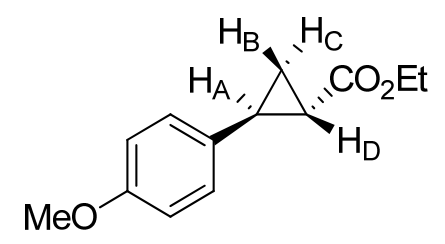

Following procedure A, trans isomer $\mathbf{5 e}$ was isolated as colorless oil ( $81 \%$ yield). The analytical data are in accord with those reported in literature. ${ }^{[3]}$

${ }^{1}$ H NMR (400 MHz, $\left.\mathrm{CDCl}_{3}\right): \delta 7.03\left(\mathrm{~d}, 2 \mathrm{H}, J=8.4 \mathrm{~Hz}, \mathrm{H}_{\mathrm{Ar}}\right), 6.82\left(\mathrm{~d}, 2 \mathrm{H}, J=8.4 \mathrm{~Hz}, \mathrm{H}_{\mathrm{Ar}}\right), 4.18(\mathrm{q}, 2 \mathrm{H}, J=7.2$ $\left.\mathrm{Hz}, O \mathrm{CH}_{2}\right), 3.76\left(\mathrm{~s}, 3 \mathrm{H}, \mathrm{CH}_{3}\right), 2.47\left(\mathrm{ddd}, 1 \mathrm{H}, J_{\mathrm{A}-\mathrm{C}}=9.2, J_{\mathrm{A}-\mathrm{B}}=6.4, J_{\mathrm{A}-\mathrm{D}}=4.2 \mathrm{~Hz}, \mathrm{H}_{\mathrm{A}}\right), 1.82\left(\mathrm{ddd}, 1 \mathrm{H}, J_{\mathrm{D}-\mathrm{B}}=8.4\right.$, $\left.J_{\mathrm{D}-\mathrm{C}}=5.0, J_{\mathrm{D}-\mathrm{A}}=4.2 \mathrm{~Hz}, \mathrm{H}_{\mathrm{D}}\right), 1.56-1.52\left(\mathrm{~m}, 1 \mathrm{H}, \mathrm{H}_{\mathrm{C}}\right), 1.32\left(\mathrm{t}, 3 \mathrm{H}, J=7.2 \mathrm{~Hz}, \mathrm{CH}_{3}\right), 1.23 \mathrm{ppm}\left(\mathrm{ddd}, 1 \mathrm{H}, J_{\mathrm{B}-}\right.$ $\left.\mathrm{D}=8.4, J_{\mathrm{B}-\mathrm{A}}=6.5,{ }^{2} J_{\mathrm{B}-\mathrm{C}}=4.5 \mathrm{~Hz}, \mathrm{H}_{\mathrm{B}}\right) .{ }^{13} \mathbf{C} \mathbf{N M R}\left(100 \mathrm{MHz}, \mathrm{CDCl}_{3}\right): \delta 173.5,158.3,132.1,127.5,113.9,60.6$, $55.2,25.6,23.8,16.7,14.2 \mathrm{ppm}$. 
Ethyl 2-(4-fluoro)phenylcyclopropane-1-carboxylate (5f)<smiles>[2H]O[C@]1(C)[C@@H]([13CH2])[C@@]1([2H])c1ccc(F)cc1</smiles>

Following procedure A, trans isomer $\mathbf{5 f}$ was isolated as colorless oil (50\% yield). The analytical data are in accord with those reported in literature. ${ }^{[4]}$

${ }^{1} \mathbf{H}$ NMR $\left(400 \mathrm{MHz}, \mathrm{CDCl}_{3}\right): \delta$ 7.8-7.05 (m, 2H, $\left.\mathrm{H}_{\mathrm{Ar}}\right), 6.99-6.93\left(\mathrm{~m}, 2 \mathrm{H}, \mathrm{H}_{\mathrm{Ar}}\right), 4.17(\mathrm{q}, 2 \mathrm{H}, J=7.2 \mathrm{~Hz}$, $\left.O_{C H}\right), 2.53-2.48\left(\mathrm{~m}, 1 \mathrm{H}, \mathrm{H}_{\mathrm{A}}\right), 1.87-1.82\left(\mathrm{~m}, 1 \mathrm{H}, \mathrm{H}_{\mathrm{B}}\right), 1.61-1.56\left(\mathrm{~m}, 1 \mathrm{H}, \mathrm{CH}_{2}\right), 1.30-1.28\left(\mathrm{~m}, 1 \mathrm{H}, \mathrm{CH}_{2}\right)$, $1.28 \mathrm{ppm}\left(\mathrm{t}, 3 \mathrm{H}, J=7.2 \mathrm{~Hz}, \mathrm{CH}_{3}\right) .{ }^{13} \mathbf{C} \mathbf{N M R}\left(100 \mathrm{MHz}, \mathrm{CDCl}_{3}\right): \delta 173.3,163.1,159.9,135.7,127.8,127.7$, $115.4,115.1,60.7,25.4,24.0,17.0,14.2 \mathrm{ppm}$.

Ethyl 2-(4-chloro)phenylcyclopropane-1-carboxylate (5g)

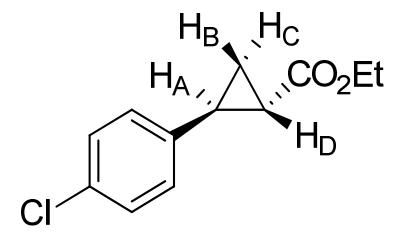

Following procedure A, trans isomer $\mathbf{5 g}$ was isolated as colorless oil (76\% yield). The analytical data are in accord with those reported in literature. ${ }^{[3]}$

${ }^{1} \mathbf{H}$ NMR (400 MHz, $\left.\mathrm{CDCl}_{3}\right): \delta 7.24\left(\mathrm{~d}, 2 \mathrm{H}, J=7.6 \mathrm{~Hz}, \mathrm{H}_{\mathrm{Ar}}\right), 7.02\left(\mathrm{~d}, 2 \mathrm{H}, J=7.2 \mathrm{~Hz}, \mathrm{H}_{\mathrm{Ar}}\right), 4.19$ (q, 2H, J=6.8

$\left.\mathrm{Hz}, O \mathrm{CH}_{2}\right), 2.48\left(\mathrm{ddd}, 1 \mathrm{H}, J_{\mathrm{A}-\mathrm{C}}=9.2, J_{\mathrm{A}-\mathrm{B}}=6.3, J_{\mathrm{A}-\mathrm{D}}=4.2 \mathrm{~Hz}, \mathrm{H}_{\mathrm{A}}\right), 1.84\left(\mathrm{ddd}, 1 \mathrm{H}, J_{\mathrm{D}-\mathrm{B}}=8.6, J_{\mathrm{D}-\mathrm{C}}=5.0, J_{\mathrm{D}-\mathrm{A}}=4.2\right.$ $\left.\mathrm{Hz}, \mathrm{H}_{\mathrm{D}}\right), 1.59\left(\mathrm{ddd}, 1 \mathrm{H}, J_{\mathrm{C}-\mathrm{A}}=9.2, J_{\mathrm{C}-\mathrm{D}}=5.0,{ }^{2} J_{\mathrm{C}-\mathrm{B}}=4.9 \mathrm{~Hz}, \mathrm{H}_{\mathrm{C}}\right), 1.29-1.23 \mathrm{ppm}\left(\mathrm{m}, 4 \mathrm{H}, \mathrm{H}_{\mathrm{B}}\right.$ and $\left.\mathrm{CH}_{3}\right) .{ }^{13} \mathrm{C}$ NMR (100 MHz, $\left.\mathrm{CDCl}_{3}\right): \delta$ 173.1, 138.6, 132.1, 128.5, 127.5, 60.8, 25.4, 24.1, 16.9, 14.2 ppm.

\section{Ethyl 2-(4-bromo)phenylcyclopropane-1-carboxylate (5h)}

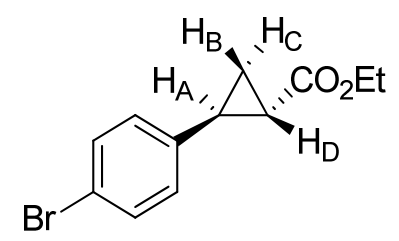

Following procedure A, trans isomer $\mathbf{5 h}$ was isolated as colorless oil (62\% yield). The analytical data are in accord with those reported in literature. ${ }^{[4]}$

${ }^{1}$ H NMR (400 MHz, $\left.\mathrm{CDCl}_{3}\right): \delta 7.39$ (d, 2H, $\left.J=8.7 \mathrm{~Hz}, \mathrm{H}_{\mathrm{Ar}}\right), 6.97$ (d, 2H, J=8.7 Hz, H $\left.\mathrm{Ar}_{\mathrm{Ar}}\right), 4.17$ (q, 2H, J=7.2 $\left.\mathrm{Hz}, O \mathrm{CH}_{2}\right), 2.47\left(\mathrm{ddd}, 1 \mathrm{H}, J_{\mathrm{A}-\mathrm{C}}=9.3, J_{\mathrm{A}-\mathrm{B}}=6.2, J_{\mathrm{A}-\mathrm{D}}=4.2 \mathrm{~Hz}, \mathrm{H}_{\mathrm{A}}\right), 1.87\left(\mathrm{ddd}, 1 \mathrm{H}, J_{\mathrm{D}-\mathrm{B}}=8.4, J_{\mathrm{D}-\mathrm{C}}=5.1, J_{\mathrm{D}-\mathrm{A}}=4.2\right.$ $\left.\mathrm{Hz}, \mathrm{H}_{\mathrm{D}}\right), 1.60\left(\mathrm{ddd}, 1 \mathrm{H}, J_{\mathrm{C}-\mathrm{A}}=9.4, J_{\mathrm{C}-\mathrm{D}}=4.9 \mathrm{~Hz},{ }^{2} J_{\mathrm{C}-\mathrm{B}}=4.9 \mathrm{~Hz}, \mathrm{H}_{\mathrm{C}}\right), 1.29\left(\mathrm{t}, 3 \mathrm{H}, J=7.2 \mathrm{~Hz}, \mathrm{CH}_{3}\right), 1.26-1.24$ 
$\operatorname{ppm}\left(\mathrm{m}, 1 \mathrm{H}, \mathrm{H}_{\mathrm{B}}\right) .{ }^{13} \mathbf{C} \mathbf{N M R}\left(100 \mathrm{MHz}, \mathrm{CDCl}_{3}\right): \delta 173.1,139.1,131.4,127.9,120.1,60.8,25.5,24.1,17.0$, $14.2 \mathrm{ppm}$.

Ethyl 2-methyl-2-phenylcyclopropane-1-carboxylate (5i)<smiles>CCO[C@H]1[C@@H](C)[C@]1(C)c1ccccc1</smiles>

Following procedure A, trans isomer $\mathbf{5 i}$ was isolated as colorless oil (73\% yield). The analytical data are in accord with those reported in literature. ${ }^{[3]}$

${ }^{1} \mathbf{H}$ NMR (400 MHz, $\left.\mathrm{CDCl}_{3}\right): \delta 7.30\left(\mathrm{~m}, 4 \mathrm{H}, \mathrm{H}_{\mathrm{Ar}}\right), 7.22-7.20\left(\mathrm{~m}, 1 \mathrm{H}, \mathrm{H}_{\mathrm{Ar}}\right), 4.23\left(\mathrm{q}, 2 \mathrm{H}, J=6.2 \mathrm{~Hz}, O \mathrm{CH}_{2}\right)$, $1.97\left(\mathrm{dd}, 1 \mathrm{H}, J_{\mathrm{A}-\mathrm{C}}=8.2, J_{\mathrm{A}-\mathrm{B}}=6.1 \mathrm{~Hz}, \mathrm{CH}\right), 1.54\left(\mathrm{~s}, 3 \mathrm{H}, \mathrm{CH}_{3}\right), 1.45\left(\mathrm{dd}, 1 \mathrm{H}, J_{\mathrm{B}-\mathrm{A}}=5.9 \mathrm{~Hz},{ }^{2} J_{\mathrm{B}-\mathrm{C}}=4.3 \mathrm{~Hz}, \mathrm{H}_{\mathrm{B}}\right)$, $1.41\left(\mathrm{dd}, 1 \mathrm{H}, J_{\mathrm{C}-\mathrm{A}}=8.2 \mathrm{~Hz},{ }^{2} J_{\mathrm{C}-\mathrm{B}}=4.5 \mathrm{~Hz}, \mathrm{H}_{\mathrm{B}}\right), 1.32-1.29 \mathrm{ppm}\left(\mathrm{m}, 3 \mathrm{H}, \mathrm{CH}_{3}\right) .{ }^{13} \mathbf{C} \mathbf{N M R}\left(100 \mathrm{MHz}, \mathrm{CDCl}_{3}\right)$ : $\delta 172.1,145.9,128.4,127.3,126.4,60.4,30.5,27.8,20.7,19.6,14.4$ ppm.

\section{Ethyl 2-(2-naphthalenyl)cyclopropane-1-carboxylate (5j)}<smiles>CCOC(=O)C1C[C@H]1c1ccc2ccccc2c1</smiles>

Following procedure A, trans isomer $\mathbf{5 j}$ was isolated as colorless oil (58\% yield). The analytical data are in accord with those reported in literature. ${ }^{[5]}$

${ }^{1} \mathbf{H}$ NMR $\left(400 \mathrm{MHz}, \mathrm{CDCl}_{3}\right): \delta 8.22\left(\mathrm{~d}, 1 \mathrm{H}, J=8.4 \mathrm{~Hz}, \mathrm{H}_{\mathrm{Ar}}\right), 7.88\left(\mathrm{~d}, 1 \mathrm{H}, J=8.0 \mathrm{~Hz}, \mathrm{H}_{\mathrm{Ar}}\right), 7.77(\mathrm{~d}, 1 \mathrm{H}, J=8.0$ $\left.\mathrm{Hz}, \mathrm{H}_{\mathrm{Ar}}\right), 7.61-7.52\left(\mathrm{~m}, 2 \mathrm{H}, \mathrm{H}_{\mathrm{Ar}}\right), 7.41\left(\mathrm{t}, 1 \mathrm{H}, J=8.0 \mathrm{~Hz}, \mathrm{H}_{\mathrm{Ar}}\right), 7.29\left(\mathrm{~d}, 1 \mathrm{H}, J=8 \mathrm{~Hz}, \mathrm{H}_{\mathrm{Ar}}\right), 4.32-4.26(\mathrm{~m}, 2 \mathrm{H}$, $\left.\mathrm{OCH}_{2}\right), 3.06-3.01(\mathrm{~m}, 1 \mathrm{H}, \mathrm{CH}), 1.99-1.95(\mathrm{~m}, 1 \mathrm{H}, \mathrm{CH}), 1.77-1.72\left(\mathrm{~m}, 1 \mathrm{H}, \mathrm{CH}_{2-\mathrm{A}}\right), 1.48-1.43\left(\mathrm{~m}, 1 \mathrm{H}, \mathrm{CH}_{2-}\right.$ в), $1.37 \mathrm{ppm}\left(\mathrm{t}, 3 \mathrm{H}, J=7.2 \mathrm{~Hz}, \mathrm{CH}_{3}\right) .{ }^{13} \mathbf{C} \mathbf{N M R}\left(100 \mathrm{MHz}, \mathrm{CDCl}_{3}\right): \delta 173.5,137.7,133.5,132.4,128.3$, $127.8,127.5,126.4,125.6,124.9,124.7,60.9,26.5,24.3,17.1,14.4 \mathrm{ppm}$.

Ethyl 2-(phenylthio)cyclopropane-1-carboxylate (5k)<smiles>[2H][C@H]1[C@@H](COCC)[C@]1(C)Sc1ccccc1</smiles>

Following procedure $\mathbf{B}$, trans isomer $\mathbf{5 k}$ was isolated as colorless oil (20\% yield). The analytical data are in accord with those reported in literature. ${ }^{[6]}$ 
${ }^{1}$ H NMR $\left(500 \mathrm{MHz}, \mathrm{CDCl}_{3}\right): \delta$ 7.29-7.24 (m, 4H, $\left.\mathrm{H}_{\mathrm{Ar}}\right), 7.21-7.15\left(\mathrm{~m}, 1 \mathrm{H}, \mathrm{H}_{\mathrm{Ar}}\right), 4.18-4.12\left(\mathrm{~m}, 2 \mathrm{H}, O_{2} \mathrm{CH}_{2}\right)$, $2.73\left(\mathrm{ddd}, 1 \mathrm{H}, J_{\mathrm{A}-\mathrm{C}}=7.9, J_{\mathrm{A}-\mathrm{B}}=5.6, J_{\mathrm{A}-\mathrm{D}}=3.7 \mathrm{~Hz}, \mathrm{H}_{\mathrm{A}}\right), 1.88\left(\mathrm{ddd}, 1 \mathrm{H}, J_{\mathrm{D}-\mathrm{B}}=8.4, J_{\mathrm{D}-\mathrm{C}}=5.2, J_{\mathrm{D}-\mathrm{A}}=3.7 \mathrm{~Hz}, \mathrm{H}_{\mathrm{D}}\right)$, $1.62\left(\mathrm{ddd}, 1 \mathrm{H}, J_{\mathrm{C}-\mathrm{A}}=8.0, J_{\mathrm{C}-\mathrm{D}}=5.1 \mathrm{~Hz},{ }^{2} J_{\mathrm{C}-\mathrm{B}}=4.9 \mathrm{~Hz}, \mathrm{H}_{\mathrm{C}}\right), 1.25\left(\mathrm{t}, 3 \mathrm{H}, J=7.1 \mathrm{~Hz}, \mathrm{CH}_{3}\right), 1.22-1.15 \mathrm{ppm}(\mathrm{m}$, $\left.1 \mathrm{H}, \mathrm{H}_{\mathrm{B}}\right) .{ }^{13} \mathbf{C}$ NMR $\left(125 \mathrm{MHz}, \mathrm{CDCl}_{3}\right): \delta 172.4,136.9,129.0,127.4,125.8,61.1,24.3,22.4,17.3,14.3$ ppm.

\section{Ethyl 2-phenoxycyclopropane-1-carboxylate (51)}<smiles>[2H][C@H]1[C@@H](Oc2ccccc2)[C@]1(C)[C@H](C)OCC</smiles>

Following procedure A, trans isomer $\mathbf{5 l}$ was isolated as colorless oil (28\% yield). The analytical data are in accord with those reported in literature. ${ }^{[6]}$

${ }^{1}$ H NMR $\left(500 \mathrm{MHz}, \mathrm{CDCl}_{3}\right): \delta 7.30\left(\mathrm{t}, 2 \mathrm{H}, J=7.6 \mathrm{~Hz}, \mathrm{H}_{\mathrm{Ar}}\right), 7.01\left(\mathrm{t}, 1 \mathrm{H}, J=7.3 \mathrm{~Hz}, \mathrm{H}_{\mathrm{Ar}}\right), 6.97(\mathrm{~d}, 2 \mathrm{H}, J=8.0$ $\left.\mathrm{Hz}, \mathrm{H}_{\mathrm{Ar}}\right), 4.28-4.13\left(\mathrm{~m}, 2 \mathrm{H}, O \mathrm{CH}_{2}\right), 4.07\left(\mathrm{ddd}, 1 \mathrm{H}, J_{\mathrm{A}-\mathrm{C}}=6.3, J_{\mathrm{A}-\mathrm{B}}=4.0, J_{\mathrm{A}-\mathrm{D}}=2.0 \mathrm{~Hz}, \mathrm{H}_{\mathrm{A}}\right), 1.94\left(\mathrm{ddd}, 1 \mathrm{H}, J_{\mathrm{D}-}\right.$ $\left.{ }_{\mathrm{B}}=9.6, J_{\mathrm{D}-\mathrm{C}}=6.2, J_{\mathrm{D}-\mathrm{A}}=1.9 \mathrm{~Hz}, \mathrm{H}_{\mathrm{D}}\right), 1.50\left(\mathrm{~m}, 1 \mathrm{H}, \mathrm{H}_{\mathrm{C}}\right), 1.42\left(\mathrm{ddd}, 1 \mathrm{H}, J_{\mathrm{B}-\mathrm{D}}=9.7, J_{\mathrm{B}-\mathrm{A}}=4.1 \mathrm{~Hz},{ }^{2} J_{\mathrm{B}-\mathrm{C}}=5.7 \mathrm{~Hz}\right.$, $\left.\mathrm{H}_{\mathrm{B}}\right), 1.30 \mathrm{ppm}\left(\mathrm{t}, 3 \mathrm{H}, J=7.1 \mathrm{~Hz}, \mathrm{CH}_{3}\right) .{ }^{13} \mathbf{C} \mathbf{N M R}\left(125 \mathrm{MHz}, \mathrm{CDCl}_{3}\right): \delta 172.2,158.1,129.7,121.8,115.0$, $61.0,57.3,21.8,15.8,14.4 \mathrm{ppm}$.

\section{Ethyl 2-(phenoxymethyl)cyclopropane-1-carboxylate (5m)}

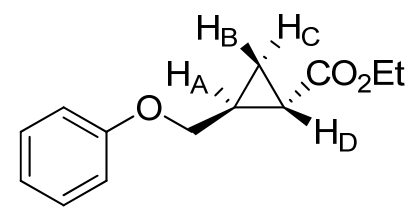

Following procedure A, trans isomer $\mathbf{5 m}$ was isolated as colorless oil. The analytical data are in accord with those reported in literature. ${ }^{[6]}$

${ }^{1}$ H NMR (500 MHz, $\left.\mathrm{CDCl}_{3}\right): \delta$ 7.28-7.18 (m, 2H, $\mathrm{H}_{\mathrm{Ar}}$ ), $6.91\left(\mathrm{~m}, 1 \mathrm{H}, \mathrm{H}_{\mathrm{Ar}}\right), 6.88-6.79\left(\mathrm{~m}, 2 \mathrm{H}, \mathrm{H}_{\mathrm{Ar}}\right), 4.14-$ $4.07\left(\mathrm{~m}, 2 \mathrm{H}, \mathrm{OCH}_{2}\right), 3.90\left(\mathrm{dd}, 1 \mathrm{H}, J=9.5,6.5 \mathrm{~Hz}, \mathrm{CH}_{2}\right), 3.84$ (dd, $\left.1 \mathrm{H}, J=9.9,6.4 \mathrm{~Hz}, \mathrm{CH}_{2}\right), 1.98-1.81$ (m, $1 \mathrm{H}, \mathrm{CH}), 1.75-1.64(\mathrm{~m}, 1 \mathrm{H}, \mathrm{CH}), 1.26-1.25(\mathrm{~m}, 1 \mathrm{H}, \mathrm{CH}), 1.24$ (t, 3H, J=6.6 Hz, $\left.\mathrm{CH}_{3}\right), 0.99-0.91 \mathrm{ppm}(\mathrm{m}$, $1 \mathrm{H}, \mathrm{CH}) .{ }^{13} \mathbf{C}$ NMR $\left(125 \mathrm{MHz}, \mathrm{CDCl}_{3}\right): \delta 229.5,173.7,158.8,129.6,121.1,114.8,69.3,60.8,21.2,18.7$, $14.4,13.0 \mathrm{ppm}$. 
Ethyl 2-(4-trifluoromethyl)phenylcyclopropane-1-carboxylate (5n)<smiles>CCO[C@H]1[C@@H]([13CH2])[C@H]1c1ccc(C(F)(F)F)cc1</smiles>

Following procedure A, trans isomer $\mathbf{5 n}$ was isolated as colorless oil (45\% yield). The analytical data are in accord with those reported in literature. ${ }^{[3]}$

${ }^{1} \mathbf{H}$ NMR (400 MHz, $\left.\mathrm{CDCl}_{3}\right): \delta 7.52\left(\mathrm{~d}, 2 \mathrm{H}, J=7.6 \mathrm{~Hz}, \mathrm{H}_{\mathrm{Ar}}\right), 7.19\left(\mathrm{~d}, 2 \mathrm{H}, J=8.0 \mathrm{~Hz}, \mathrm{H}_{\mathrm{Ar}}\right), 4.20$ (q, 2H, J=7.2 $\left.\mathrm{Hz}, O \mathrm{CH}_{2}\right), 2.53\left(\mathrm{ddd}, 1 \mathrm{H}, J_{\mathrm{A}-\mathrm{C}}=9.2, J_{\mathrm{A}-\mathrm{B}}=6.4, J_{\mathrm{A}-\mathrm{D}}=4.2 \mathrm{~Hz}, \mathrm{H}_{\mathrm{A}}\right), 1.92\left(\mathrm{ddd}, 1 \mathrm{H}, J_{\mathrm{D}-\mathrm{B}}=8.4, J_{\mathrm{D}-\mathrm{C}}=5.1, J_{\mathrm{D}-\mathrm{A}}=4.4\right.$ $\left.\mathrm{Hz}, \mathrm{H}_{\mathrm{D}}\right), 1.64\left(\mathrm{ddd}, 1 \mathrm{H}, J_{\mathrm{C}-\mathrm{A}}=9.5, J_{\mathrm{C}-\mathrm{D}}=5.1 \mathrm{~Hz},{ }^{2} J_{\mathrm{C}-\mathrm{B}}=5.1 \mathrm{~Hz}, \mathrm{H}_{\mathrm{C}}\right), 1.34\left(\mathrm{ddd}, 1 \mathrm{H}, J_{\mathrm{B}-\mathrm{D}}=8.6, J_{\mathrm{B}-\mathrm{A}}=6.5 \mathrm{~Hz},{ }^{2} J_{\mathrm{B}-}\right.$ $\left.\mathrm{C}=4.9 \mathrm{~Hz}, \mathrm{H}_{\mathrm{B}}\right), 1.29 \mathrm{ppm}\left(\mathrm{t}, 3 \mathrm{H}, J=7.1 \mathrm{~Hz}, \mathrm{CH}_{3}\right) .{ }^{13} \mathbf{C}$ NMR $\left(100 \mathrm{MHz}, \mathrm{CDCl}_{3}\right): \delta 172.8,144.3,126.4$, $125.3,60.9,25.6,24.4,17.2,14.2 \mathrm{ppm}$.

Ethyl 2-(4-nitro)phenylcyclopropane-1-carboxylate (5o)

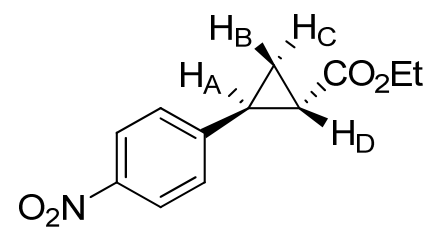

Following procedure A, trans isomer $\mathbf{5 0}$ was isolated as colorless oil. The analytical data are in accord with those reported in literature. ${ }^{[7]}$

${ }^{1}$ H NMR (500 MHz, $\left.\mathrm{CDCl}_{3}\right): \delta 8.13\left(\mathrm{~d}, 2 \mathrm{H}, J=8.8 \mathrm{~Hz}, \mathrm{H}_{\mathrm{Ar}}\right), 7.22\left(\mathrm{~d}, 2 \mathrm{H}, J=8.8 \mathrm{~Hz}, \mathrm{H}_{\mathrm{Ar}}\right), 4.22-4.13(\mathrm{~m}, 2 \mathrm{H}$, $\left.O \mathrm{CH}_{2}\right), 2.59\left(\mathrm{ddd}, 1 \mathrm{H}, J_{\mathrm{A}-\mathrm{C}}=9.2, J_{\mathrm{A}-\mathrm{B}}=6.2, J_{\mathrm{A}-\mathrm{D}}=4.2 \mathrm{~Hz}, \mathrm{H}_{\mathrm{A}}\right), 1.99\left(\mathrm{ddd}, 1 \mathrm{H}, J_{\mathrm{D}-\mathrm{B}}=8.8, J_{\mathrm{D}-\mathrm{C}}=5.4, J_{\mathrm{D}-\mathrm{A}}=4.3\right.$ $\left.\mathrm{Hz}, \mathrm{H}_{\mathrm{D}}\right), 1.72\left(\mathrm{ddd}, 1 \mathrm{H}, J_{\mathrm{C}-\mathrm{A}}=9.3, J_{\mathrm{C}-\mathrm{D}}=5.2,{ }^{2} J_{\mathrm{C}-\mathrm{B}}=5.1 \mathrm{~Hz}, \mathrm{H}_{\mathrm{C}}\right), 1.38\left(\mathrm{ddd}, 1 \mathrm{H}, J_{\mathrm{B}-\mathrm{D}}=8.6, J_{\mathrm{B}-\mathrm{A}}=6.3 \mathrm{~Hz},{ }^{2} J_{\mathrm{B}-}\right.$ $\left.\mathrm{C}=4.9 \mathrm{~Hz}, \mathrm{H}_{\mathrm{B}}\right), 1.28\left(\mathrm{t}, 3 \mathrm{H}, J=7.1 \mathrm{~Hz}, \mathrm{CH}_{3}\right) .{ }^{13} \mathbf{C} \mathbf{N M R}\left(125 \mathrm{MHz}, \mathrm{CDCl}_{3}\right): \delta 171.2,147.9,144.3,125.9$, $123.3,61.6,26.2,24.2,16.9,14.10 \mathrm{ppm}$.

\section{Ethyl 2-(3-nitro)phenylcyclopropane-1-carboxylate (5p)}<smiles>CCO[C@H]1[C@@H]([13CH2])[C@]1(C)c1cccc([N+](=O)[O-])c1</smiles>

Following procedure A, trans isomer $\mathbf{5 p}$ was isolated as colorless oil. The analytical data are in accord with those reported in literature. ${ }^{[8]}$ 
${ }^{1}$ H NMR (400 MHz, $\left.\mathrm{CDCl}_{3}\right): \delta 8.11-7.96\left(\mathrm{~m}, 1 \mathrm{H}, \mathrm{H}_{\mathrm{Ar}}\right), 7.91\left(\mathrm{dd}, J=1.4,0.9 \mathrm{~Hz}, 1 \mathrm{H}, \mathrm{H}_{\mathrm{Ar}}\right), 7.43(\mathrm{ddd}, 2 \mathrm{H}$, $\left.J=3.3,0.9,0.9 \mathrm{~Hz}, \mathrm{H}_{\mathrm{Ar}}\right), 4.17\left(\mathrm{q}, 2 \mathrm{H}, J=7.1 \mathrm{~Hz}, O \mathrm{CH}_{2}\right), 2.60\left(\mathrm{ddd}, 1 \mathrm{H}, J_{\mathrm{A}-\mathrm{C}}=9.3, J_{\mathrm{A}-\mathrm{B}}=6.4, J_{\mathrm{A}-\mathrm{D}}=4.2 \mathrm{~Hz}, \mathrm{H}_{\mathrm{A}}\right)$, $1.96\left(\mathrm{ddd}, 1 \mathrm{H}, J_{\mathrm{D}-\mathrm{B}}=8.5, J_{\mathrm{D}-\mathrm{C}}=5.4, J_{\mathrm{D}-\mathrm{A}}=4.3 \mathrm{~Hz}, \mathrm{H}_{\mathrm{D}}\right), 1.70\left(\mathrm{ddd}, 1 \mathrm{H}, J_{\mathrm{C}-\mathrm{A}}=9.2, J_{\mathrm{C}-\mathrm{D}}=5.1 \mathrm{~Hz},{ }^{2} J_{\mathrm{C}-\mathrm{B}}=5.1 \mathrm{~Hz}\right.$, $\left.\mathrm{H}_{\mathrm{C}}\right), 1.38\left(\mathrm{ddd}, 1 \mathrm{H}, J_{\mathrm{B}-\mathrm{D}}=8.6, J_{\mathrm{B}-\mathrm{A}}=6.4 \mathrm{~Hz},{ }^{2} J_{\mathrm{B}-\mathrm{C}}=4.9 \mathrm{~Hz}, \mathrm{H}_{\mathrm{B}}\right), 1.28 \mathrm{ppm}\left(\mathrm{t}, 3 \mathrm{H}, J=7.1 \mathrm{~Hz}, \mathrm{CH}_{3}\right) .{ }^{13} \mathbf{C} \mathbf{~ N M R}$ (100 MHz, $\left.\mathrm{CDCl}_{3}\right): \delta 172.6,148.5,142.4,132.7,129.4,121.5,120.9,61.02,25.4,24.5,17.1,14.2 \mathrm{ppm}$.

\section{Ethyl 2-(pentafluoro)phenylcyclopropane-1-carboxylate (5q)}<smiles>CCO[C@]1(C)[C@@H](C)[C@@]1(C)c1c(F)c(F)c(F)c(F)c1F</smiles>

Following procedure $\mathbf{A}$, trans isomer $\mathbf{5 q}$ was isolated as colorless oil. The analytical data are in accord with those reported in literature. ${ }^{[4]}$

${ }^{1} \mathbf{H}$ NMR (400 MHz, $\mathrm{CDCl}_{3}$ ): $\delta 4.18\left(\mathrm{q}, 2 \mathrm{H}, J=7.2 \mathrm{~Hz}, O \mathrm{CH}_{2}\right), 2.45-2.42\left(\mathrm{~m}, 1 \mathrm{H}, \mathrm{H}_{\mathrm{D}}\right), 2.15-2.12(\mathrm{~m}, 1 \mathrm{H}$, $\left.\mathrm{H}_{\mathrm{A}}\right), 1.60-1.58\left(\mathrm{~m}, 1 \mathrm{H}, \mathrm{CH}_{2}\right), 1.51-1.48\left(\mathrm{~m}, 1 \mathrm{H} \mathrm{CH}_{2}\right), 1.28 \mathrm{ppm}\left(\mathrm{t}, 3 \mathrm{H}, J=7.2 \mathrm{~Hz}, \mathrm{CH}_{3}\right) .{ }^{13} \mathbf{C} \mathbf{~ N M R}(100$ $\left.\mathrm{MHz}, \mathrm{CDCl}_{3}\right): \delta 172.7,164.0,61.1,20.9,15.0,14.7,14.2 \mathrm{ppm}$. Quaternary carbon atoms were not detectable. ${ }^{19}$ F NMR (376 MHz, CDCl3): $\delta-162.8\left(\mathrm{dd}, 2 \mathrm{~F}, J_{\mathrm{FF}}=21.5 \mathrm{~Hz},{ }^{4} J_{\mathrm{FF}}=7.7 \mathrm{~Hz}, \mathrm{~F}_{\text {ortho }}\right),-156.8(\mathrm{t}, 1 \mathrm{~F}$, $\left.J_{\mathrm{FF}}=20.9 \mathrm{~Hz}, \mathrm{~F}_{\mathrm{para}}\right),-143.8\left(\mathrm{ddd}, 2 \mathrm{~F}, J_{\mathrm{FF}}=21.8,21.5 \mathrm{~Hz},{ }^{4} J_{\mathrm{FF}}=7.6 \mathrm{~Hz}, \mathrm{~F}_{\text {ortho }}\right)$.

\section{Ethyl 2-(4-sulfamoylphenyl)cyclopropanecarboxylate (5r)}

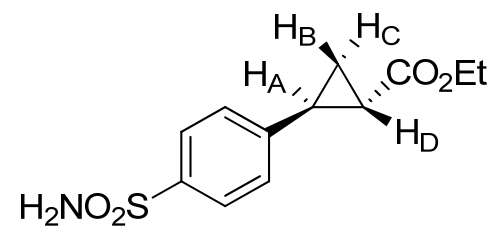

Performing the enzymatic reaction in $4 \mathrm{~mL}$-scale, trans isomer $\mathbf{5 r}$ was isolated as colorless oil.

${ }^{1}$ H NMR $\left(500 \mathrm{MHz}, \mathrm{CDCl}_{3}\right): \delta 7.81\left(\mathrm{~d}, 2 \mathrm{H}, J=8.4 \mathrm{~Hz}, \mathrm{H}_{\mathrm{Ar}}\right), 7.21\left(\mathrm{~d}, 2 \mathrm{H}, \mathrm{J}=8.4 \mathrm{~Hz}, \mathrm{H}_{\mathrm{Ar}}\right), 4.75\left(\mathrm{~s}, 2 \mathrm{H}, N \mathrm{H}_{2}\right)$, $4.16\left(\mathrm{q}, 2 \mathrm{H}, J=7.1 \mathrm{~Hz}, O \mathrm{CH}_{2}\right), 2.56\left(\mathrm{ddd}, 1 \mathrm{H}, J_{\mathrm{A}-\mathrm{C}}=9.3, J_{\mathrm{A}-\mathrm{B}}=6.3, J_{\mathrm{A}-\mathrm{D}}=4.2 \mathrm{~Hz}, \mathrm{H}_{\mathrm{A}}\right), 1.94\left(\mathrm{ddd}, 1 \mathrm{H}, J_{\mathrm{D}-\mathrm{B}}=8.8\right.$, $\left.J_{\mathrm{D}-\mathrm{C}}=5.4, J_{\mathrm{D}-\mathrm{A}}=4.3 \mathrm{~Hz}, \mathrm{H}_{\mathrm{D}}\right), 1.66\left(\mathrm{ddd}, 1 \mathrm{H}, J_{\mathrm{C}-\mathrm{A}}=9.5, J_{\mathrm{C}-\mathrm{D}}=5.1 \mathrm{~Hz},{ }^{2} J_{\mathrm{C}-\mathrm{B}}=5.1 \mathrm{~Hz}, \mathrm{H}_{\mathrm{C}}\right), 1.33\left(\mathrm{ddd}, 1 \mathrm{H}, J_{\mathrm{B}-}\right.$ $\left.\mathrm{D}=8.5, J_{\mathrm{B}-\mathrm{A}}=6.4 \mathrm{~Hz},{ }^{2} J_{\mathrm{B}-\mathrm{C}}=4.9 \mathrm{~Hz}, \mathrm{H}_{\mathrm{B}}\right) 1.27 \mathrm{ppm}\left(\mathrm{t}, 3 \mathrm{H}, J=7.1 \mathrm{~Hz}, \mathrm{CH}_{3}\right) .{ }^{13} \mathbf{C} \mathbf{N M R}\left(125 \mathrm{MHz}, \mathrm{CDCl}_{3}\right): \delta$ $127.52,127,47,61.7,26.4,25.5,18.2,15$ ppm. Quaternary carbon atoms were not detectable. 


\section{Ethyl 2-phenyl cyclopropane-1,2-dicarboxylate (5s)}<smiles>CCO[C@H]1[C@@H](C(=O)Oc2ccccc2)C1(C)C</smiles>

Following procedure A, trans isomer $\mathbf{5 s}$ was isolated as colorless oil. The analytical data are in accord with those reported in literature. ${ }^{[9]}$

${ }^{1}$ H NMR $\left(500 \mathrm{MHz}, \mathrm{CDCl}_{3}\right): \delta 7.38\left(\mathrm{t}, 2 \mathrm{H}, J=7.4 \mathrm{~Hz}, \mathrm{H}_{\mathrm{Ar}}\right), 7.27-7.23\left(\mathrm{~m}, 1 \mathrm{H}, \mathrm{H}_{\mathrm{Ar}}\right), 7.10(\mathrm{~d}, 2 \mathrm{H}, J=8.4 \mathrm{~Hz}$, $\left.\mathrm{H}_{\mathrm{Ar}}\right), 4.20\left(\mathrm{q}, 2 \mathrm{H}, J=7.1 \mathrm{~Hz}, O \mathrm{CH}_{2}\right), 2.44-2.37(\mathrm{~m}, 1 \mathrm{H}), 2.36-2.29(\mathrm{~m}, 1 \mathrm{H}), 1.60-1.56\left(\mathrm{~m}, 2 \mathrm{H}, \mathrm{CH}_{2}\right), 1.31$ $\operatorname{ppm}\left(\mathrm{t}, 3 \mathrm{H}, J=7.1 \mathrm{~Hz}, \mathrm{CH}_{3}\right) .{ }^{13} \mathbf{C} \mathbf{N M R}\left(125 \mathrm{MHz} \mathrm{CDCl}_{3}\right): \delta 171.5,170.4,150.4,129.4,125.9,121.3,61.2$, 23.0, 22.2, 15.9, $14.2 \mathrm{ppm}$.

\section{1-Benzyl 2-ethyl cyclopropane-1,2-dicarboxylate (5t)}<smiles>CCO[C@]1(C)[C@@H](C)[C@]1(C)C(=O)OCc1ccccc1</smiles>

Following procedure $\mathbf{A}$, trans isomer $\mathbf{5 t}$ was isolated as colorless oil. The analytical data are in accord with those reported in literature. ${ }^{[10]}$

${ }^{1} \mathbf{H}$ NMR (500 MHz, $\left.\mathrm{CDCl}_{3}\right): \delta$ 7.37-7.31 (m, 5H, Har), $5.13\left(\mathrm{~s}, 2 \mathrm{H}, \mathrm{CH}_{2}\right), 4.14\left(\mathrm{q}, 2 \mathrm{H}, J=7.1 \mathrm{~Hz}, \mathrm{OCH}_{2}\right)$, 2.25-2.17 (m, 2H, CH and $\mathrm{CH}), 1.46\left(\mathrm{~m}, 2 \mathrm{H}, \mathrm{CH}_{2}\right), 1.26 \mathrm{ppm}\left(\mathrm{t}, 3 \mathrm{H}, J=7.1 \mathrm{~Hz}, \mathrm{CH}_{3}\right) .{ }^{13} \mathbf{C} \mathbf{N M R}(125 \mathrm{MHz}$, $\left.\mathrm{CDCl}_{3}\right): \delta 171.8,135.6,128.8,128.5,67.0,61.3,22.7,22.5,15.7,14.3 \mathrm{ppm}$. Quaternary carbon atoms were not detected.

\section{2-(Ethoxycarbonyl)cyclopropyl benzoate (5u)}<smiles>CCO[C@H]1[C@@H](OC(=O)c2ccccc2)C1(C)C</smiles><smiles>CCOC(=O)[C@@H]1[C@@H](OC(=O)c2ccccc2)C1(C)C</smiles>

Following procedure $\mathbf{A}$, trans and cis isomer $\mathbf{5} \mathbf{u}$ was isolated as colorless oil.

GC-MS $m / z$ (\% relative intensity): 222 (49.5), 176 (36.7), 149 (100), 134 (26.7), 116 (70.0), 109 (30.6). trans 5u: ${ }^{1} \mathbf{H}$ NMR (400 MHz, $\left.\mathrm{CDCl}_{3}\right): \delta 7.98\left(\mathrm{~d}, 2 \mathrm{H}, J=7.2 \mathrm{~Hz}, \mathrm{H}_{\mathrm{Ar}}\right), 7.56\left(\mathrm{t}, 1 \mathrm{H}, J=7.4 \mathrm{~Hz}, \mathrm{H}_{\mathrm{Ar}}\right), 7.43(\mathrm{t}$, $\left.2 \mathrm{H}, J=7.8 \mathrm{~Hz}, \mathrm{H}_{\mathrm{Ar}}\right), 4.65\left(\mathrm{ddd}, 1 \mathrm{H}, J_{\mathrm{A}-\mathrm{C}}=6.6, J_{\mathrm{A}-\mathrm{B}}=4.2, J_{\mathrm{A}-\mathrm{D}}=2.2 \mathrm{~Hz}, \mathrm{H}_{\mathrm{A}}\right), 4.17\left(\mathrm{q}, 2 \mathrm{H}, J=7.1 \mathrm{~Hz}, O \mathrm{CH}_{2}\right)$, $2.01\left(\mathrm{ddd}, 1 \mathrm{H}, J_{\mathrm{D}-\mathrm{B}}=9.8, J_{\mathrm{D}-\mathrm{C}}=6.3, J_{\mathrm{D}-\mathrm{A}}=2.2 \mathrm{~Hz}, \mathrm{H}_{\mathrm{D}}\right), 1.53\left(\mathrm{ddd}, 1 \mathrm{H}, J_{\mathrm{C}-\mathrm{A}}=6.4, J_{\mathrm{C}-\mathrm{D}}=6.4 \mathrm{~Hz},{ }^{2} J_{\mathrm{C}-\mathrm{B}}=6.4 \mathrm{~Hz}\right.$, 
$\left.\mathrm{CH}_{\mathrm{C}}\right), 1.42\left(\mathrm{ddd}, 1 \mathrm{H}, J_{\mathrm{B}-\mathrm{D}}=10.1, J_{\mathrm{B}-\mathrm{A}}=4.3 \mathrm{~Hz},{ }^{2} J_{\mathrm{B}-\mathrm{C}}=6.1 \mathrm{~Hz}, \mathrm{H}_{\mathrm{B}}\right), 1.28 \mathrm{ppm}\left(\mathrm{t}, 3 \mathrm{H}, J=7.1 \mathrm{~Hz}, \mathrm{CH}_{3}\right) .{ }^{13} \mathbf{C} \mathbf{N M R}$ $\left(125 \mathrm{MHz}, \mathrm{CDCl}_{3}\right): \delta 228.9,171.7,166.7,133.5,129.7,128.6,61.1,54.9,20.8,14.4,14.3 \mathrm{ppm}$.

cis $5 u$ : ${ }^{1} \mathbf{H}$ NMR (400 MHz, $\left.\mathrm{CDCl}_{3}\right): \delta 8.01\left(\mathrm{~d}, 2 \mathrm{H}, J=7.2 \mathrm{~Hz}, \mathrm{H}_{\mathrm{Ar}}\right), 7.55\left(\mathrm{t}, 1 \mathrm{H}, J=7.4 \mathrm{~Hz}, \mathrm{H}_{\mathrm{Ar}}\right), 7.42(\mathrm{t}, 2 \mathrm{H}$, $\left.J=7.8 \mathrm{~Hz}, \mathrm{H}_{\mathrm{Ar}}\right), 4.51\left(\mathrm{ddd}, 1 \mathrm{H}, J_{\mathrm{A}-\mathrm{C}}=6.9, J_{\mathrm{A}-\mathrm{B}}=4.9, J_{\mathrm{A}-\mathrm{D}}=6.9 \mathrm{~Hz}, \mathrm{H}_{\mathrm{A}}\right), 4.11\left(\mathrm{q}, 2 \mathrm{H}, J=7.1 \mathrm{~Hz}, O \mathrm{CH}_{2}\right), 2.06$ $\left(\mathrm{ddd}, 1 \mathrm{H}, J_{\mathrm{D}-\mathrm{C}}=8.7, J_{\mathrm{D}-\mathrm{B}}=7.1, J_{\mathrm{D}-\mathrm{A}}=7.0 \mathrm{~Hz}, \mathrm{H}_{\mathrm{D}}\right), 1.53\left(\mathrm{ddd}, 1 \mathrm{H}, J_{\mathrm{B}-\mathrm{D}}=6.7, J_{\mathrm{B}-\mathrm{A}}=4.8 \mathrm{~Hz},{ }^{2} J_{\mathrm{B}-\mathrm{C}}=6.7 \mathrm{~Hz}, \mathrm{H}_{\mathrm{B}}\right)$, $1.42\left(\mathrm{ddd}, 1 \mathrm{H}, J_{\mathrm{C}-\mathrm{D}}=8.7, J_{\mathrm{C}-\mathrm{A}}=6.7 \mathrm{~Hz},{ }^{2} J_{\mathrm{C}-\mathrm{B}}=6.7 \mathrm{~Hz}, \mathrm{H}_{\mathrm{C}}\right), 1.28 \mathrm{ppm}\left(\mathrm{t}, 3 \mathrm{H}, J=7.1 \mathrm{~Hz}, \mathrm{CH}_{3}\right) .{ }^{13} \mathbf{C} \mathbf{~ N M R}(125$ $\left.\mathrm{MHz}, \mathrm{CDCl}_{3}\right): \delta 169.5,167.1,133.4,129.8,128.5,61.0,53.1,20.2,14.3,12.4 \mathrm{ppm}$. Quaternary carbon atom was not detectable.

\section{Ethyl 2-(2-oxopyrrolidin-1-yl) cyclopropane-1-carboxylate (5v)}

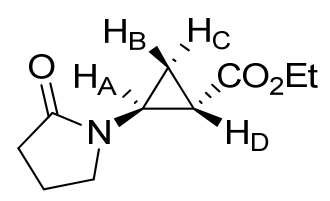

Following procedure $\mathbf{C}$, trans isomer $\mathbf{5 v}$ was isolated as yellow oil (37\% yield). The analytical data are in accord with those reported in literature. ${ }^{[1]}$

${ }^{1} \mathbf{H}$ NMR $\left(500 \mathrm{MHz}, \mathrm{CDCl}_{3}\right): \delta 4.05\left(\mathrm{qd}, 2 \mathrm{H}, J=7.2,2.3 \mathrm{~Hz}, O \mathrm{CH}_{2}\right), 3.23\left(\mathrm{t}, 2 \mathrm{H}, J=7.2 \mathrm{~Hz}, \mathrm{CH}_{2}\right.$ pyrrolidone), 3.09 (ddd, $\left.1 \mathrm{H}, J_{\mathrm{A}-\mathrm{C}}=8.2, J_{\mathrm{A}-\mathrm{B}}=5.3, J_{\mathrm{A}-\mathrm{D}}=3.1 \mathrm{~Hz}, \mathrm{H}_{\mathrm{A}}\right), 2.29\left(\mathrm{t}, 2 \mathrm{H}, J=8.0 \mathrm{~Hz}, \mathrm{CH}_{2}\right.$ pyrrolidone), 1.95-1.89 (m, 2H, $\mathrm{CH}_{2}$ pyrrolidone), $1.76\left(\mathrm{ddd}, 1 \mathrm{H}, J_{\mathrm{D}-\mathrm{B}}=9.1, J_{\mathrm{D}-\mathrm{C}}=5.9, J_{\mathrm{D}-\mathrm{A}}=3.1 \mathrm{~Hz}, \mathrm{H}_{\mathrm{D}}\right), 1.37(\mathrm{ddd}, 1 \mathrm{H}$, $\left.J_{\mathrm{C}-\mathrm{A}}=8.0, J_{\mathrm{C}-\mathrm{D}}=5.7 \mathrm{~Hz},{ }^{2} J_{\mathrm{C}-\mathrm{B}}=5.4 \mathrm{~Hz}, \mathrm{H}_{\mathrm{C}}\right), 1.32\left(\mathrm{ddd}, 1 \mathrm{H}, J_{\mathrm{B}-\mathrm{D}}=9.2, J_{\mathrm{B}-\mathrm{A}}=5.4 \mathrm{~Hz},{ }^{2} J_{\mathrm{B}-\mathrm{C}}=5.4 \mathrm{~Hz}, \mathrm{H}_{\mathrm{B}}\right), 1.18 \mathrm{ppm}$ $\left(\mathrm{t}, 3 \mathrm{H}, J=7.1 \mathrm{~Hz}, \mathrm{CH}_{3}\right) .{ }^{13} \mathbf{C}$ NMR $\left(125 \mathrm{MHz}, \mathrm{CDCl}_{3}\right): \delta 175.9,172.3,60.9,47.2,34.1,31.7,19.7,18.0$, $14.2,14.1 \mathrm{ppm}$.

\section{Ethyl 2-(1,3-dioxoisoindolin-2-yl)cyclopropanecarboxylate2-(phenoxymethyl)cyclopropane-1- carboxylate (5w)}

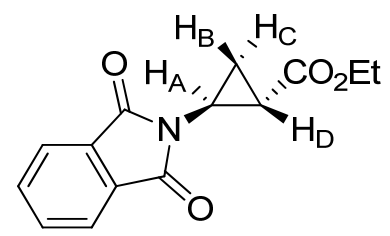

Following procedure $\mathbf{A}$, trans isomer $\mathbf{5 w}$ was isolated as colorless oil. The analytical data are in accord with those reported in literature. ${ }^{[12]}$

${ }^{1} \mathbf{H}$ NMR (500 MHz, $\left.\mathrm{CDCl}_{3}\right): \delta 7.82\left(\mathrm{dd}, 2 \mathrm{H}, J=5.5,3.0 \mathrm{~Hz}, \mathrm{H}_{\mathrm{Ar}}\right), 7.72\left(\mathrm{dd}, 2 \mathrm{H}, J=5.5,3.0 \mathrm{~Hz}, \mathrm{H}_{\mathrm{Ar}}\right), 4.20$ $\left(\mathrm{q}, 2 \mathrm{H}, J=7.2 \mathrm{~Hz}, O \mathrm{OCH}_{2}\right), 3.30\left(\mathrm{ddd}, 1 \mathrm{H}, J_{\mathrm{A}-\mathrm{C}}=8.2, J_{\mathrm{A}-\mathrm{B}}=5.2, J_{\mathrm{A}-\mathrm{D}}=3.1 \mathrm{~Hz}, \mathrm{H}_{\mathrm{A}}\right), 2.21\left(\mathrm{ddd}, 1 \mathrm{H}, J_{\mathrm{D}-\mathrm{B}}=9.3, J_{\mathrm{D}-}\right.$ $\left.\mathrm{C}_{\mathrm{C}}=6.2, J_{\mathrm{D}-\mathrm{A}}=3.2 \mathrm{~Hz}, \mathrm{H}_{\mathrm{D}}\right), 1.75\left(\mathrm{ddd}, 1 \mathrm{H}, J_{\mathrm{B}-\mathrm{D}}=9.3, J_{\mathrm{B}-\mathrm{A}}=5.2 \mathrm{~Hz},{ }^{2} J_{\mathrm{B}-\mathrm{C}}=5.7 \mathrm{~Hz}, \mathrm{H}_{\mathrm{B}}\right), 1.63\left(\mathrm{ddd}, 1 \mathrm{H}, J_{\mathrm{C}-\mathrm{A}}=8.1\right.$, 
$\left.J_{\mathrm{C}-\mathrm{D}}=6.2 \mathrm{~Hz},{ }^{2} J_{\mathrm{C}-\mathrm{B}}=5.8 \mathrm{~Hz}, \mathrm{H}_{\mathrm{C}}\right), 1.30 \mathrm{ppm}\left(\mathrm{t}, 3 \mathrm{H}, J=7.1 \mathrm{~Hz}, \mathrm{CH}_{3}\right) .{ }^{13} \mathbf{C} \mathbf{N M R}\left(125 \mathrm{MHz}, \mathrm{CDCl}_{3}\right): \delta 172.26$, $168.16,134.37,131.65,123.48,61.23,29.61,20.09,14.35,13.69$ ppm. 


\section{NMR Spectra}

Ethyl 2-(4-sulfamoylphenyl)cyclopropanecarboxylate (5r)

${ }^{1} \mathbf{H}$ NMR $\left(500 \mathrm{MHz}, \mathrm{CDCl}_{3}\right)$
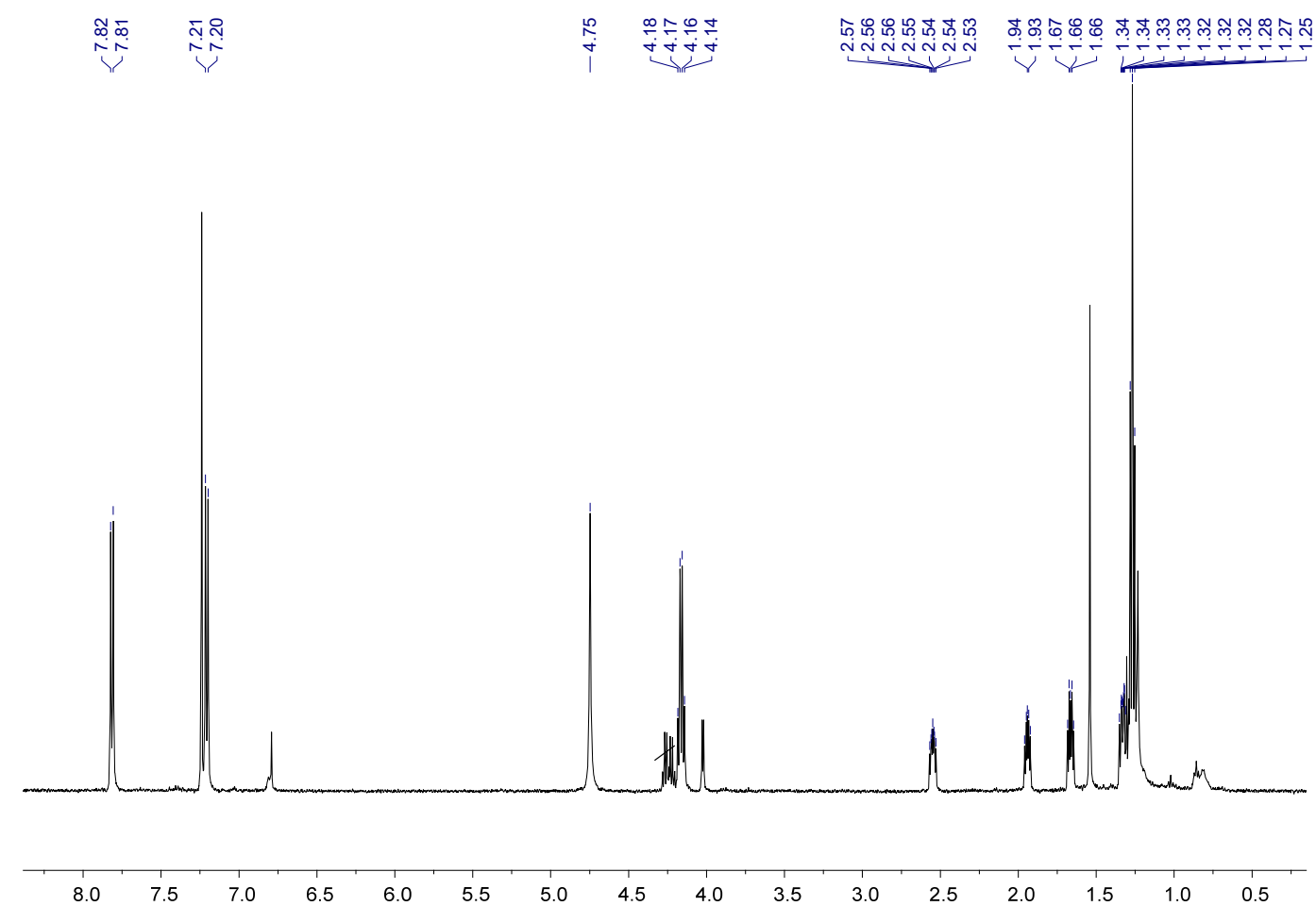

${ }^{13} \mathbf{C}$ NMR (125 MHz, $\left.\mathrm{CDCl}_{3}\right)$
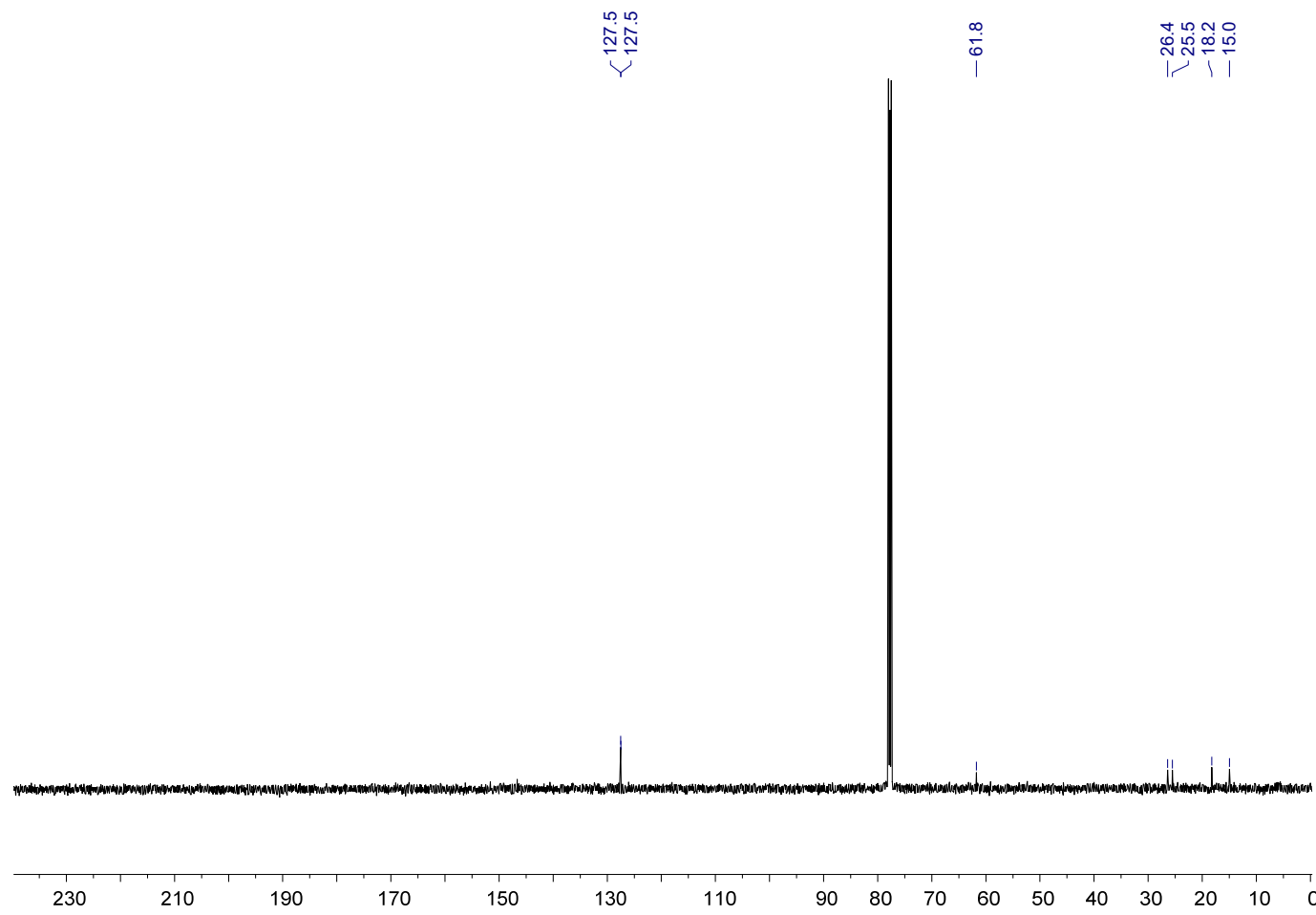

170 
trans 2-(Ethoxycarbonyl)cyclopropyl benzoate (5u)

${ }^{1} \mathbf{H}$ NMR $\left(400 \mathrm{MHz}, \mathrm{CDCl}_{3}\right)$

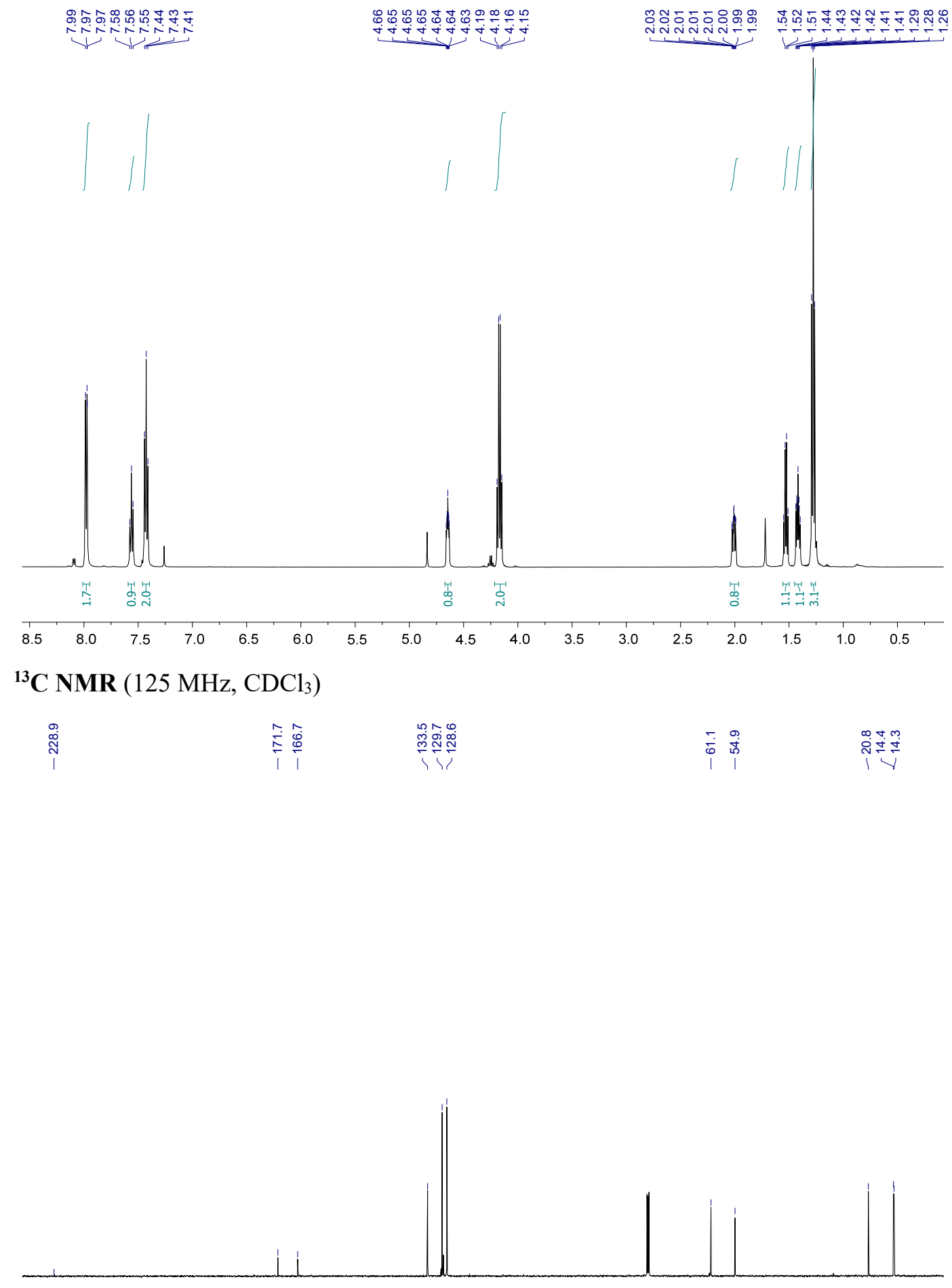

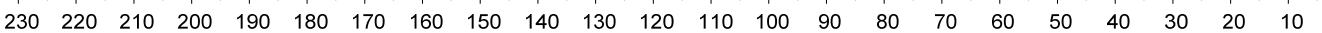


cis 2-(Ethoxycarbonyl)cyclopropyl benzoate (5u)

${ }^{\mathbf{1}} \mathbf{H}$ NMR (500 MHz, $\mathrm{CDCl}_{3}$ )

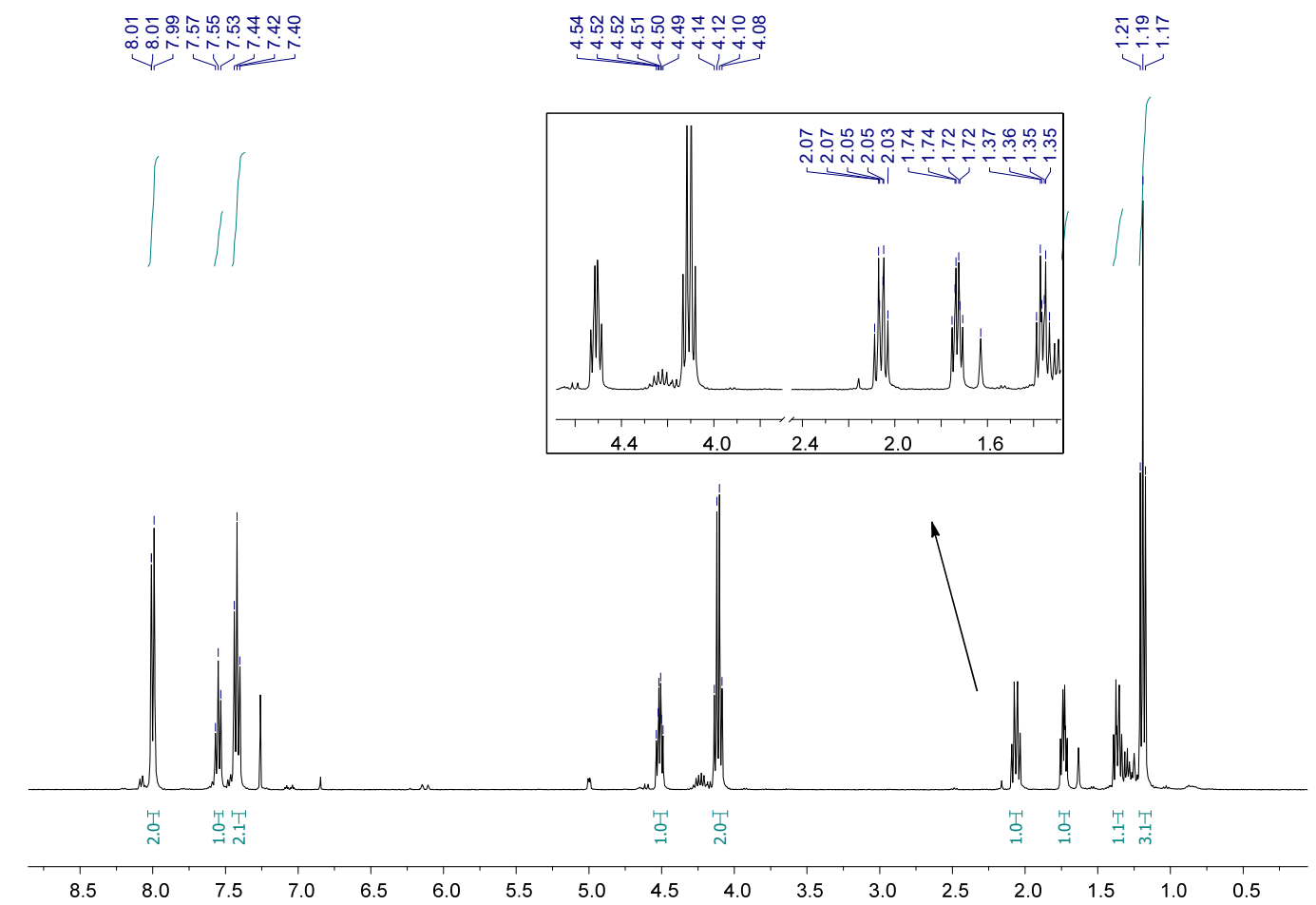

${ }^{13} \mathbf{C}$ NMR (125 MHz, $\left.\mathrm{CDCl}_{3}\right)$
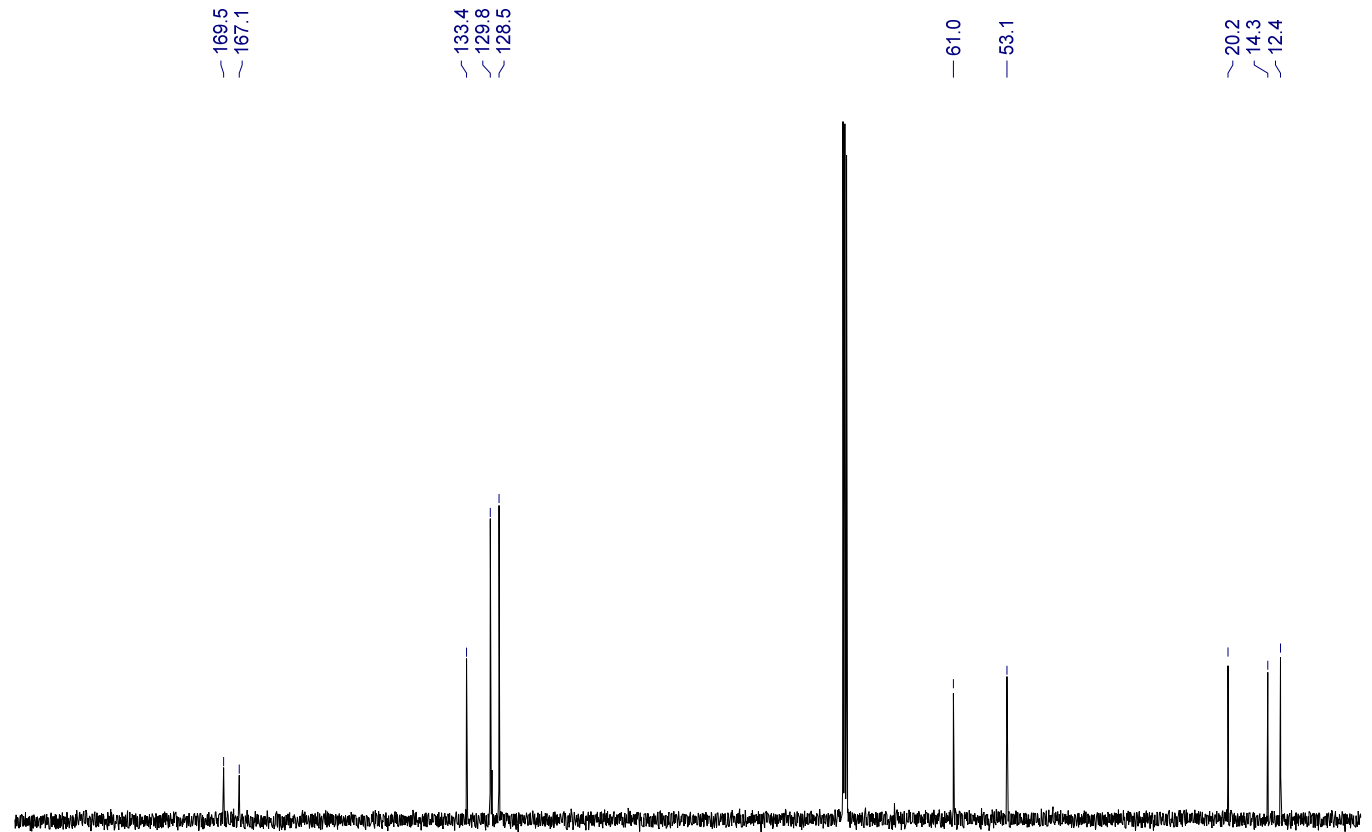

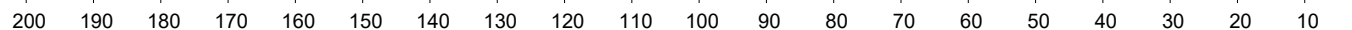


${ }^{2} \mathrm{H}-\mathrm{NMR}$ spectra indicating mixture of $d-5 \mathbf{a}_{\text {cis }}$ and $d-5 \mathrm{a}_{\text {trans }}$ diastereomers produced from Mb(H64V,V68A,H93NMH)[Fe(DADP)]

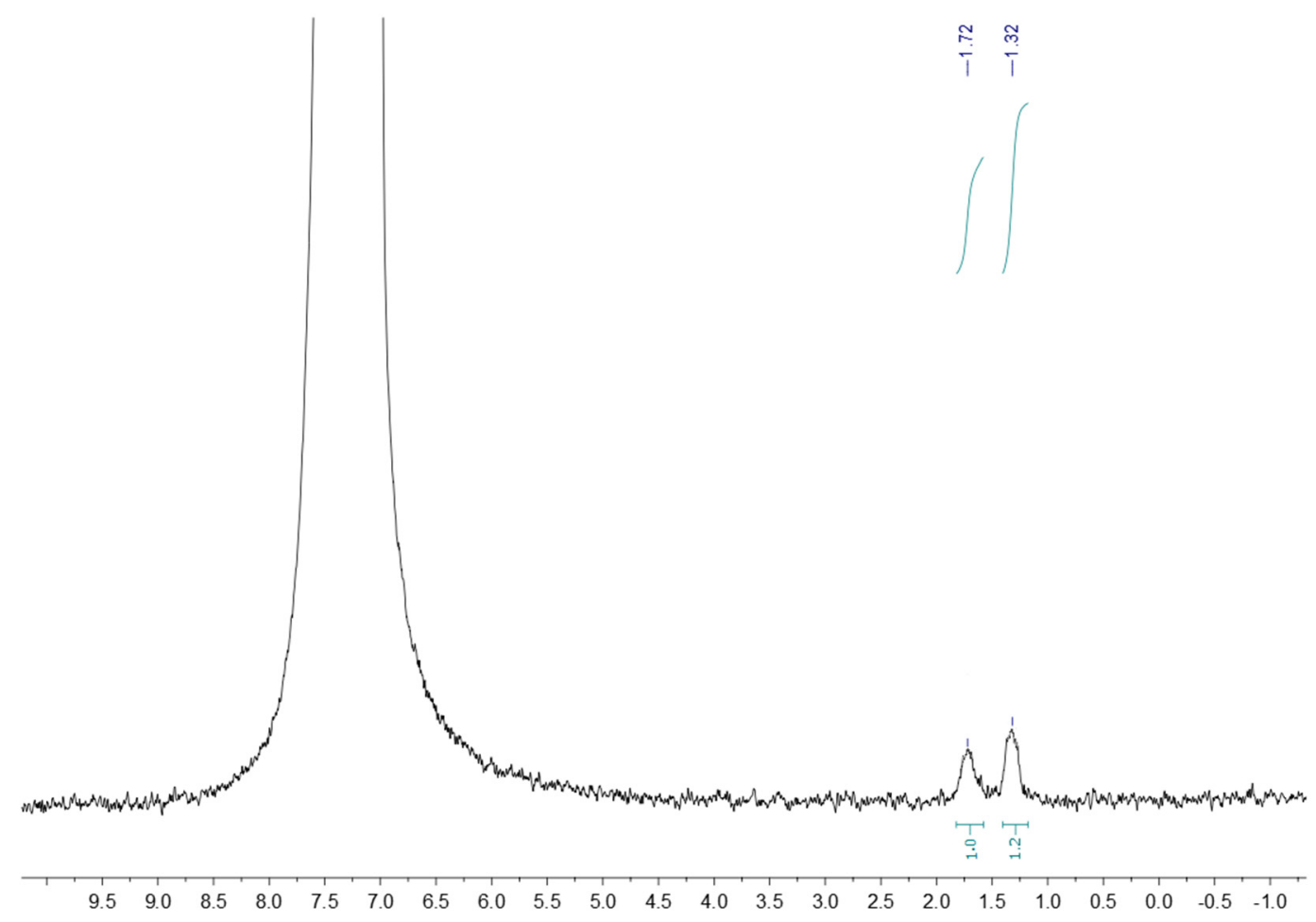




\section{References:}

[1] P. Bajaj, G. Sreenilayam, V. Tyagi, R. Fasan, Angew. Chem. Int. Ed. 2016, 55, 1611016114.

[2] Y. Wei, A. Tinoco, V. Steck, R. Fasan, Y. Zhang, J. Am. Chem. Soc. 2018, 140, 16491662.

[3] M. Bordeaux, V. Tyagi, R. Fasan, Angew. Chem. Int. Ed. 2015, 54, 1744-1748.

[4] Y. Chen, X. P. Zhang, J. Org. Chem. 2007, 72, 5931-5934.

[5] G. Sreenilayam, E. J. Moore, V. Steck, R. Fasan, ACS Catal. 2017, 7, 7629-7633.

[6] A. Tinoco, Y. Wei, J.-P. Bacik, D. M. Carminati, E. J. Moore, N. Ando, Y. Zhang, R. Fasan, ACS Catal. 2019, 9, 1514-1524.

[7] C. Binda, S. Valente, M. Romanenghi, S. Pilotto, R. Cirilli, A. Karytinos, G. Ciossani, O. A. Botrugno, F. Forneris, M. Tardugno, D. E. Edmondson, S. Minucci, A. Mattevi, A. Mai, J. Am. Chem. Soc. 2010, 132, 6827-6833.

[8] B. Morandi, A. Dolva, E. M. Carreira, Org. Lett. 2012, 14, 2162-2163.

[9] V. K. Aggarwal, H. W. Smith, G. Hynd, R. V. H. Jones, R. Fieldhouse, S. E. Spey, J. Chem. Soc., Perkin Transac. 1 2000, 3267-3276.

[10] A. M. Knight, S. B. J. Kan, R. D. Lewis, O. F. Brandenberg, K. Chen, F. H. Arnold, ACS Centr. Sci. 2018, 4, 372-377.

[11] F. de Nanteuil, J. Waser, Angew. Chem. Int. Ed. 2011, 50, 12075-12079.

[12] O. F. Brandenberg, C. K. Prier, K. Chen, A. M. Knight, Z. Wu, F. H. Arnold, ACS Catal. 2018, 8, 2629-2634. 